UNIVERSIDADE DE SÃO PAULO

ESCOLA DE ENGENHARIA DE SÃO CARLOS

CENTRO DE RECURSOS HÍDRICOS E ECOLOGIA APLICADA

PÓS-GRADUAÇÃO EM CIÊNCIAS DA ENGENHARIA AMBIENTAL

JOÃO MARCOS VILLELA

AVALIAÇÃO DA INFLUÊNCIA DA EXPANSÃO DA CANA-DE-AÇÚCAR NO REGIME HIDROSSEDIMENTOLÓGICO NA MICROBACIA DO CÓRREGO CANA DO REINO, VOTUPORANGA - SP.

São Carlos 


\section{AVALIAÇÃO DA INFLUÊNCIA DA EXPANSÃO DA CANA-DE-AÇÚCAR NO REGIME HIDROSSEDIMENTOLÓGICO NA MICROBACIA DO CÓRREGO CANA DO REINO, VOTUPORANGA - SP.}

Dissertação apresentada à Escola de Engenharia de São Carlos, da Universidade de São Paulo, como parte dos requisitos para obtenção do título de mestre em Ciências da Engenharia Ambiental

Orientador: Prof. Dr. Frederico Fábio Mauad

VERSÃO CORRIGIDA

São Carlos 
AUTORIZO A REPRODUÇÄO TOTAL OU PARCIAL DESTE TRABALHO, POR QUALQUER MEIO CONVENCIONAL OU ELETRÔNICO, PARA FINS DE ESTUDO E PESQUISA, DESDE QUE CITADA A FONTE.

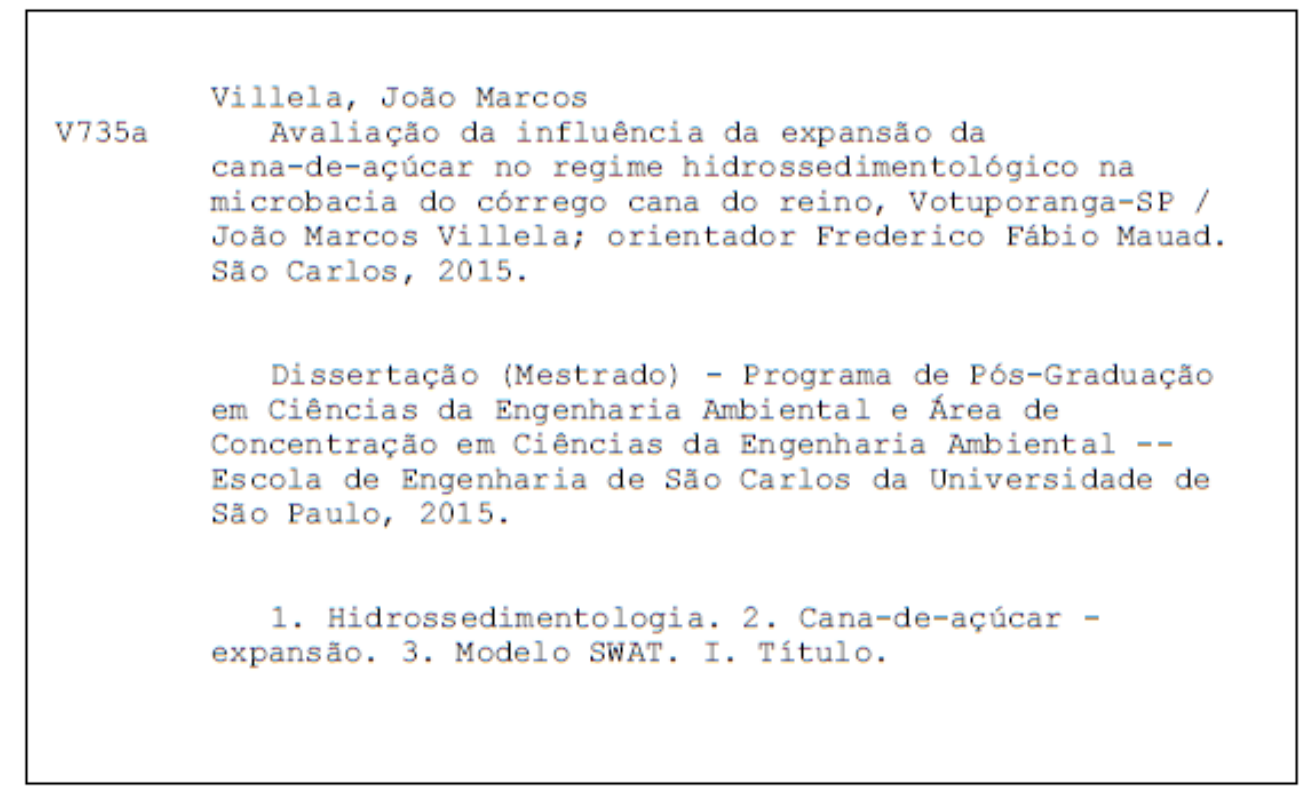




\section{FOLHA DE JULGAMENTO}

Candidato: Bacharel JOÃO MARCOS VILLELA.

Título da dissertação: "Avaliação da influência da expansão da cana-de-açúcar no regime hidrossedimentológico na microbacia do córrego Cana do Reino, Votuporanga - SP".

Data da defesa: 29/04/2015

\section{Comissão Julgadora:}

Resultado:

Prof. Associado Frederico Fábio Mauad (Orientador Substituto)

(Escola de Engenharia de São Carlos/EESC)

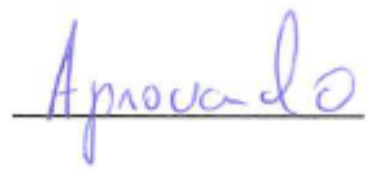

Dr. Silvio Crestana

(Empresa Brasileira de Pesquisa Agropecuária/EMBRAPA-São Carlos)

Dr. Júlio César Pascale Palhares

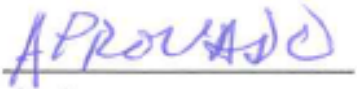

(Empresa Brasileira de Pesquisa Agropecuária/EMBRAPA-São Carlos)

Coordenador do Programa de Pós-Graduação em Ciência da Engenharia Ambiental Prof. Associado Frederico Fábio Mauad

Presidente da Comissão de Pós-Graduação:

Prof. Associado Paulo Sergio Lima Segantine 
Dedico este trabalho especialmente:

Aos meus pais, Hélio e Angela.

Aos meus irmãos, Paulo e Mário e, À minha namorada Laura. 


\section{AGRADECIMENTOS}

Agradeço:

\section{À Deus}

Ao meu orientador professor Dr. Frederico Fábio Mauad, meus sinceros agradecimentos pelos ensinamentos, confiança, paciência e pela orientação.

Ao Núcleo de Hidrometria do Centro de Recursos Hídricos e Ecologia Aplicada da Escola de Engenharia de São Carlos (USP), por todo suporte oferecido durante a realização deste trabalho, incluindo todos os funcionários do CRHEA. Muito obrigado!

À CAPES, pela bolsa de estudo e pelo suporte financeiro para viabilização desta pesquisa.

Aos meus pais e irmãos, pelo apoio e carinho recebido durante todo o meu trabalho.

À minha namorada Laura, por todo o amor, dedicação e paciência.

Ao professor Dr. Silvio Crestana e ao pesquisador Dr. Júlio Palhares pela participação e por todas as sugestões e considerações feitas no exame de qualificação e também na defesa deste trabalho.

A Empresa Athenas Consultoria Agrícola e Laboratório-Jaboticabal-SP, pela colaboração na análise dos solos, de grande importância para a realização deste trabalho.

Aos amigos do Núcleo de Hidrometria, Renato, Bruno, Marcus, Paulo, Claudio, Raphael, Francine, Dalva e Miro, pelo companheirismo e sugestões para este trabalho.

Muito obrigado! 


\section{SUMÁRIO}

RESUMO

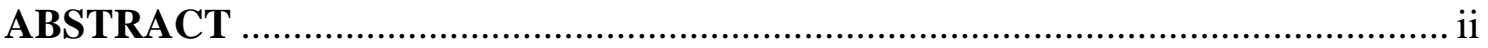

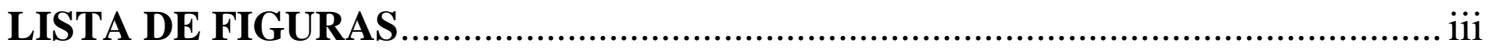

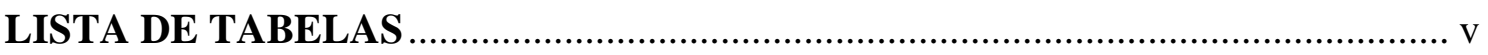

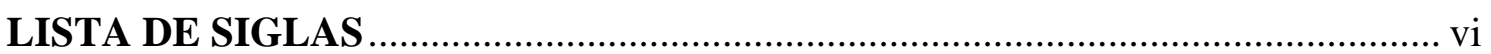

1. INTRODUÇÃ

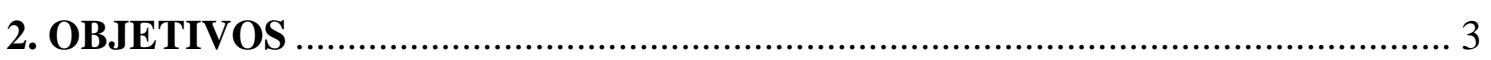

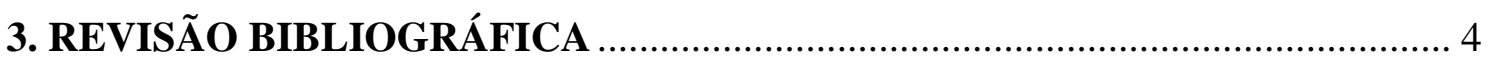

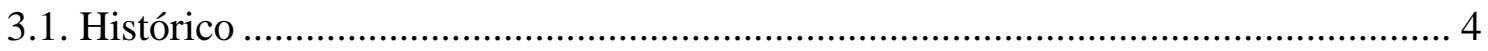

3.2. Expansão da cana-de-açúcar no Estado de São Paulo ............................................... 11

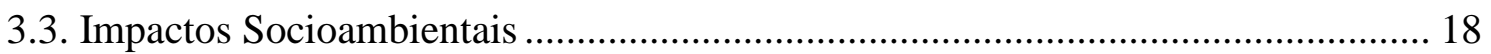

3.4. Produção de sedimentos em Bacias hidrográficas................................................ 23

3.5 Modelos Preditivos de Erosão ............................................................................. 25

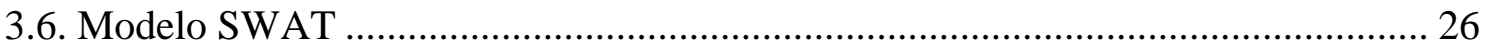

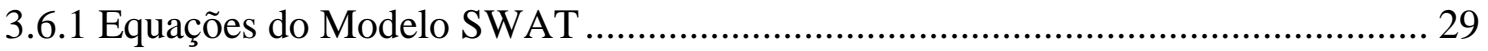

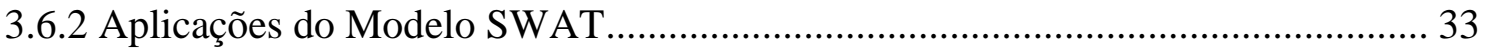

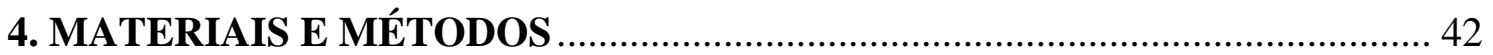

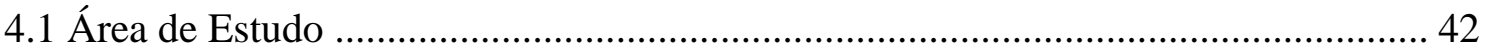

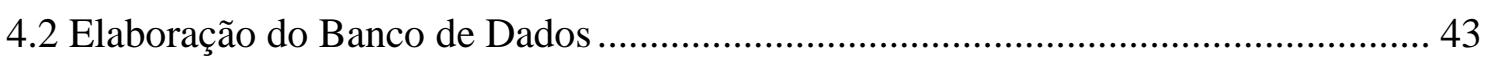

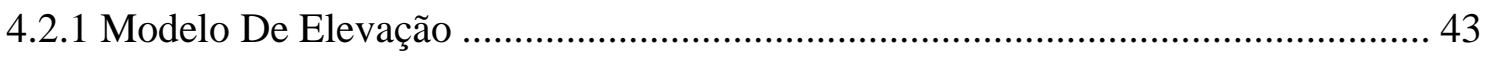

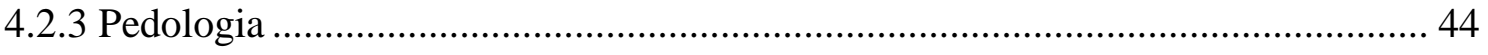

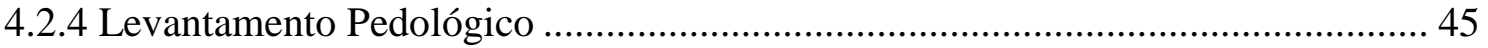

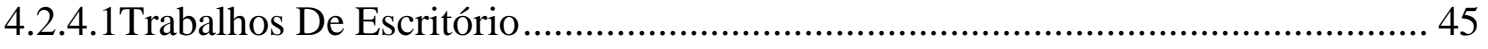

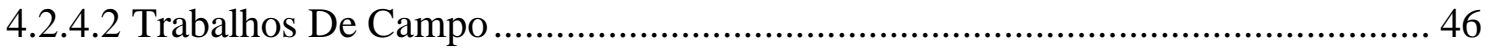

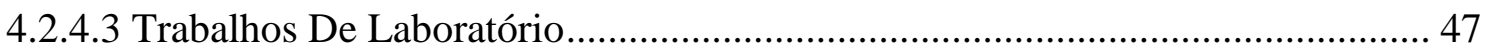

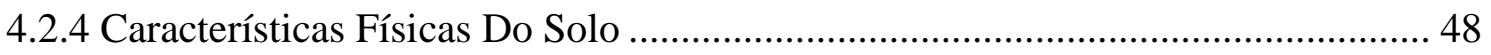

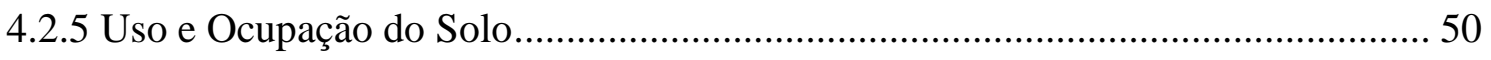

4.2.5.1 Dados Tabulares de Uso do Solo....................................................................... 52

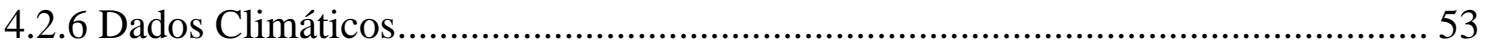

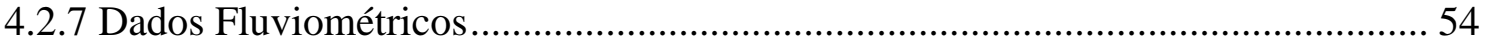

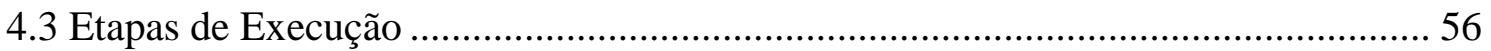




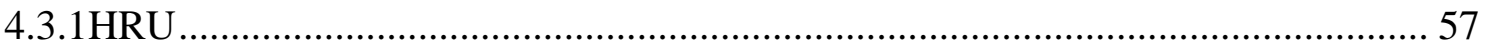

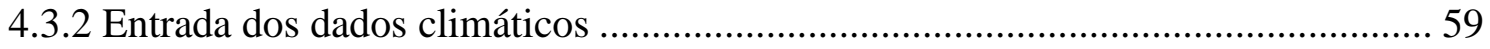

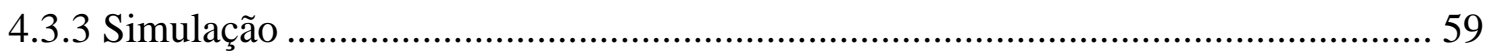

4.3.4 Análise de Sensibilidade Calibração e Verificação ............................................. 60

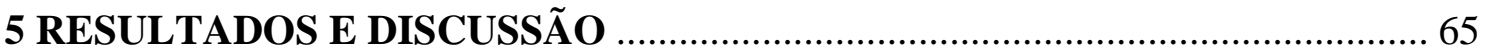

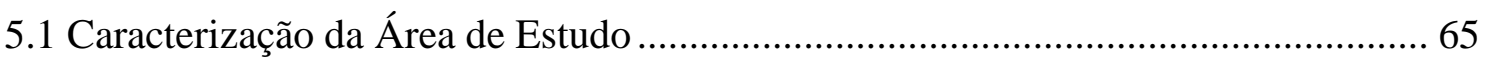

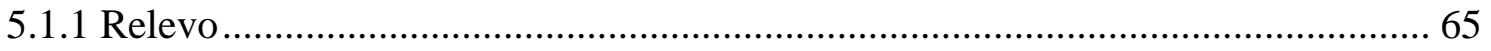

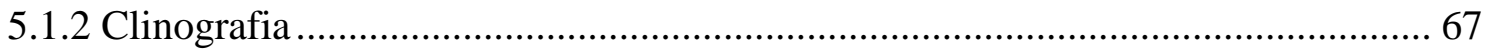

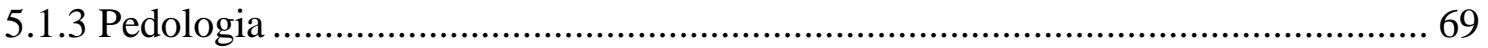

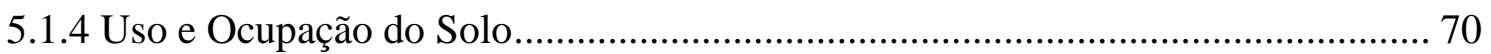

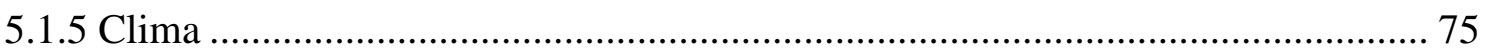

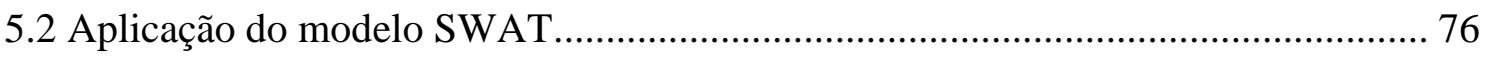

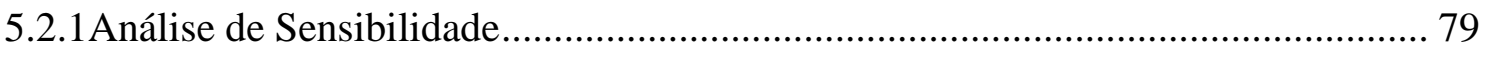

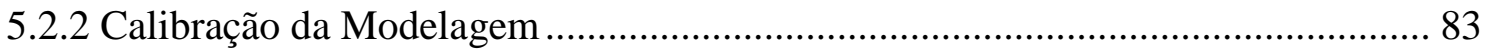

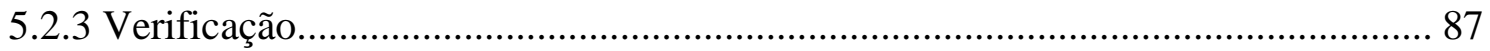

5.3 Análise comparativa entre os cenários de 2005 e 2014 ......................................... 91

5.3.1 Avaliação das estimativas de produção de sedimentos ...................................... 106

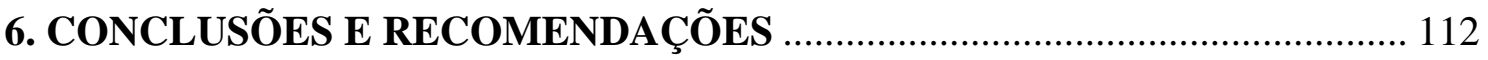

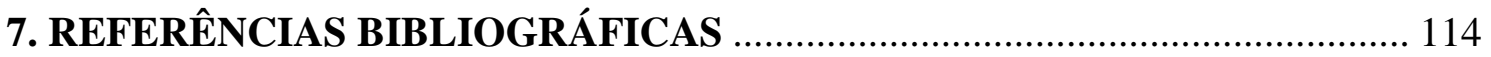

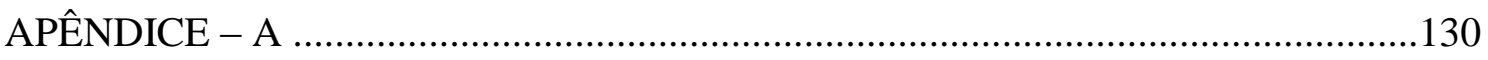

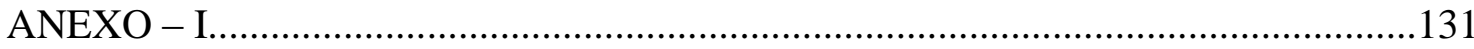

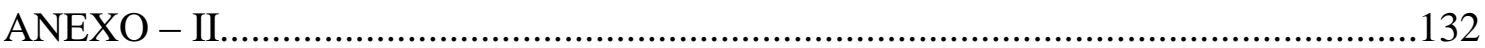




\section{RESUMO}

VILLELA, J.M. Avaliação da influência da expansão da cana-de-açúcar no regime hidrossedimentológico na microbacia do córrego Cana do Reino, Votuporanga - SP. 2015. 132 p. Dissertação (Mestrado) - Escola de Engenharia de São Carlos, Universidade de São Paulo, São Carlos, 2011.

A expansão do cultivo de cana-de-açúcar motivada pelo aumento na demanda por etanol após lançamento da tecnologia fex fuel, resultou em grandes transformações na paisagem. O estado de São Paulo absorveu boa parte das áreas de expansão, que se instalaram em novas regiões do estado. A expansão ocorrida gera reflexões sobre os impactos ambientais negativos associados à cultura canavieira, sobretudo quanto às alterações no regime hidrossedimentológico das bacias hidrográficas. Neste contexto o presente estudo buscou avaliar a influência da expansão do cultivo da cana de açúcar sobre os aspectos hidrossedimentológicos (taxa de escorrimento superficial e produção de sedimento) em uma região onde houve um aumento significativo desta cultura. O local de estudo é a microbacia do córrego Cana do Reino, localizada no município de Votuporanga - SP. A avaliação se deu por meio de um comparativo entre as taxas de escorrimento e da produção de sedimentos para os cenários antes do período de expansão do cultivo desta cultura (2005) e após a expansão (2014), utilizando o Modelo SWAT. As simulações das vazões médias mensais apresentaram resultados satisfatórios após a calibração. Nesta etapa obtiveram-se valores para os coeficientes de eficiência de Nash-Sutcliffe (NSE), coeficiente de determinação $\left(R^{2}\right)$ e percentual de tendências (PBIAS) de respectivamente, 0,85, 0,82 e -1,5. Na validação observou-se valores de NSE, $\mathrm{R}^{2}$ e PBIAS, iguais a 0,76, 0,81 e -9,0, respectivamente. Nas simulações contatou-se que as taxas médias de escorrimento superficial e produção de sedimentos para o cenário de 2005 foram de $44 \mathrm{~mm}$ e 2,6 ton.ha ${ }^{-1}$.ano ${ }^{-1}$. Para o cenário de 2014 obteve-se $70 \mathrm{~mm}$ e 4,5 ton.ha ${ }^{-1}$.ano ${ }^{-1}$. A partir dos resultados obtidos, conclui-se que o Modelo SWAT demonstrou-se satisfatório para a análise comparativa entre os cenários.

Palavras-chave: Hidrossedimentologia, Cana-de-açúcar - expansão e Modelo SWAT. 


\begin{abstract}
VILLELA, J.M. Evaluation the expansion influence of the sugarcane on hydrosedimentological regime in the watershed stream Cana do Reino, Votuporanga SP. 2011. 132 p. Dissertation (Master) - Escola de Engenharia de São Carlos, Universidade de São Paulo, São Carlos, 2015.
\end{abstract}

The expansion of sugar cane cultivation motivated by the increased demand for ethanol after the launching of the fex fuel technology has resulted in major changes in the landscape. São Paulo state has absorbed many of the expansion areas settled in new regions. Such an expansion has given rise to reflections on the negative environmental impacts associated with sugarcane crop, especially regarding changes in the hydrosedimentological regime of river basins. The present study evaluates the influence of the expansion of sugar cane cultivation on hydrosedimentological aspects (rate of runoff and sediment production) in a region of significant increase in this culture. The study site is Cana do Reino watershed, located in Votuporanga city - SP. The evaluation was conducted through a comparison between the runoff rates and sediment yield for the scenarios before (2005) and after their expansion (2014) and based on SWAT model. Simulations of monthly average flow rates showed satisfactory results after calibration. Values of $0.85,0.82$ and -1.5 were obtained for the NashSutcliffe efficiency coefficient (NSE), coefficient of determination $\left(\mathrm{R}^{2}\right)$ and percentage of trends (PBIAS), respectively. The validation showed values of NSE, $\mathrm{R}^{2}$ and PBIAS of 0.76 , 0.81 and -9.0 , respectively. The simulations revealed the average rates of runoff and sediment yield for the 2005 scenario were $44 \mathrm{~mm}$ and 2.6 ton.ha $\mathrm{h}^{-1} \cdot \mathrm{ano}^{-1}$, whereas values of $70 \mathrm{~mm}$ and 4.5 ton.ha ${ }^{-1}$.ano ${ }^{-1}$ were obtained for the 2014 scenario. According to the results, SWAT model proved satisfactory for a comparative analysis between the scenarios.

Key words: Hidrosedimentology, sugarcane - expansion and SWAT Model. 


\section{LISTA DE FIGURAS}

Figura 1. Quadrilátero do Açúcar e formação de vilas na Província de São Paulo em 1846. Fonte: MULLER, 1923 apud PETRONE, 1968. 12

Figura 2. Áreas prioritárias pelo Programa de Expansão da Canavicultura para produção de combustível do Estado de São Paulo (Procana) em 1980. Fonte: (SAMPAIO, 2011)........................... 14

Figura 3. Expansão de cana-de-açúcar no estado de São Paulo.

Figura 4. Percentual de área cultivada com cana-de-açúcar em relação a área dos municípios do Estado de São Paulo no ano de 2004.

Figura 5. Percentual de área cultivada com cana-de-açúcar em relação a área dos municípios do Estado de São Paulo no ano de 2014. 17

Figura 6. Localização da microbacia do Córrego cana do Reino (Votuporanga - SP). 42

Figura 7. A) Mapa do trajeto e dos pontos de amostragem da coleta de solos; B) Foto ilustrando o entorno do ponto de amostragem $n^{\circ} 4$; C) Sondagem utilizando trado no ponto $n^{\circ} 4$ e D) Amostras de solos coletadas em três profundidades para o ponto $\mathrm{n}^{\circ} 4$

Figura 8. Visita de campo da microbacia córrego Cana do Reino, Votuporanga - SP. 52

Figura 9. Localização da estação climatológica do IAC - Votuporanga e dos postos de monitoramento pluviométrico e fluviométrico do DAEE. 55

Figura 10. Interface do Módulo Watershed Delineator do ArcSWAT 2009.93.7b............................ 56

Figura 11. Interface do Módulo HRU Definition do ArcSWAT 2009.93.7b. ................................... 58

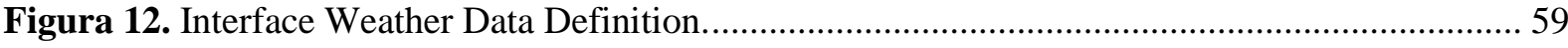

Figura 13 Mapa hipsométrico da microbacia do córrego Cana do Reino, Votuporanga - SP............. 66

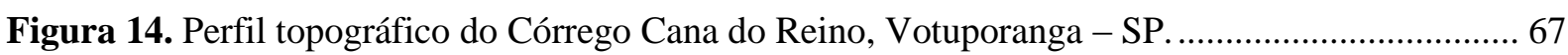

Figura 15. Classes de declividade da microbacia do córrego Cana do Reino, Votuporanga - SP....... 68

Figura 16. Mapeamento das classes de solos definidas pelo levantamento pedológico. ...................... 69

Figura 17. Tipos de usos de solo presentes na microbacia no cenário de 2005

Figura 18. Evolução do cultivo de cana-de-açúcar na microbacia no cenário de 2014 e no município de Votuporanga.

Figura 19. Expansão do cultivo de cana-de açúcar (2004- 2014) na microbacia................................. 73

Figura 20. Mapa de uso e ocupação para o cenário de 2014 ................................................................. 74

Figura 21. Divisão das sub-bacias na microbacia do córrego Cana do Reino, Votuporanga - SP. ..... 76

Figura 22. Hietograma e hidrogramas observado e simulado (sem calibração) mensal para o período de 2004 a 2010.

Figura 23. Diagrama de dispersão das vazões médias mensais observadas e simuladas (sem calibração) para o período de 2004 a 2010 na microbacia. 78

Figura 24. Resultado análise de sensibilidade dos parâmetros do SWAT para a microbacia 81 
Figura 25. Hietograma e hidrogramas observado e simulado (calibrado) mensal para o período de 2004 a 2010. 85

Figura 26. Hietograma e hidrogramas observado, simulado (calibrado) e (sem calibração) mensal para o período de 2004 a 2010.

Figura 27. Diagrama de dispersão das vazões médias mensais observadas e simuladas (calibrado) para o período de 2004 a 2010 na microbacia.

Figura 28. Hietograma e hidrogramas observado e simulado mensal para o período de verificação de 2011 a 2014.

Figura 29. Diagrama de dispersão das vazões médias mensais observadas e simuladas para o período de verificação de 2004 a 2010 na microbacia. 88

Figura 30. Hietograma e hidrogramas observado e simulado mensal para o período de calibração e verificação de 2004 a 2014. 89

Figura 31. Diagrama de dispersão das vazões médias mensais observadas e simuladas para o período de de 2004 a 2010 na microbacia. .90

Figura 32. Mapa da produção de escorrimento superficial para o cenário de 2005 92

Figura 33. Mapa da produção do escorrimento superficial para o cenário de 2014. 94

Figura 34. Mapa da produção de sedimentos para o cenário de 2005. .96

Figura 35. Mapa da produção de sedimentos para o cenário de 2014. 99

Figura 36. a) comparação entre as produções de escorrimento superficial dos cenários de 2005 e 2014 para a sub-bacia 24.b) comparação entre as produções de sedimentos dos cenários de 2005 e 2014 para a sub-bacia 24.

Figura 37. a) comparação entre as produções de escorrimento superficial dos cenários de 2005 e 2014 para a sub-bacia 26. b) comparação entre as produções de sedimentos dos cenários de 2005 e 2014 para a sub-bacia 26. 106 


\section{LISTA DE TABELAS}

Tabela 1. Parâmetros de solos exigidos pelo Modelo SWAT. 49

Tabela 2. Enquadramento das classes de uso e ocupação da microbacia com as classes do banco de dados do SWAT. 53

Tabela 3. Percentual e a área de cada classe de uso presente na microbacia no cenário de 2005 ........ 72

Tabela 4. Mudanças de uso e ocupação entre os cenários de 2005 e 2014. 75

Tabela 5. Resultado das análises de sensibilidade global e individual 79

Tabela 6. Valores de $t$-stat e $P$-Value obtidos pela análise de sensibilidade dos parâmetros. 82

Tabela 7. Parâmetros, métodos, intervalos e valores resultantes da calibração para a microbacia. ..... 83

Tabela 8. Classificação do desempenho para as estatísticas NSE e PBIAS em nível mensal. 86

Tabela 9. Avaliação da precisão das simulações não calibrada, calibrada e verificação e calibrada (2004 a 2014. 90

Tabela 10. Produção de sedimentos entre as sub-bacias dos cenários de 2005 e 2014 101

Tabela 11. Mudança de uso e ocupação ocorrida na sub-bacia 25 entre os cenários de 2005 e 2014.103

Tabela 12. Mudança de uso e ocupação ocorrida na sub-bacia 26 entre os cenários de 2005 e 2014.105

Tabela 13. Estimativa da produção média de sedimentos para dois tipos de usos. 107 


\section{LISTA DE SIGLAS}

IAA - Instituto de álcool e açúcar

SWAT - Soil and Water Assessment Tools

HRU - Hydrologic Response Unit

CLUE-S - Conservation of land use and its Effects at Small Region Extent

UGRHI - Unidade de Gerenciamento de Recursos Hídricos

MDE - Modelo Digital de Elevação

IPT - Instituto de Pesquisa Tecnológica

IAC - Instituto Agronômico de Campinas

USGS - United States Geological Survey

GLUE - Generalized Likelihood Uncertainty Estimation

ParaSol - Parameter Solution

SUFI2 - Sequential Uncetainty Fitting

MCMC - Markov Chain Monte Carlo

NSE - Coeficiente de Eficiência Nash e Sutcliffe

PBIAS - Percent bias measures the average tendency of the simulated 


\section{INTRODUÇÃO}

A falta de planejamento e gestão territorial combinado ao crescimento populacional tem contribuído para a utilização e a exploração inadequada dos recursos naturais. O mau uso e manejo do solo tem sido um fator determinante para sua degradação, além de acarretar grandes impactos nos recursos hídricos.

Alguns processos como a erosão, lixiviação e alterações na cobertura vegetal ocorrem de forma natural, porém quando o homem modifica o ambiente, esses processos são potencializados, ocasionando um desequilíbrio ambiental. Essas modificações são provocadas pela necessidade de expansão das zonas urbanas e a crescente demanda por áreas agricultáveis para a produção de alimentos, fibras e biocombustíveis.

A expansão do cultivo de cana-de-açúcar, motivada pelo lançamento da tecnologia flex fuel na última década, resultou em grandes mudanças na paisagem. Estas mudanças foram percebidas mais facilmente no Estado de São Paulo, sendo que em 2004 o cultivo estava presente em 389 municípios, e no ano de 2014 em 484 (RUDORFF et al. 2010; INPE, 2014). Segundo dados do Projeto CanaSat para o estado, a quantidade de área plantada passou de 3,0 milhões de hectares em 2004 para 5,7 milhões no ano de 2014, representando um aumento de aproximadamente 92\% (INPE, 2014). Esses dados demonstram o significativo avanço desta cultura nos municípios paulistas, que expandiu seus cultivos para outras cidades e aumentou a quantidade de área plantada onde já estava presente.

O aumento dessas áreas gera não apenas questões de competição entre outras culturas, como também impactos na paisagem, com a redução da vegetação nativa, alterações no microclima e degradação do solo, dos recursos hídricos e alterações no regime hidrossedimentológico. 
Para realizar o gerenciamento dos recursos hídricos visando o seu planejamento, faz-se necessário à avaliação quantitativa e qualitativa de alguns processos atuantes na bacia, como a produção de água e de sedimentos. Do ponto de vista econômico e operacional, é inviável monitorar processos que ocorrem em toda a bacia, como por exemplo, a erosão hídrica. Desta forma, os modelos matemáticos que preveem o aporte de sedimentos em bacias hidrográficas surgem como uma ferramenta interessante para auxiliar na gestão de bacias, complementando as informações da rede de monitoramento.

Dentre os modelos que vem sendo utilizados para o planejamento de bacias rurais, o SWAT (Soil and Water Assessment Tool) destaca-se no cenário. O modelo permite estimar e fornecer de forma espacializada as taxas de escorrimento superficial, subterrâneo, produção de sedimentos e qualidade da água em bacias rurais. Tais características deixam evidente o potencial de aplicação do modelo em estudos hidrossedimentológicos, sobretudo em bacias hidrográficas que passaram por grandes modificações em seu uso e cobertura do solo.

Nesse contexto, foi escolhido como estudo de caso a microbacia do córrego Cana do Reino que está localizada no município de Votuporanga - SP, onde constatou-se uma altíssima taxa de crescimento e substituição de outras culturas por cana-de-açúcar. A microbacia com área de 4.216 hectares, passou de uma ocupação de 324 ha do cultivo em 2005, para 1.762 ha no ano de 2014, área equivalente a $41 \%$ da microbacia.

Desta forma, mostra-se relevante e indispensável, estudos sobre os efeitos da expansão do cultivo de cana-de-açúcar no regime hidrossedimentológico da microbacia, relacionados os mesmos com as taxas de escorrimento superficial e produção de sedimentos. 


\section{OBJETIVOS}

O objetivo geral do estudo é analisar a influência da expansão do cultivo de cana-deaçúcar no regime hidrossedimentológico na microbacia do córrego Cana do Reino, Votuporanga - SP.

Para alcançar o objetivo principal do estudo, propõe-se a realização dos seguintes objetivos específicos:

$\checkmark$ Elaborar o Banco de Dados Cartográficos e Tabulares para efetuar as simulações;

$\checkmark$ Calibrar o modelo SWAT para a microbacia do córrego Cana do Reino;

$\checkmark$ Comparar as taxas de escorrimento superficial e produção de sedimentos entre os períodos de início (2005) e expansão (2014) do cultivo da cana-de-açúcar na microbacia;

$\checkmark$ Mapear as áreas com maior potencial de produção de sedimento. 


\section{REVISÃO BIBLIOGRÁFICA}

Este capítulo compreende o referencial teórico utilizado para embasar o conhecimento acerca dos processos empregados para a realização dos objetivos propostos.

\subsection{Histórico}

O período de colonização do Brasil se deu, principalmente, no litoral nordestino. A cultura da cana de açúcar nessa região foi favorecida por fatores climáticos, características do solo, além da proximidade a Portugal, que aproveitou seu potencial exportador, tornando essa atividade o núcleo econômico do Brasil colônia (FAUSTO, 2006).

A cana-de-açúcar se expande pelo Nordeste, a partir da Zona da Mata em 1534, fato que direcionou esforços da Capitania de Pernambuco, sob o comando de Duarte Coelho, a construir os engenhos (FIGUEIREDO, 2008). Fausto (2006) destaca Bahia, Pernambuco e Rio de Janeiro como sendo os principais centros produtores da época e considera o período de 1570-1670 um momento de alta produção e lucratividade do mercado açucareiro, denominado pelo autor como "século do açúcar".

O ciclo do açúcar estava alicerçado no chamado "Plantation" que se sustenta por três elementos básicos: latifúndio, monocultura e trabalho escravo. Deste molde de desenvolvimento, nasce no Brasil a grande propriedade rural e a sociedade patriarcal e escravocrata.

Com a contínua expansão das áreas do cultivo e o aumento do número de engenhos, a exportação do país progrediu, alcançando a marca de 19 mil toneladas anuais em 1700 e 24 mil toneladas no ano de 1800 (CORTEZ, 2010). Segundo Prado Jr. (1976), o Brasil era o maior produtor mundial de açúcar até o século XVII. No entanto, a partir 1670 o valor de exportação sofre sucessivas quedas, e em 1760, no auge do ciclo do ouro, inicia-se a fase de expressiva decadência da cana-de-açúcar (FAUSTO, 2006). 
Figueiredo (2008) aponta alguns motivos que contribuíram para o declínio da atividade açucareira, como: fatores políticos externos e internos, circunstâncias de guerras, descoberta de ouro e outras atividades mais lucrativas que deixavam a agricultura com pouca mão de obra, abertura dos portos que alavancou o comércio, concorrência com o açúcar estrangeiro e o crescimento da cultura do café no século XIX.

A alta do café na região Centro-Sul e o enfraquecido setor açucareiro no Nordeste fizeram com que os senhores de engenho vendessem seus escravos com a promessa de trabalho "assalariado" nas fazendas do Rio de Janeiro e São Paulo (SANTOS, 2010). Diante disso, o século XX foi marcado pelo crescimento da atividade canavieira no Centro-Sul, principalmente, o Estado de São Paulo que passa a ser o maior produtor do Brasil, título que se mantém até atualidade.

O fim do ciclo do café, entre as décadas de 1920 e 1930, culminou em grandes alterações no interior do estado de São Paulo. O arranjo agroindustrial canavieiro passa por alterações no padrão do açúcar que era consumido e produzido, bem como alterações no padrão dos produtores e localidade da região produtora de origem, dando início à época da burguesia industrial do açúcar, que substitui os barões das fases anteriores (QUEDA, 1972 apud SAMPAIO, 2010).

Em 1923, o Instituto Nacional de Tecnologia dá início a um programa sobre experimentação do álcool puro em motores do ciclo Otto. Neste período, intensificam-se as pesquisas na tecnologia para fabricação do motor a álcool e do próprio álcool mais concentrado, já que se tinha um bom conhecimento adquirido na fabricação da cachaça (CORREIA, 2005).

Até o momento, o álcool era um subproduto da produção de açúcar e sua estrutura de produção contava com poucas usinas. Realidade que mudou após a modernização estimulada pelo novo governo. A intensificação dos investimentos tinha como objetivo amenizar as 
sucessivas crises do mercado açucareiro, possibilitando a transformação dos excedentes de açúcar em combustível, na tentativa de reduzir a quantidade de petróleo que era importado (MOREIRA; SZMRECSÁNYI, 1991).

A pressão por medidas protecionista ao setor cresce sobre o governo, que em meio à crise de 1929, começa a se mobilizar no sentido de políticas de proteção a agroindústria canavieira e em 1933 cria o Instituto do Açúcar e do Álcool (IAA). A criação do IAA deu esperança aos produtores, sobretudo das regiões Norte-Nordeste e do Rio de Janeiro, com o fornecimento de subsídios e a implantação de mecanismos como a centralização das operações de exportação brasileira. Assim, o IAA passa a ser a única instituição autorizada a comprar açúcar do mercado doméstico e estabelecer contratos de exportação (VIEIRA; LIMA; BRAGRA, 2007).

Outro incentivo do governo Getulio Vargas dado ao setor, foi o Decreto 19.717 de 20 de Janeiro de 1931, o qual determinava a obrigatoriedade da inserção de 5\% de álcool em toda a gasolina que era importada (NATALE NETTO, 2007). Por meio da Resolução de 1941, elevou-se de $5 \%$ para $20 \%$ o teor obrigatório de álcool na gasolina utilizada no país (SZMRECSÁNYI; 1979).

No período de 1942 até 1956, houve um aumento destas porcentagens na mistura, chegando a um valor máximo de $42 \%$ na região Nordeste. Com os preços do mercado externo de açúcar emparelhado com o álcool no mercado interno, favoreceu o aumento das porcentagens de álcool na gasolina, que se deu de forma desordenada atendendo apenas as necessidades do setor agro-açúcareiro (CARVALHO, 1993). O aumento desordenado do teor de álcool no combustível gerou um descontentamento do mercado consumidor e da indústria automobilística, devido ao rendimento variável dos motores.

A elevação dos preços do açúcar no mercado externo, juntamente com a baixa dos preços do petróleo nos mercados internacionais, levou a redução do volume de álcool 
misturado no combustível, entre 1960 e 1965. Com a baixa no mercado internacional do açúcar nos anos de 1966 e 1967, os teores de álcool na gasolina alcançam níveis máximos de 13,5\% no Estado de São Paulo e 6,2\% na média nacional (CORREIA, 2007).

A década de 70 foi considerada um marco na história do álcool no Brasil. Com o choque dos preços do petróleo em outubro de 1973, os países importadores sentiram o forte impacto em suas economias, dentre eles o Brasil. O país vivia o denominado Milagre Econômico Brasileiro, com altas taxas de crescimento desde o final dos anos 60, ritmo que se manteve mesmo sob o novo contexto (MOREIRA; SZMRECSÁNYI, 1991). Segundo Correia (2007), em 1973 o Brasil importava o equivalente a 80\% de sua demanda de petróleo. Diante de tal dependência, era evidente a necessidade de novas alternativas para substituição ainda que parcial, da fonte de energia oriunda de combustíveis fósseis.

Neste contexto, em outubro de 1975 nasce o Programa Pró-Álcool, sob o Decreto 76.593, com o objetivo de incentivar o uso do etanol visando à redução das importações combustíveis fósseis, que na época representava $50 \%$ da balança comercial. (MOREIRA; GOLDEMBERG, 1999). O programa também tinha a proposta de favorecer o setor açucareiro, que estava em baixa no mercado internacional. A partir deste momento, o álcool carburante deixa de ser uma alternativa para os excedentes da indústria açucareira e passa a figurar um papel importante na redução das importações (MOREIRA; GOLDEMBERG, 1999).

Desta forma, o governo ajudava as indústrias ligadas ao setor, concedendo financiamentos subvencionados para implantação de novas destilarias, justificando as ações com os argumentos sociais e econômicos com menção à balança comercial. Nos primeiros anos de sua implantação, o programa conseguiu substituir apenas $14 \%$ da gasolina utilizada. Os resultados alcançados evidenciam que de início, o programa veio mais para livrar o setor açucareiro da crise do que como uma política de substituição energética (CORREIA, 1996). 
O ano de 1979 é marcado pelo segundo choque do petróleo e um movimento de alta nas taxas de juros internacionais. Estes dois eventos ocasionaram grande impacto na economia brasileira, já que as taxas de importações eram de $86 \%$ além disso, o país encontrava-se em grande fase de endividamento externo. Com o objetivo de reequilibrar a dívida externa, o Brasil lança o Modelo Energético Brasileiro (MEB) que traçava metas para o setor energético com projeções até 1985 (MOREIRA; GOLDEMBERG, 1999; CORREIA, 2007).

Dentre as metas estabelecidas pelo MEB estava a criação de programas para substituir os derivados do petróleo, causa na qual o Pró-Álcool já militava e que após receber mais incentivos, ajudaria o país no cumprimento das metas. O MEB estabeleceu a meta de aumentar sua capacidade produtiva de álcool para o ano 1985 , em 10,7 milhões de $\mathrm{m}^{3}$ (CORREIA, 2007). Neste período, foram intensificados os créditos e subvenções para implantação de novas destilarias a fim de atender as demandas por álcool hidratado para abastecer os novos modelos de automóveis movidos exclusivamente por este combustível.

Os primeiros automóveis movido a álcool hidratado começam a circular em 1979 e no ano seguinte as vendas são estendidas ao grande público. A entrada destes veículos no mercado foi facilitada pelos subsídios ao preço do álcool e pelo custo inferior destes modelos se comparados com os movidos à gasolina. Para aumentar ainda mais a aceitação do mercado por estes automóveis, em 1980, o governo concede um aumento de $42 \%$ no preço da gasolina, deixando o álcool mais competitivo, o qual era vendido a 59\% do preço da gasolina. (CORREIA, 1996).

Somente após o segundo choque do petróleo e das condições econômicas desfavoráveis, que o Pró-Álcool ganha força. Esta evolução pode ser vista nos valores de consumo em 1981, que era de 2,5 milhões de $\mathrm{m}^{3}$, passando para 12,7 milhões em 1989, um aumento considerável de 60,5\% (CORREIA, 1996). Nesta nova fase do Pró-Álcool, o foco do 
governo passa a ser a inclusão representativa desta fonte de energia na matriz energética brasileira, ao contrário da fase inicial do programa que tinha como objetivo principal, proteger o setor açucareiro.

A volta da estabilidade dos preços do petróleo promoveu a redução dos preços da gasolina e do álcool no mercado interno. Tal redução refletiu negativamente sobre o setor de álcool e açúcar, levando a uma estabilização de sua produção. Ao passo que a produção de álcool se estabilizava, a demanda por álcool hidratado aumentava exponencialmente, devido a considerável participação destes veículos no mercado. Com estes agravantes se configurou uma situação de eminente crise de oferta em um futuro próximo (VIEIRA; LIMA; BRAGRA, 2007).

Para piorar ainda mais a situação, em 1989 o preço do açúcar é elevado no mercado internacional, fazendo com que o setor reduzisse a produção de álcool e intensificasse a produção de açúcar para atender as demandas internacionais.

A elevação dos preços do açúcar no mercado internacional foi o elemento que fez eclodir a crise do Pró-Álcool. Não demorou muito para a ausência do produto no mercado começar a imobilizar a frota de veículos e o governo dar início a corrida de importações de álcool e metanol, tentando estabilizar o mercado. As medidas adotadas pelo governo de importar alcoóis e metanol não surtiram o efeito desejado, por ser de composição diferente do álcool extraído da cana-de-açúcar, trouxe complicações ao funcionamento dos veículos. Além disso, alguns poderes locais proibiram o consumo devido aos danos ambientais (CORREIA, 2007).

Em decorrência disso, toda imagem criada pelo Pró-Álcool, promovendo o álcool como sendo uma fonte de energia viável e promissora para o mercado nacional é destruída. Este fato começa a refletir na comercialização dos veículos movidos a álcool, que perde seu prestigio e gradativamente deu lugar ao retorno dos veículos movidos à gasolina. 
A década de 1990 foi marcada pela desregulamentação econômica a partir do fim do regime militar. A desregulamentação aliada ao novo contexto de intensa globalização fez com que governo Collor pusesse fim ao IAA, acabando com os subsídios cedidos à produção de açúcar (BARROS; MORAES, 2002).

Quase uma década depois da crise de oferta de álcool combustível em 1989, o mercado do petróleo passa por um novo aumento, deixando o álcool mais viável economicamente (CORREIA, 2005). Porém, com a insegurança gerada pela crise, o mercado automobilístico para veículos movidos a álcool se mantém estável. O aumento nos preços do petróleo e o advento dos veículos "flex-fuel" (movidos a álcool e gasolina) alavancou o setor novamente.

Os Estados Unidos foram pioneiros nos estudos da tecnologia "flex-fuel" em 1980, lançando seus primeiros veículos em 1988. Segundo Correia (2007), tecnologia utiliza uma sonda lambda em um motor ciclo Otto para medir a mistura de gases que saem do motor e um controlador que regula a entrada do combustível e o tempo da faísca para corrigir a qualidade da mistura.

A estreia dos veículos "flex-fuel" no Brasil ocorreu em maio de 2003, com o lançamento pela Volkswagen do modelo Gol 1.6 Total flex. O sucesso dos modelos Total flex, fez com que outras montadoras oferecessem modelos com a nova tecnologia (CORREIA, 2005).

A possibilidade de escolha entre abastecer o veículo com álcool ou gasolina, permitindo driblar as oscilações de preços de cada combustível, mais o discurso ambientalista antipoluição, contribuíram para o sucesso de vendas dos veículos "flex-fuel”. Segundo dados da Anfavea (2013), a venda destes veículos representou 94\% do total de veículos vendidos.

Diante da preocupação com as alterações climáticas, o uso do etanol consegue reduzir as emissões de gases do efeito estufa, o que contribui com a melhoria da qualidade do ar, 
principalmente, em grandes centros urbanos (GOLDEMBERG; COELHO; GUARDABASSI, 2008).

Neste contexto, a crescente demanda de etanol e açúcar, conduziu o setor sucroalcooleiro a fazer altos investimentos para ampliação de suas unidades de processamento e a expandir o cultivo da cana-de-açúcar (FREITAS; KANEKO, 2011). A tendência de crescimento da produção de etanol pode ser explicada pela alta nos preços da gasolina junto ao apelo ambiental pela redução das emissões de $\mathrm{CO}_{2}$. Já o aumento na produção de açúcar, pode ser atribuído ao maior volume exportado (GOLDEMBERG; COELHO; GUARDABASSI, 2008). Os investimentos em torno do etanol, fez com que o Brasil se tornasse o líder mundial na produção de cana-de-açúcar. De acordo com Fao (2012), a produção nacional de cana-de-açúcar superou em $48 \%$ a Índia, segunda colocada mundial.

É evidente que o impulso dado ao setor, após o lançamento dos veículos "flex-fuel", resultou em grandes transformações espaciais. Desta forma, o próximo item deste capítulo tem como objetivo mostrar a distribuição espacial da expansão da cana-de-açúcar ao longo da história, no estado de São Paulo.

\subsection{Expansão da cana-de-açúcar no Estado de São Paulo}

O cultivo da cana de açúcar está presente em quase todos os estados brasileiros em diferentes níveis de ocupação. A região Centro-Sul é a maior produtora, com $91 \%$ da produção nacional, seguida pela região Norte-Nordeste com 9\%. O estado de São Paulo é o polo nacional produtor de açúcar e álcool, representando 56\% da produção de cana-de-açúcar e 51\% de álcool. Na safra de 2012 e 2013 foram produzidos respectivamente, 329.923 mil toneladas de cana-de-açúcar e $11.830 \mathrm{~m}^{3}$ de etanol (UNICA, 2014). Para entender como o estado de São Paulo se estruturou para alcançar tal marca, e também reforçar as justificativas 
pela escolha da área de estudo, será apresentado a seguir, como a cana-de-açúcar se distribuiu espacialmente, formando as tradicionais regiões canavieiras e as novas tendências.

No século XVIII, os engenhos de açúcar e cachaça se concentravam na região litorânea de São Paulo. Na transição para o século XIX, surgiram duas novas áreas canavieiras, uma no Vale do Paraíba e outra conhecida como o "Quadrilátero do Açúcar" (Figura.1), formada pelos municípios de Sorocaba, Jundiaí e Campinas. (PETRONE, 1968).

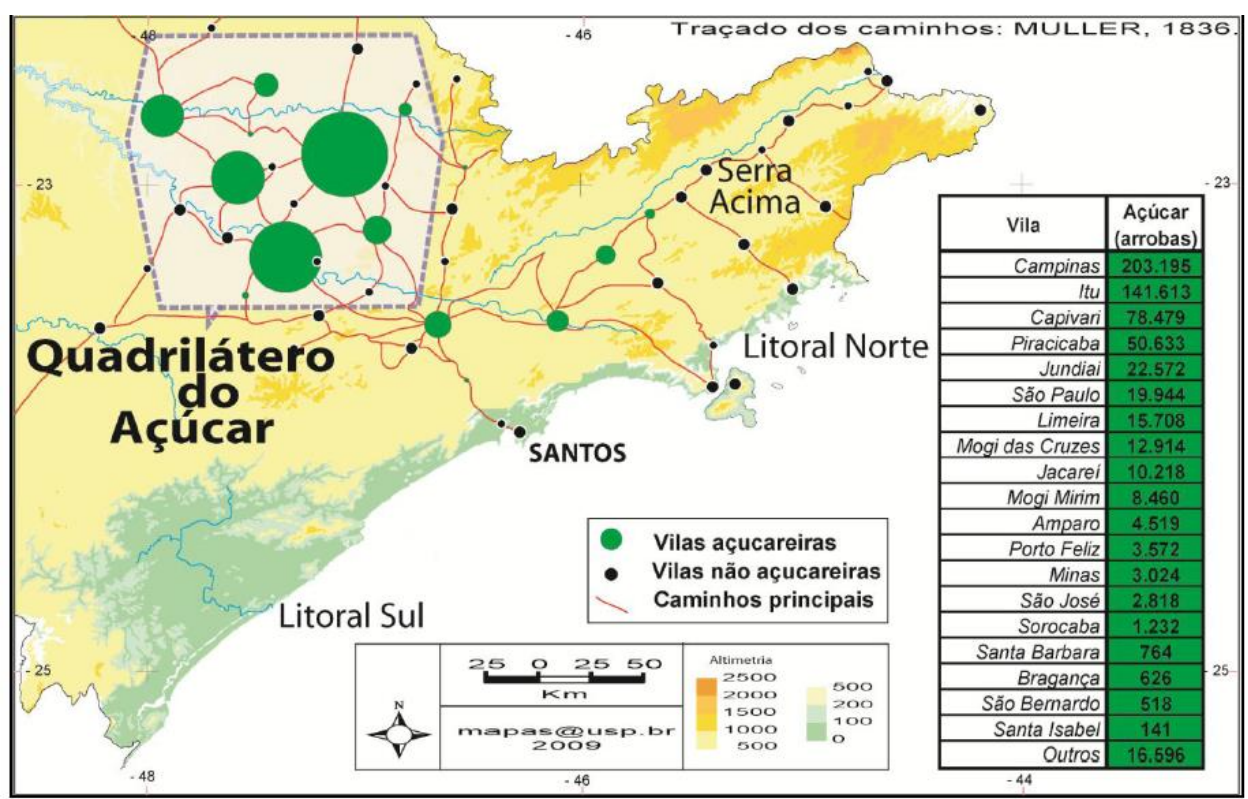

\section{Figura 1. Quadrilátero do Açúcar e formação de vilas na Província de São Paulo em 1846. Fonte: MULLER, 1923 apud PETRONE, 1968}

A formação do complexo açucareiro resultou no primeiro surto econômico do Estado, que se expandiu anos depois para a região de Araraquara - SP. Essa nova região açucareira, (contendo dezesseis fazendas), tinha participação incipiente quando comparada as regiões tradicionais (61 fazendas em Piracicaba e 27 em Mogi-Mirim) (CASALECCHI, 1973). O predomínio da atividade canavieira e pecuária extensiva se manteve até 1860 , quando os canaviais começam a demandar mais área, se deslocando para a região Oeste de São Paulo. Posteriormente, a infraestrutura econômica formada pelas novas áreas de cana-deaçúcar facilitou à introdução da cultura cafeeira (PETRONE, 1968). 
A agroindústria do açúcar ganha novo ritmo após a segunda guerra mundial e a liberalização do Estado Nacional. O Decreto-Lei 9827 (BRASIL, 1946) incentivou o consumo interno e favoreceu, principalmente, os produtores paulistas que passaram a aumentar suas quotas e a expandir seus canaviais para os estados vizinhos, como o Paraná (BRAY, 1980).

O aumento do consumo no mercado interno fez com que o setor buscasse maior eficiência nos processos produtivos, dando início à fase de modernização. Neste aspecto, o estado de São Paulo se destacou em relação ao Nordeste, tendo melhores condições para atender à crescente demanda do Centro-Sul (FERREIRA; ALVES, 2009). O mesmo autor destaca a importância da participação do Grupo Dedini de Piracicaba - SP em dois momentos na expansão: aumento da capacidade das moendas e no início da fabricação de destilarias de álcool.

Durante o Governo Dutra houve uma significativa expansão das usinas de álcool e açúcar no estado de São Paulo. No início de seu mandato em 1946, o estado contava com 40 usinas, número que praticamente dobrou ao fim da era Dutra (1951), com 79 usinas. O motivo de tal avanço foi atribuído ao estimulo dado pelo Decreto-Lei $\mathrm{N}^{\circ}$ 9827, que promoveu expansão do setor, resultando na consolidação da região canavieira de Araraquara e no surgimento das novas regiões produtoras como Jaú e Paranapanema (BRAY, 1980).

Andrade (1981) destaca que os vários incentivos dados ao setor resultaram na concentração de renda, devido à aquisição de terras mais baratas e distantes dos centros tradicionais. O mesmo autor complementa que o avanço da cana se deu sobre áreas que anteriormente eram ocupadas por culturas alimentícias.

Já em 1975, com a implantação do Proálcool, o governo estabeleceu metas para ampliar a produção e a capacidade de processamento, por meio de projetos anexos a usinas já existentes ou mesmo autônomos. Esta primeira fase do programa não resultou no acréscimo de grandes áreas, já que projetos foram direcionados para regiões tradicionais como: 
Piracicaba, Sertãozinho, Ribeirão Preto, Araraquara, Jaú e Vale do Paranapanema (BRAY; FERREIRA, 1983).

Após o segundo choque do petróleo, em 1979, o governo decidiu mudar o foco dos investimentos, passando a direcionar o crescimento para a região Oeste do estado de São Paulo. As diretrizes para o planejamento foram estabelecidas pelo Plano de Desenvolvimento do Oeste do Estado de São Paulo (Pro-Oeste) em 1980, que por meio do Programa de Expansão da Canavicultura para produção de Combustível do Estado de São Paulo (Procana), deu novos rumos à cultura canavieira (SAMPAIO, 2010). Desta forma, o Procana definiu a prioridade de investimentos para as regiões administrativas de Presidente Prudente, Araçatuba, Bauru e a porção Oeste da Região de São José do Rio Preto (Figura 2). As regiões de Marília e o Centro-Leste de São José do Rio Preto foram consideradas como de menor prioridade (BRAY; FERREIRA, 1983).

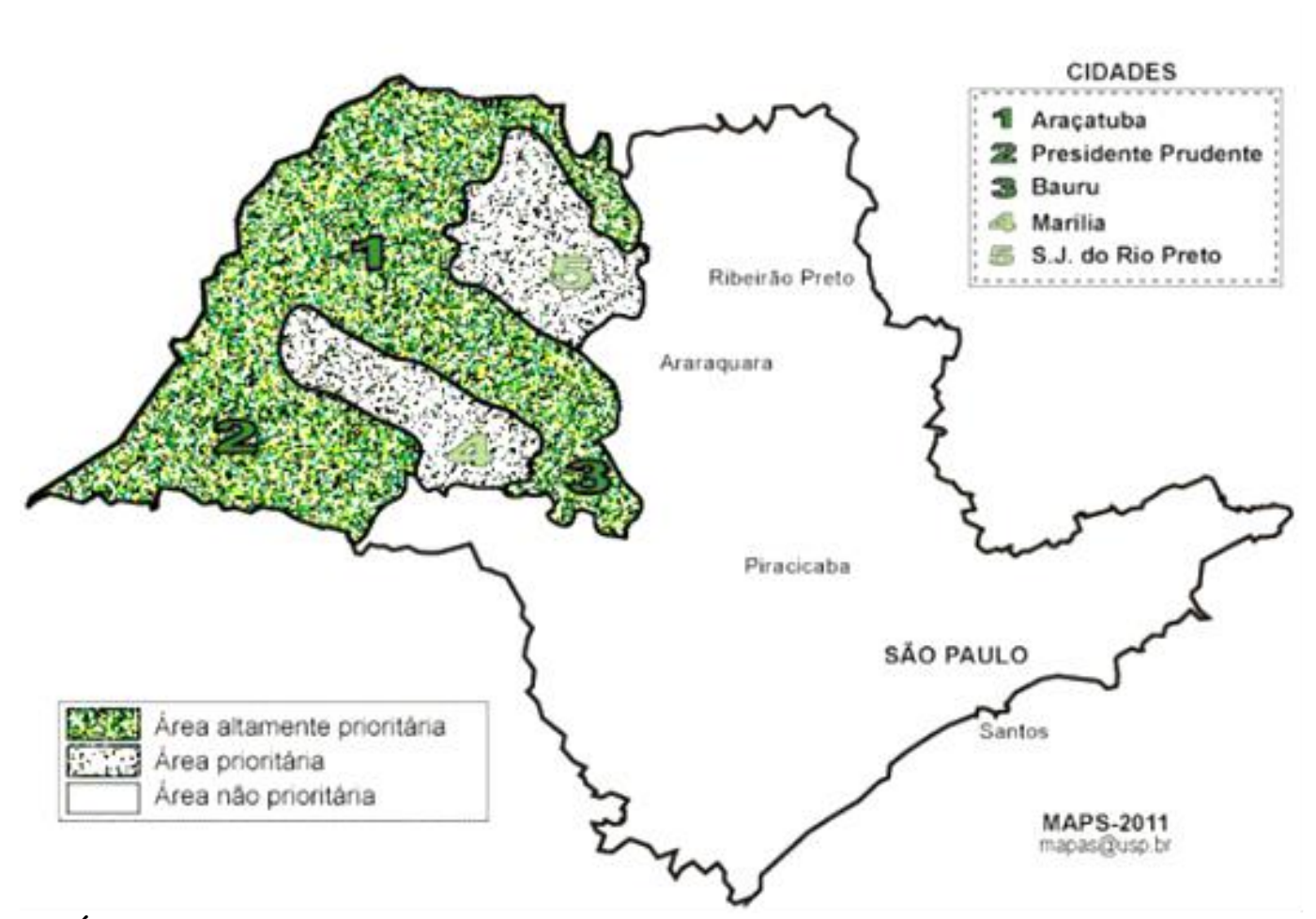

Figura 2. Áreas prioritárias pelo Programa de Expansão da Canavicultura para produção de combustível do Estado de São Paulo (Procana) em 1980. Fonte: (SAMPAIO, 2010)

O Procana tinha como objetivo direcionar investimentos para a região Oeste, utilizando como estratégia o consórcio cana-boi, de modo a permitir o equilíbrio econômico 
das regiões administrativas do estado de São Paulo (REGO, 1990; BINI, 2009). As políticas estatais de expansão e modernização aplicadas ao setor trouxeram bons resultados em termos de produtividade, tendo em vista os resultados da safra de 1987/1988 da região Oeste, que já representava 25\% da produção estadual (FERREIRA; ALVES, 2009).

Na década de 90, a região Centro-Sul superou as exportações de açúcar do Norte Nordeste na safra de 1993/1994. Embora os resultados favoráveis, o setor vivia a crise da desregulamentação originada pelo fim do IAA (Instituto de Açúcar e Álcool) em 1990, gerando muitas fusões e aquisições por grupos nacionais e em menor número internacionais (VIEIRA; LIMA; BRAGA, 2007).

A entrada do novo milênio trouxe fôlego à agroindústria canavieira e estabeleceu um marco histórico para o setor, que no período do Governo Lula (2003-2010), conseguiu dobrar sua produção. Este resultado anunciou o Oeste paulista como sendo mais uma das regiões canavieiras do Brasil. Segundo Sampaio (2010) surge um novo conceito de "Macrorregião Canavieira Paulista”. Este conceito está baseado na ausência de manchas de descontinuidade do cultivo, entre a união das tradicionais regiões canavieiras (Quadrilátero do Açúcar, Piracicaba, Ribeirão Preto/Sertãozinho, Araraquara, Jaú, Vale do Paranapanema, Araras e Catanduva) com as novas regiões formadas pelas zonas de São José do Rio Preto, Araçatuba e Presidente Prudente, situadas no Oeste do estado (SAMPAIO, 2010).

A incorporação das novas regiões canavieiras permitiu um salto na produção de cana-de-açúcar. Este aumento é confirmado pelos valores de área plantada, que em 1980 ocupava aproximadamente 1,0 milhão de hectares, passando a ocupar em 2014, uma área de cerca de 5,7 milhões de hectares (UNICA, 2014).

A rápida expansão dos canaviais modificou a configuração espacial dos municípios paulistas, que em 2004 estava presente em 60\% dos municípios. No ano de 2008 este valor aumentou para 71\%, e em 2014 o cultivo alcançou 75\% dos municípios. Nota-se na Figura 3 
que deste grupo, 112 municípios possuem de $40 \%$ a $60 \%$ do seu território ocupado com cana-de-açúcar, valor que para o mesmo nível de ocupação em 2004 era de 38, evidenciando o grande avanço na cultura neste período. Observa-se que o nível de ocupação superior ou igual a 70\% passou de 16 municípios em 2004, para 26 em 2014.

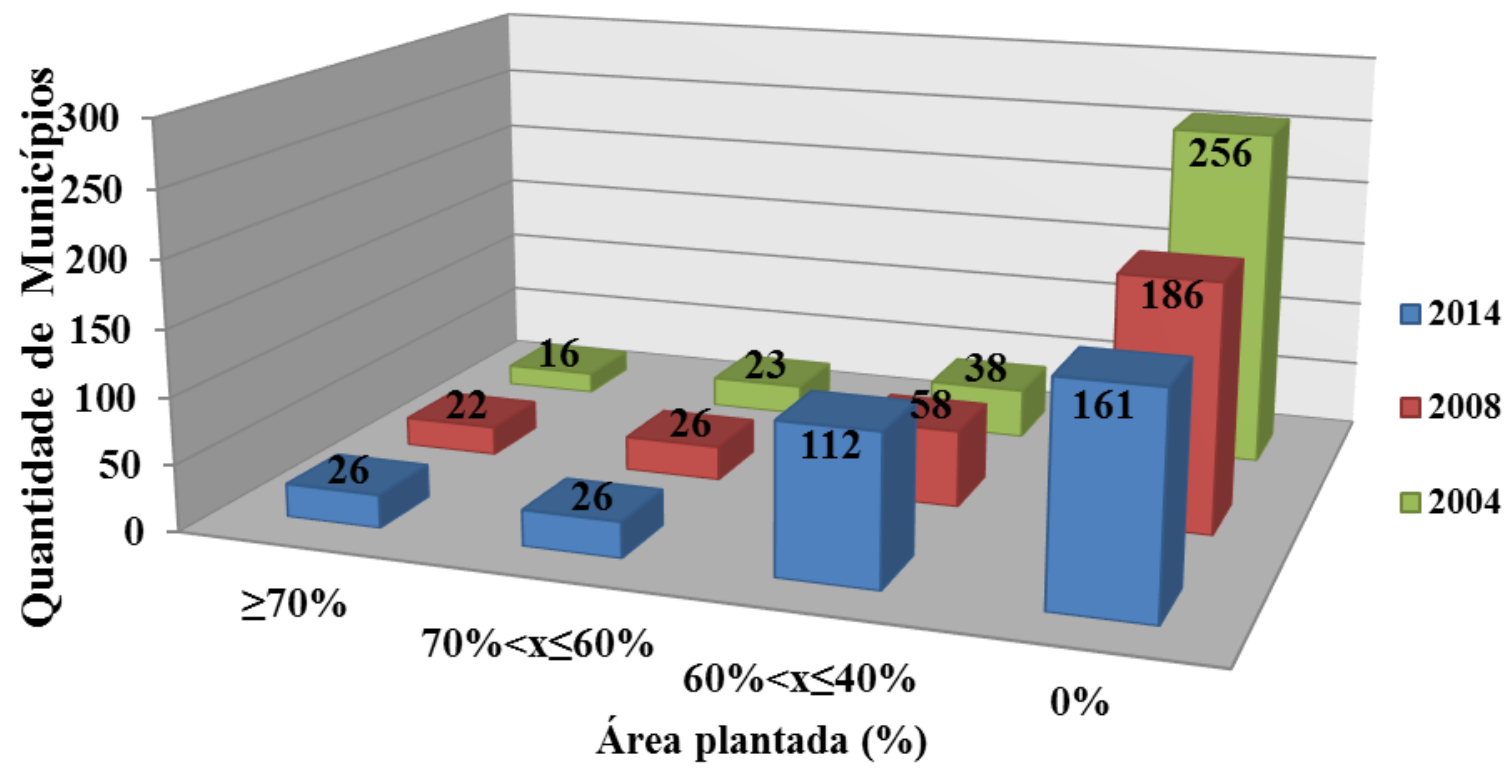

Figura 3. Expansão de cana-de-açúcar no estado de São Paulo.

Fonte: Adaptado de Projeto CanaSat (INPE, 2014).

As Figuras 4 e 5 apresentam respectivamente o percentual de área cultivada com canade-açúcar em relação a área dos municípios do Estado de São Paulo, para os anos de 2004 e 2014. 


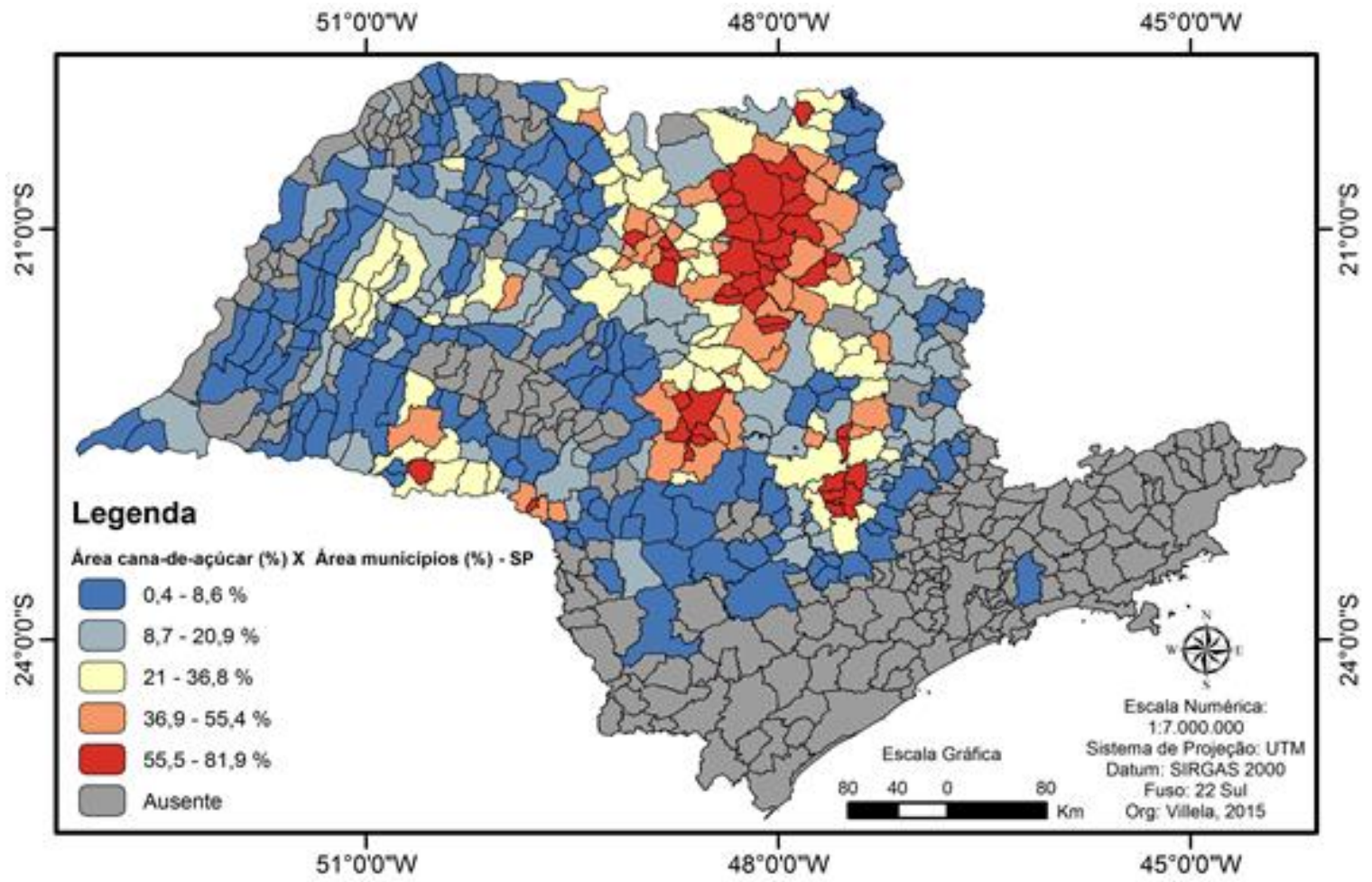

Figura 4. Percentual de área cultivada com cana-de-açúcar em relação a área dos municípios do Estado de São Paulo no ano de 2004.

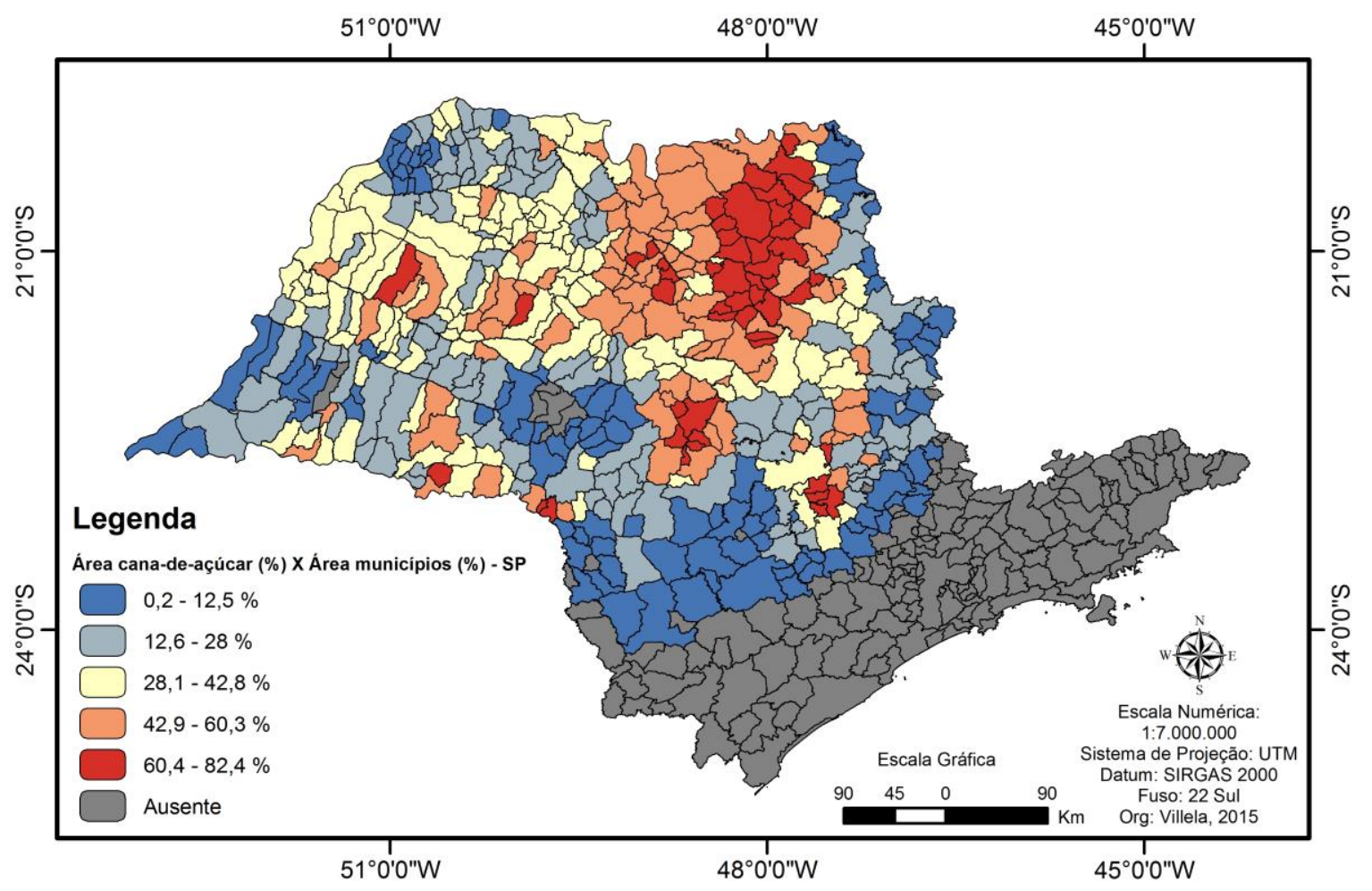

Figura 5. Percentual de área cultivada com cana-de-açúcar em relação a área dos municípios do Estado de São Paulo no ano de 2014. 
Analisando a Figura 4, verificou-se que 159 municípios dos 389 com a presença do cultivo em 2004, tinham $10 \%$ da área do seu território ocupada com cana-de-açúcar. Verificou-se também que 153 municípios apresentam ocupação de 10,1 a 40\% e 23 na faixa de 40,1 a 50\% da área. Constatou-se que em 38 municípios a ocupação varia de 50,1 a 70\%, e em 16, cerca de 4\% dos municípios, enquadram-se na faixa de 70,1 e 81,9\% de ocupação.

Já analisando a Figura 5, verifica-se que o cultivo se faz presente em 484 municípios, 95 a mais do que no ano de 2004. Comparando-se o ano de 2014 com 2004, observa-se uma redução no número de municípios com ocupação até $20 \%$. Por outro lado, constatou-se um aumento de aproximadamente $124 \%$ no número de municípios com ocupação de 20,1 a $50 \%$, passando de 104 para 233 em 2014. Nos municípios com ocupação variando de 60,1 a 70\%, também verificou-se um aumento, que passou de 38 para 71 municípios. No nível mais crítico, de 70,1 a $82,4 \%$ o aumento registrado foi de aproximadamente $62 \%$, passando de 16 para 26 municípios. Nota-se que a expansão ocorreu em novos municípios e nas áreas onde o cultivo já se fazia presente.

Dessa forma, devem-se considerar os impactos socioambientais causados pelo rápido avanço da cultura.

\subsection{Impactos Socioambientais}

O significativo aumento na produção de cana-de-açúcar levantou discussões acerca de problemas socioambientais ocasionados pelo avanço desta monocultura. Tais discussões têm como objetivo solucionar problemas existentes em áreas onde o cultivo já está presente e pretende também nortear o processo de expansão de forma a minimizar seus impactos em novas áreas.

Segundo Gallardo e Bond (2011) os impactos estão presentes em todas as etapas da produção da atividade canavieira e são listados pelos mesmos autores como sendo: poluição 
do ar, degradação do solo, erosão, poluição dos recursos hídricos, competição com culturas alimentares, pressão sobre áreas de vegetação nativa, perda de biodiversidade e condições de trabalho inadequadas.

A atividade canavieira impacta o ar em duas fases distintas em seu processo produtivo, que são: o emprego de queimadas como ferramenta de colheita e pelas emissões de poluentes como dióxido de Nitrogênio $\left(\mathrm{NO}_{2}\right)$ monóxido de carbono $(\mathrm{CO})$ e o material particulado, oriundos das chaminés das caldeiras (MACEDO; SEABRA; SILVA, 2008). A utilização da queimada tem como objetivo facilitar a colheita manual da cana e eliminar animais peçonhentos. Este tipo de prática compromete a qualidade do ar da zona rural e a saúde das populações urbanas, devido as emissões de altas concentrações poluentes, como material particulado, $\mathrm{CO}_{(\mathrm{x})}$ e $\mathrm{CH}_{4}$ (GOLDEMBERG; COELHO; GUARDABASSI, 2008). As queimadas também provocam alterações no microclima local, devido às mudanças no balanço de energia e fluxo de calor latente e sensível, ocasionadas pela alteração do albedo da superfície do solo (PEREIRA et al., 2009).

Alguns estudos como de Arbex et al. (2000); Lopes e Ribeiro (2006), avaliaram o efeito agudo da queima dos canaviais à saúde da população, que indicaram que neste período há maior incidência de visitas hospitalares, aumento no número de inalações e internações ocasionadas por doenças respiratórias nas cidades próximas aos canaviais. No Estado de Louisiana (EUA), Boopathy et al. (2002) verificaram a mesma tendência de aumento no número de atendimentos nos meses de ocorrência das queimadas.

No estado de São Paulo, o esforço para eliminar tal prática iniciou-se em 2002 com a Lei $\mathrm{N}^{\circ}$ 11.241(SÃO PAULO, 2002) que dispõe sobre a eliminação da queimada em áreas aptas a mecanização de forma gradativa, com metas para 2031. Em 2007, houve um avançou no sentido de eliminar as queimadas, após a assinatura do (Protocolo Verde SMA) de 
cooperação com produtores paulistas de cana-de-açúcar que antecipa a eliminação da queima para 2017.

Outra fonte de poluição do ar é por meio das chaminés das usinas, que emitem materiais particulados e NOx, oriundos dos processos ocorridos nas caldeiras. De acordo com Costa (2008), estudos aplicados à dispersão de poluentes em chaminés de usinas sucroalcooleiras, apresentaram quantidades de emissões muito próximas dos limites estabelecidos pela Resolução CONAMA Nº 003/1990 (BRASIL, 1990).

No solo, os impactos do cultivo de cana-de-açúcar estão associados a fatores como a erosão, compactação e contaminação. A erosão ocorre de forma mais acentuada durante os períodos intermediários, entre a colheita e o crescimento, no qual o solo fica exposto por alguns meses, e na fase inicial de conversão de culturas, onde grandes áreas de solo ficam expostas, deixando mais vulnerável à ação de agentes como chuvas intensas e ventos no solo.

A compactação do solo é provocada pelo intenso tráfego de máquinas pesadas nas fases de preparo e colheita, que causam alterações nas propriedades físicas do solo, como densidade e porosidade, resultando na diminuição da infiltração e que, consequentemente, contribui para os processos erosivos (MARTINELLI; FILOSO, 2008).

Garbiate et al. (2011) avaliaram a concentração de matéria orgânica e dos nutrientes ( $\mathrm{P}, \mathrm{K}, \mathrm{Ca}$ e $\mathrm{Mg}$ ) em três sistemas de colheita: manual e mecanizada em cana queimada e mecanizada em cana crua. Após aplicar uma chuva simulada de $60 \mathrm{~mm} \mathrm{~h}^{-1}$ durante $50 \mathrm{~min}$, constatou-se que as maiores concentrações de matéria orgânica e dos nutrientes foram verificadas no sistema de colheita mecanizada com cana queimada e as menores, sob o mesmo sistema com cana crua. Embora o tráfego das máquinas prejudique a qualidade física do solo, por outro lado os resíduos vegetais da colheita reduzem as perdas de matéria orgânica e nutrientes no solo e ameniza a degradação física do solo. 
Em um trabalho semelhante Sousa et al. (2012), avaliaram as perdas dos mesmos elementos em parcelas com $0,25,50,75$ e $100 \%$ de cobertura da palha da cana. Sob chuva simulada de $60 \mathrm{~mm} \mathrm{~h}^{-1}$ durante 65 minutos, constatou-se que as maiores perdas foram registradas nas parcelas com 0 e $25 \%$ e as menores nas com 75 e $100 \%$ de cobertura com a palha. Os autores concluíram que uma cobertura acima de $50 \%$ já reduz a perda de solo e de matéria orgânica, bem como diminuem a concentração dos nutrientes no sedimento erodido.

A contaminação do solo ocorre devido à aplicação inadequada por fertirrigação utilizando a vinhaça, subproduto da fabricação do etanol. Segundo Guagnoni, Nakao e Ribeiro (2003), a vinhaça tem potencial fertilizante com altas concentrações de $\mathrm{K}, \mathrm{Ca}, \mathrm{Mg}, \mathrm{S}$ e micronutrientes. No entanto, Silva, Griebeler e Borges (2007), alerta sobre o alto poder poluente, cerca de cem vezes mais poluentes que o esgoto doméstico, devido à grande quantidade de matéria orgânica, baixo $\mathrm{pH}$, alto poder corrosivo e alta demanda bioquímica de oxigênio (DBO).

No Estado de São Paulo a prática de fertirrigação deve atender à norma CETESB P4.231, que estabelece critérios e procedimentos para o armazenamento, transporte e aplicação da vinhaça.

Já nos recursos hídricos, os impactos são atribuídos à alta demanda hídrica na fase de processamento da cana e ao risco de contaminação dos corpos d'água. Os impactos relacionados ao uso são verificados na captação de rios e mananciais e no consumo demandado pela produção de etanol (SMEETS et al., 2006). Os autores também apontam para o aspecto da contaminação provocado pelos agroquímicos utilizados na lavoura e os compostos de alto teor orgânico gerados no processo de obtenção dos insumos.

Jacomini et al. (2011) avaliaram a contaminação dos rios Sapucaí, Pardo e MogiGuaçu por ametrina, em locais próximos do cultivo de cana-de-açúcar, onde o herbicida é muito utilizado. No rio Mogi-Guaçu foram detectados resíduos na água, biota e nos 
sedimentos. Para os rios Sapucai e Pardo verificou-se somente a presença nos sedimentos, que apresentaram altas concentrações nos três rios estudados.

Britto et al. (2011) também detectou ametrina nas águas superficiais do Rio Poxin, que é responsável pelo abastecimento de $27 \%$ da demanda do município de Aracajú - SE. Observa-se que as áreas de recarga passaram por um grande processo de substituição de vegetação nativa por atividade agropecuária sobre tudo pelo cultivo de cana-de-açúcar.

Corbi et al. (2006), avaliaram a presença de organoclorados e metais em 11 córregos na região central do Estado de São Paulo, situados na bacia do Rio Jacaré-Guaçu. As maiores concentrações dos elementos e dos organoclorados, foram detectados nos córregos adjacentes a áreas com o cultivo de cana-de-açúcar.

Para garantir o atendimento da crescente demanda gerada pelo bioetanol, muitas áreas vêm sendo incorporadas afim de atender o mercado interno e externo. A incorporação de novas áreas levanta a discussão sobre a questão de segurança alimentar. Cerqueira Leite et al. (2009) estimaram em seu estudo a substituição de 5\% da demanda de gasolina mundial por etanol, e concluíram que para conseguir suprir tal demanda o Brasil precisaria triplicar sua área de cultivo para 21 milhões de hectares. O estudo revelou também que se esta área fosse alocada em áreas de pastagens, ainda sobrariam cerca de 70 milhões de hectares disponíveis para pasto. Estas estimativas consideraram como sendo não aptas, áreas de proteção permanente e áreas destinadas a outras culturas, de modo a evitar competição com culturas alimentícias.

Em outra análise sobre os impactos do setor sucroalcooleiro nas culturas alimentícias, Gauder, Graeff-Honniner e Claupein (2011) constataram que a quantidade de terras não aparece como um fator limitante para a expansão da cultura canavieira. No entanto, Pimentel e Patzek (2007) ressaltam que o aumento da utilização do bioetanol cria uma situação de insegurança alimentar. 
Segundo Coelho et al. (2007) a substituição de culturas de gêneros alimentícios por cana-de-açúcar ocasiona uma pressão sobre áreas de vegetação natural. Glehn (2008) alerta que a expansão desta monocultura vem tomando espaços prioritários para a conservação da biodiversidade.

\subsection{Produção de sedimentos em Bacias hidrográficas}

A bacia hidrográfica é uma área de captação natural da água de precipitação que faz convergir o escoamento para um único ponto de saída. Ela é composta por um conjunto de superfícies, vertentes e de uma rede de drenagem formada por cursos de água que confluem até resultar um leito único no seu exutório (TUCCI, 2001).

A produção de sedimentos em uma bacia hidrográfica é proveniente dos processos erosivos que ocorrem nas vertentes, margens e no leito do canal principal e seus tributários (KNIGHTON, 1998).

Segundo Yang (1996), os fatores determinantes na produção de sedimentos são: intensidade e quantidade de precipitação; tipo de solo e formação geológica; uso do solo; topografia; taxa de erosão; drenagem; declividade; forma, tamanho e alinhamento dos canais e características dos sedimentos, tais como granulometria e mineralogia.

De acordo com Bordas e Semmelmann (2001) a produção de sedimentos divide-se em três regiões, sendo: Interflúvios ou vertentes, Leitos ou calhas e planícies aluviais ou várzeas. Os interflúvios ou vertentes, correspondem a área de captação e produção de sedimentos. Leitos ou calhas, tem como principal função a propagar os sedimentos produzidos pelas vertentes até o exutório da bacia. As planícies aluviais ou várzeas funcionam como áreas receptoras dos sedimentos produzidos a montante durante os períodos de cheia e como fornecedoras de sedimentos durante todo ano. 
Santos (2001) acrescenta que o alto curso corresponde a área de maior degradação na bacia, onde o rio transporta grandes quantidades de material grosseiro. $\mathrm{O}$ médio curso representa a área mais estável com pequenos acréscimos e redução do volume transportado que apresenta granulometria média. No baixo curso, observa-se o predomínio da deposição dos sedimentos, sendo transportado pelo rio somente os de granulometria fina.

Montgomery e Buffington (1997) citam que os processos geomorfológicos dominantes que controlam a produção, transporte e distribuição de sedimentos variam com a escala espacial. Em uma bacia grande, a produção de sedimentos não é controlada apenas pela erosão hídrica em terras aráveis, mas em grande parte por influxos pouco frequentes de sedimentos de deslizamentos de terra, fluxos de detritos e erosão das margens.

As taxas de produção de sedimento de uma bacia hidrográfica estão intimamente relacionadas ao uso e ocupação de seu entorno e as práticas de manejo empregadas. Desta forma, o desequilíbrio entre esses aspectos e os eventos climáticos extremos podem acentuar a produção de sedimentos, superando níveis produzidos de até um século em condições de equilíbrio natural (SIMÕES; COIADO, 2001).

Segundo Minella et al. (2007), os sedimentos em uma escala de bacia hidrográfica são originados de diferentes fontes, variando de acordo com o uso do solo. Desta forma, identificar a origem dos sedimentos torna-se indispensável para compreender as taxas de emissões, bem como auxiliar no manejo dos sedimentos erodidos.

Os danos relacionados aos processos de erosão, transporte e deposição de sedimentos são numerosos. Estes englobam a perda da fertilidade do solo, transporte e depósito de nutrientes e contaminantes, alterações na qualidade da água e destruição do habitat aquático, assoreamento de canais, portos, reservatórios além da redução na durabilidade de equipamentos de hidrelétricas (WILLIAMS, 1989; HOROWITZ, 2003; CARVALHO, 2008). 
Os problemas relacionados aos sedimentos são potencializados à medida que ocorre o desenvolvimento e ocupação do espaço geográfico, representando um grande desafio para a gestão dos recursos hídricos (SILVA; SCHULZ; CAMARGO, 2003).

Segundo Carvalho (2008), para lidar com os problemas relacionados aos sedimentos é preciso compreender a dinâmica hidrossedimentológica das bacias hidrográficas, a fim de garantir a conservação e a utilização dos seus recursos naturais.

Singh et al. (2008) destaca que estudos da produção de sedimentos são importantes para o planejamento de processos de conservação de solo e água, análise de sedimentação em reservatório, estudo de mudanças na morfologia do solo, água e projetos agrícolas.

Embora esteja claro a importância dos estudos relacionados aos sedimentos, no Brasil observa-se um grande atraso nas pesquisas em sedimentologia. A ausência destas informações compromete as etapas de planejamento e gestão dos recursos hídricos (CARVALHO, 2008).

\subsection{Modelos Preditivos de Erosão}

Tucci (2005, p.195) define modelo como sendo “[...] a representação de algum objeto ou sistema, numa linguagem ou forma de fácil acesso e uso, com o objetivo de entendê-lo e buscar respostas para diferentes entradas [...]”.

Segundo Moreira (2005) os modelos podem ser classificados sob diversos aspectos, tais como:

Tipos de variáveis (estocásticos ou determinísticos);

Tipos de relações entre essas variáveis (empíricos ou conceituais);

$\checkmark$ Forma de representação dos dados (discretos ou contínuos);

$\checkmark$ Existência ou não de relações espaciais (concentrados ou distribuídos);

$\checkmark$ Existência de dependência temporal (estacionários ou dinâmicos). 
Entre os tipos de modelos apresentados, os distribuídos destacam-se na modelagem de produção de sedimentos, pois permitem identificar de forma espacializada as regiões mais susceptíveis à erosão. Além disso, os modelos podem fornecer estimativas do aporte de sedimentos em uma bacia hidrográfica em função das mudanças de uso e ocupação do solo (SCHULTZ; SOUZA; SANTOS, 2011).

Entre os modelos existentes voltados a predição de erosão hídrica e de transporte de sedimentos, destacam-se:

$\checkmark$ Water Erosion Prediction Project - WEPP (FLANAGAN; NEARING, 1995);

$\checkmark$ Watershed Erosion Simulation Program-WESP (LOPES, 1987);

$\checkmark$ Kinematic Runoff e Erosion Model - KINEROS (WOOLHISER; SMITH; GOODRICH, 1990);

$\checkmark$ Chemicals Runoff and Erosion from Agricultural Management SystemsCreams (KNISEL, 1980);

$\checkmark$ Simulator of Water Resource in Rural Basin- SWRRB (ARNOLD; WILLIAMS, 1987);

$\checkmark \quad$ Soil and Water Assessment Tool-SWAT (ARNOLD et al., 1998).

Dentre esses modelos o SWAT tem papel de destaque no cenário internacional, por permitir inúmeras análises, sobretudo relacionadas as estimativas de escorrimento superficial e produção de sedimentos, sendo abordadas no presente estudo. Neste sentido, o modelo SWAT foi escolhido para este estudo, sendo apresentado a seguir uma descrição do modelo e algumas aplicações em âmbito nacional e internacional.

\subsection{Modelo SWAT}

O Soil and Water Assessment Tools (SWAT) é um modelo matemático que opera em escala de bacia hidrográfica, desenvolvido pelo Departamento de Agricultura dos Estados Unidos (USDA), (SWAT, 2014). O modelo foi desenvolvido para predizer os impactos das 
alterações no uso, tipo e práticas de manejo do solo, sobre o escoamento superficial e subterrâneo, produção de sedimentos, aporte de poluentes e qualidade na água em bacias hidrográficas, em um longo período de tempo (NEITSCH et al., 2009). O modelo SWAT possui base física, tendo como características ser distribuído e contínuo, o que permite analisar os processos físicos atuantes na bacia em um período de tempo estipulado pelo usuário, gerando séries temporais como dados de saída do modelo (TIM, 1996; GASSMAN et al., 2007).

A simulação dos processos hidrológicos é dividida em duas partes, sendo uma fase terrestre e a outra aquática. Nesta primeira fase, são controladas a quantidade de água e as cargas de sedimento, nutrientes e pesticidas que atingem o canal principal. Já a segunda fase está relacionada ao movimento da água, sedimentos, entre outros, pela rede de canais em direção à saída da bacia (NEITSCH et al., 2009).

Para realizar a simulação o modelo utiliza dados de entrada referentes às condições climáticas, propriedades do solo, topografia, uso e ocupação, práticas de manejo e vegetação. Tais dados são facilmente organizados devido à integração entre o SWAT e o sistema de informação geográfica Arcgis®, dando origem ao ArcSWAT (DI LUZIO; SRINIVASAN; ARNOLD, 2001). Após inserir os dados de entrada no modelo, automaticamente o SIG (Sistema de Informação Geológica) divide a bacia em sub-bacias de modo a agrupar as informações em Unidades de Resposta Hidrológica (HRU's), baseadas no tipo de solo, uso e cobertura do solo e em classes de declividade.

Esta divisão permite observar diferenças quanto à evapotranspiração e outras condições hidrológicas para diferentes combinações de tipo e uso do solo. O escoamento é calculado de forma separada para cada HRU e depois é programado para calcular o escoamento total da sub-bacia. Segundo Arnold et al. (1998), este procedimento confere 
maior precisão nas predições, além de fornecer uma maior descrição física do balanço hídrico na bacia.

O SWAT tem apresentado muita eficiência em estudos de avaliação dos recursos hídricos e problemas de fontes de poluição difusas em diversas condições ambientais e escalas em todo mundo (GASSMAN et al., 2007). O modelo foi aplicado com os mais variados enfoques e em inúmeros países, dentre eles: Estados Unidos, Holanda, Coréia, Suíça, Colômbia, Itália, Alemanha, Chile, Romênia, Iran, Vietnã, Filipinas e China.

Na Europa, estudos para quantificar os impactos relacionados a mudanças climáticas, utilizaram vários modelos, incluindo o SWAT em cinco diferentes bacias hidrográficas. Em outro estudo, o SWAT e outros nove modelos foram aplicados em dezessete bacias europeias (GASSMAN et al., 2007).

A aceitação da comunidade internacional pelo uso do modelo deve-se ao esforço de mais de 30 anos de modelagem conduzidos pela USDA, que ainda se mantém na busca do melhoramento contínuo de uma ferramenta robusta e versátil para análise de bacias hidrográficas. Isto é evidenciado pelas conferências internacionais anuais sobre o SWAT, que neste ano será realizada na Itália, na cidade de Sardinia.

No Brasil o modelo também vem sendo bastante utilizado, como mostra o trabalho de Garbossa et al. (2011) que levantou trabalhos realizados com o SWAT em bacias brasileiras no período de 1999 a 2010. Os resultados mostraram que entre artigos, teses e dissertações, somaram-se mais de setenta publicações, que conseguiram abordar os mais variados climas e comportamentos hidrológicos das bacias brasileiras. Após análise, concluise que de todos os trabalhos realizados, $43 \%$ foram aplicados para estimar a produção de sedimentos, $41 \%$ estimaram o escoamento superficial e $16 \%$ para nutrientes. Constatou-se também que $42 \%$ dos trabalhos foram realizados no sul do país, seguido por $32 \%$ realizados no sudeste e o restante nas demais regiões (GARBOSSA et al., 2011). 


\subsubsection{Equações do Modelo SWAT}

Segundo Neitsh et al. (2009) o modelo SWAT realiza as simulações hidrológicas na bacia hidrográfica, dividindo o ciclo hidrológico em duas fases, sendo terrestre e aquática. A fase terrestre controla a quantidade de água e cargas de sedimento, nutrientes e pesticidas que chegam até o canal principal. Na fase aquática relaciona-se ao movimento da água, sedimentos entre outros até o exutório da bacia (NEITSH et al.,2009).

A fase terrestre é baseada na equação do balanço hídrico:

$$
S W_{t}=S W+\sum_{i=1}^{t}\left(R_{t}-Q_{i}-E T_{i}-P_{i}-Q R_{i}\right) \quad \text { Equação } 1
$$

Onde SW (mm) é o conteúdo de água no solo, i é o tempo em dias para o período de simulação t (dias), e R (mm) a precipitação diária, Q (mm) escoamento superficial ou “runoff', ET é a evapotranspiração, P a percolação (mm) e QR (mm) o fluxo de retorno.

O modelo SWAT calcula o escoamento superficial pelo método do número da curva SCS (Soil Conservation Service):

$$
Q_{\text {surf }}=\frac{\left(R_{\text {day }}-0,2 \cdot S\right)^{2}}{\left(R_{\text {day }}+0,8 \cdot S\right)}
$$

Onde:

$\mathrm{R}_{\text {day }}$ : quantidade de chuva em um dia $(\mathrm{mm})$;

$\mathrm{Q}_{\text {surf }}$ : quantidade de escoamento superficial acumulado ou excesso de chuva (mm);

S : parâmetro de retenção. 
O valor de $\mathrm{S}$ varia conforme os diferentes tipos de solos e uso, e com a declividade do terreno, em função da variação de umidade no solo, sendo calculado por:

$$
S=25,4 \cdot\left(\frac{100}{C N}-10\right)
$$

Equação 3

CN: Número da curva para um determinado dia.

O valor de $\mathrm{CN}$ é determinado pelo SWAT diariamente, sendo estabelecido em função da permeabilidade, uso do solo e condições de umidade do solo, utilizado para predizer o escorrimento superficial. O CN varia de 1 a 100 , sendo que o limite superior representa condições de total impermeabilidade, convertendo toda precipitação em escorrimento. Já o limite inferior, retrata condições de um solo totalmente permeável (NEITSCH et al., 2009).

A evapotranspiração abarca todos os processos de transpiração e evaporação de água nas plantas e evaporação de água no solo. Ela pode ser estimada pelo SWAT por meio de três métodos:

\footnotetext{
$\checkmark$ Penman-Monteith;

$\checkmark \quad$ Priestley-Taylor;

$\checkmark$ Hargreaves-Samani.
}

De acordo com Minoti (2006) caso a evapotranspiração for inferior a quantidade de água livre nas plantas, o modelo considera como sendo iguais a evapotranspiração real e potencial (mm). Em situação oposta, o SWAT atribui que a quantidade de evaporação diária da água livre nas plantas (mm) será igual à quantidade inicial de água livre nas plantas (mm) e a quantidade final será nula.

De acordo com Neitsh et al. (2009) a percolação é calculada para cada camada do solo, sendo que este processo ocorre quando a quantidade de água excede a capacidade de campo 
para uma determinada camada de solo. O volume de água disponível para percolar a camada do solo deve atender às seguintes condições:

$$
\begin{array}{lll}
S W_{l y, \text { excess }}=S W_{l y}-F C_{l y} & \text { se } & S W_{l y}>F C_{l y} \\
S W_{l y, \text { excess }}=0 & \text { se } & S W_{l y}>F C_{l y}
\end{array}
$$

Onde:

$\mathrm{SW}_{\mathrm{ly}}$, excess: quantidade de água disponível para percolar em uma camada de solo em um determinado dia (mm);

$\mathrm{SW}_{\text {ly }}$ : quantidade de água em uma camada de solo, em um determinado dia (mm);

FCly: quantidade de água de uma camada de solo na capacidade de campo (mm).

Segundo os autores o cálculo da quantidade de água que é transferida de uma camada para outra, segue a metodologia de rota de armazenamento, conforme a equação:

$$
W_{\text {perc }, l y}=S W_{l y, e x c e s s} \cdot\left(1-\exp \left[\frac{-\Delta t}{T T_{\text {perc }}}\right]\right)
$$

Em que:

$\mathrm{W}_{\text {perc, ly }}$ : quantidade de água que efetivamente percola no dia $(\mathrm{mm})$;

$\Delta t$ duração do intervalo de tempo (h);

$\mathrm{TT}_{\text {perc }}$ : tempo de percolação entre as camadas (h).

O tempo gasto pela percolação é único para cada uma das camadas, sendo obtido por:

$$
T T_{\text {perc }}=\frac{S A T_{l y}-F C_{l y}}{K_{\text {sat }}}
$$

Em que:

$\mathrm{SAT}_{\text {ly }}$ :quantidade de agua no solo completamente saturado $(\mathrm{mm})$; 
$\mathrm{K}_{\text {sat: }}$ condutividade hidráulica saturada da camada $\left(\mathrm{mm} \cdot \mathrm{h}^{-1}\right)$.

O escoamento lateral é calculado de forma simultânea com a percolação, através de um modelo cinemático para o escoamento no sub-solo baseado na equação de balanço de massa, onde o segmento declive é utilizado como volume de controle (NEITSCH et al., 2009). O escoamento sub-superficial lateral é calculado pela equação:

$$
Q_{\text {lat }}=0,024 \cdot\left(\frac{2 \cdot S W_{l y \text { excess }} \cdot K_{\text {sat }} \cdot s l p}{\varphi_{d} \cdot L_{\text {hill }}}\right)
$$

Equação 6

Onde:

Qlat : escoamento lateral (mm.dia $\left.{ }^{-1}\right)$;

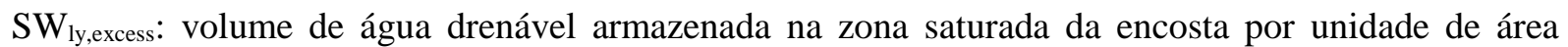
$(\mathrm{mm})$

$\mathrm{K}_{\text {sat: }}$ condutividade hidráulica do solo saturada $\left(\mathrm{mm} \cdot \mathrm{hr}^{-1}\right)$;

slp: declividade da encosta $(\mathrm{m} / \mathrm{m})$;

$\varphi_{d}:$ porosidade drenável do solo $(\mathrm{mm} / \mathrm{mm})$

$\mathrm{L}_{\text {hill: }}$ comprimento da encosta $(\mathrm{m})$.

De acordo com Neitsh et al. (2009) o SWAT calcula a produção de sedimentos, para cada HRU, por meio da Equação Universal de Perda de Solos Modificada (MUSLE) de (WILLIAMS, 1975). Esta equação é uma modificação da Equação Universal de Perda de Solo (USLE), desenvolvida por (WISCHMEIER; SMITH, 1965). A USLE, prediz a média anual bruta de erosão como uma função da força da chuva, sendo que na MUSLE o fator de força da chuva é substituido pelo fator de escoamento, resultando em uma melhora a previsão de produção de sedimentos. A MUSLE é representada pela seguinte equação: 
Sed $=11,8 \cdot\left(Q_{\text {surf }} \cdot q_{\text {peak }} \cdot \text { area }_{H R U}\right)^{0,56} \cdot K_{U S L E} \cdot C_{U S L E} \cdot P_{U S L E} \cdot L S_{U S L E} \cdot C F R G \quad$ Equação 7

Onde:

Sed: Produção de sedimento em um dia (ton);

$\mathrm{Q}_{\text {surf: }}$ Volume de escoamento superficial ( $\left.\mathrm{mm}_{\mathrm{H} 2 \mathrm{O}} / \mathrm{ha}\right)$;

$q_{\text {peak: }}$ Taxa de pico de escoamento superficial $\left(\mathrm{m}^{3} / \mathrm{s}\right)$;

area $_{\mathrm{HRU}}$ : Área da HRU (ha);

$\mathrm{K}_{\mathrm{USLE}}:$ Fator de erodibilidade da EUPS;

$\mathrm{C}_{\text {USLE }}$ : Fator de cobertura e de menejo da EUPS;

$\mathrm{P}_{\text {USLE: }}$ Fator de suporte de prática da EUPS;

LS $_{\text {USLE }}$ : Fator topográfico da EUPS;

CFRG: fator de fragmentação esparsa.

\subsubsection{Aplicações do Modelo SWAT}

Neste item são apresentados alguns trabalhos nacionais e internacionais com aplicação do modelo SWAT.

Minoti (2006) realizou uns dos primeiros trabalhos utilizando o modelo SWAT no Brasil. O autor quantificou os processos de erosão, produção de sedimentos e alguns parâmetros do ciclo hidrológico de um compartimento da bacia hidrográfica do rio MogiGuaçu-SP. As estimativas de perda de solo anual foram estimadas pela Equação Universal de Perda de Solos (EUPS) e a produção de sedimentos e os parâmetros do balanço hídrico a partir do SWAT. O estudo permitiu quantificar a perda de solo e estimar a produção de sedimentos e componentes do ciclo hidrológico para alguns cenários propostos para as microbacias estudadas. 
Lelis et al. (2012) utilizou o SWAT para estudar o escoamento superficial e a perda de solo na bacia hidrográfica do ribeirão São Bartolomeu, que está localizado na cidade de Viçosa, Zona da Mata Mineira. Adicionalmente, o estudo verificou o potencial natural de perda do solo, análise de sensibilidade, avaliação de outros cenários a partir do atual, e simulações do reflexo das alterações climáticas, modificando variáveis de temperatura e pluviosidade. O modelo foi calibrado e validado em campo por meio de dados de dez parcelas que foram instaladas para coletar o solo perdido e o volume escoado. Tais dados apresentaram resultados satisfatórios, alcançando valores do coeficiente de eficiência (COE) de 0,953 para produção de sedimentos e 0,999 para o escoamento superficial. Após esta etapa realizou-se a análise de discretização da bacia, na qual concluiu-se que para a área de estudo a maior ou menor subdivisão não influenciava nos resultados. Por fim, simulou-se cenários com alterações de uso e clima, nos quais constatou a grande sensibilidade do modelo as mudanças que ocorrerem relacionadas ao clima.

Kuwajima (2012) aplicou o modelo no reservatório do Lobo (Itirapina, SP) com objetivo de avalia-lo como ferramenta de suporte para análise da estimativa de assoreamento de barragens. A simulação foi realizada para os períodos de 1977 até 1985 e de 1996 até 2006 e após a calibração utilizando algoritmo SUFI2, obteve-se o aporte de sedimentos para os dois períodos. Os resultados para o primeiro período não demonstraram-se satisfatórios, devido as inconsistências de dados de vazão utilizados e pela limitação na discretização da bacia, em consequência do mosaico ser muito fragmentado em razão da quantidade e disposição espacial dos usos. Já para o segundo período simulado, obteve-se resultados satisfatórios, comprovando a capacidade do modelo como ferramenta de avaliação de geração e aporte de sedimento em reservatórios.

Arroio Júnior (2013), utilizou o SWAT com objetivo de realizar um diagnóstico da produção de sedimentos e seu transporte na bacia do Rio Itaqueri, localizado nos municípios 
de Brotas e Itirapina - SP. Além da simulação, também foram realizadas o monitoramento da qualidade da água, a quantificação da carga sólida em suspensão e a determinação da granulometria do material de leito em seções de amostragem localizadas nos principais tributários do reservatório. Verificou-se por meio das simulações que ocorrem na bacia, áreas com diferentes comportamentos hidrossedimentológicos, com locais aonde a produção anual média de sedimentos chegou a 18ton/ha e outras próximas de zero. Constatou-se que o Rio Itaqueri contribuiu com $65 \%$ dos sedimentos que chegam ao reservatório e observou-se também os maiores valores de carga sólida em suspensão.

Villela et al. (2014) simularam a produção de sedimentos para a bacia do Rio Quilombo, localizada no município de São Carlos - SP. O uso da bacia é voltado predominantemente para atividade agropecuária com elevada presença de áreas de cultivo de cana-de-açúcar e pastagens. Os resultados apontaram para taxas de produção que variam de 0 a 19 ton. ha $^{-1}$. ano ${ }^{-1}$ sendo os maiores valores identificados nas sub-bacias localizadas na porção sul da microbacia, onde encontra-se as maiores altitudes. Nestas áreas observam-se apenas alguns fragmentos de vegetação densa protegendo os maiores declives, estando o restante do território ocupado por pastagens. Tais características acabam por gerar uma maior perda de solo em eventos de chuva intensos, e, consequentemente, maior produção de sedimentos nestas sub-bacias.

Galharte, Villela e Crestana (2014) aplicaram o modelo SWAT para estimar a produção de sedimentos em dois cenários gerados pelo modelo de simulação espacial CLUES (Conversion of Land USE and its Effects at Small Region Extent) na micro-bacia do ribeirão das Guabirobas, (São Carlos, SP), para o ano de 2025. As simulações no CLUE-S foram orientadas visando à expansão da cana-de-açúcar para o primeiro cenário e o segundo para expansão da laranja. Após as simulações do SWAT para os dois cenários, constatou-se que a 
produção de sedimentos foi mais significativa no cenário em que houve a expansão da cana de-açúcar.

Memarian et al. (2014) aplicaram o modelo SWAT para verificar os impactos nas condições hidrológicas provocados por alterações no uso e ocupação do solo na bacia de Hulu na Malásia. Eles partiram dos anos de 1984, 1990, 1997 e 2002 para analisar o passado e a partir do mapa de uso e ocupação de 2006, elaboraram o cenário de 2013. Utilizando um modelo de autômatos celular de Marcov, elaborou o Cenário de 2020. Após as simulações concluiu-se que o modelo respondeu bem a calibração para a descarga de água no período simulado de 1997 até 2008. No entanto, para carga de sedimentos o modelo foi considerado aceitável apenas para o período de 1997 a 2004, a simulação SWAT com base no cenário futuro (2020) mostrou aumento significativo no escoamento superficial mensal e cargas de sedimentos mensal e recarga de águas subterrâneas.

Gessesse, Bewket e Bräuning (2014) aplicaram o simulador para analisar a mudança no escoamento superficial e erosão do solo em resposta à dinâmica de uso e cobertura na bacia de Modjo, (Etiópia). Após as simulações os autores verificaram um aumento de 14,2\% no escoamento superficial e $37 \%$ na produção de sedimentos se comparado com o ano de 1973. Eles constataram também que $95 \%$ da área da bacia tinham registrado altas taxas de perda de solo.

Fang et al. (2013) utilizaram o modelo para quantificar os efeitos das mudanças do uso e cobertura do solo durante o período de 1970 até 2010 sobre os recursos hídricos na bacia do rio Laohahe, (Nordeste da China). Os resultados revelaram que diversas mudanças de cobertura da terra ocorreram na bacia, e que a mudança mais importante foi à conversão entre as classes de cobertura vegetal de terras agrícolas, áreas florestais e pastagens. Os autores verificaram que a mudança nessas três classes afeta significativamente os elementos hidrológicos e que o aumento de área de vegetação reduz o escoamento superficial. 
Zhang e Wang (2014), modelaram os efeitos das mudanças de uso e ocupação do solo na bacia hidrográfica Lizixi, uma típica área agrícola da bacia do rio Jialing localizada na China. O modelo SWAT foi utilizado para estimar o escorrimento superficial e sedimentos diários a partir desta bacia, com 20 anos de dados coletados (1975 a 1995). Inicialmente, aplicou-se o modelo visando obter valores aceitáveis para os coeficientes de correlação $\left(\mathrm{R}^{2}\right)$ e o coeficiente Nash - Sutcliffe (ENS) nos procedimentos de calibração e validação. Em seguida, utilizou-se o modelo para determinar quais tipos de cultivos podem ser produzidos com as menores taxas de produção de sedimentos e erosão. Os resultados indicaram que o cultivo de trigo produz menos sedimentos, seguido por batata-doce e milho. O estudo também avaliou a influência da inclinação do relevo na erosão. Após dividir a bacia em 4 regiões, sendo categorizadas as áreas com declives de $0-5^{\circ}, 5-15^{\circ}, 15-25^{\circ}$ e maior que $25^{\circ}$, constatou-se que as áreas com declividade superior a $25^{\circ}$ apresentaram os maiores valores de erosão, sendo recomendado a substituição de campos agrícolas por áreas de florestas ou pradarias nestes locais.

Babel, Shrestha e Perret (2011) avaliaram o impacto do aumento da produção de biocombustíveis na hidrologia da microbacia Khlong Phlo, situada na região Leste da Tailândia. Utilizando o modelo SWAT estimou-se os impactos nos componentes do balanço hídrico para os cenários de expansão do cultivo de óleo de palma (biodiesel) mandioca e cana-de-açúcar para o etanol. Os resultados indicaram que a mandioca apresentou maior pegada hídrica do que os outros dois cultivos, considerados eficientes em termos de água. A simulação da expansão do óleo de palma indicou uma pequena alteração de 0,5 a $1,6 \%$ na evaporação e rendimento de água de 0,5 a - 1,1\% e um aumento de 1,3-51,7\% na quantidade de nitrato para as águas de superfície. Já para os cultivos de etanol, teria uma redução de $(0,8$ a $11,8 \%$ na evapotranspiração e aumentaria o rendimento de água em 1,6 - 18,0\%, que consequentemente, levaria a um aumento de 10,9-91,5\%, na produção de sedimentos, 1,9- 
$44,5 \%$ de nitrato e 15,0-165,0\% do fósforo total nas águas superficiais. Com base nos resultados os autores concluíram que a expansão do cultivo de palma afetaria a qualidade da água da microbacia, enquanto que os componentes do balanço hídrico e a qualidade da água seriam afetados por ambos cultivos do etanol. Por fim, conclui-se que a expansão dos biocombustíveis teria um impacto negativo na qualidade da água da microbacia.

Nobert e Jeremiah (2012), aplicaram o modelo SWAT para comparar o impacto das mudanças de uso e ocupação sobre o escorrimento superficial na bacia do Rio Wami, localizada na Tanzânia. Após calibrar e validar o modelo foram estimados a taxas de escorrimento superficial para os cenários de uso e ocupação dos anos de 1987 e 2000 . Os resultados mostraram que do cenário de 1987 para o de 2000, houve uma redução de 1,4\% na área de floresta, um aumento de 3,2 \% na área agrícola e um aumento de 2,2 na área urbana. As simulações revelaram que houve uma redução nas vazões média de 166,3 milímetros em 1987, para 165,3 milímetros em 2000.Quanto ao escorrimento superficial, verificou-se um aumento de $11 \%$ passando de 59,4 milímetros em 1987 para 65,9 milímetros em 2000 e o fluxo de base diminuiu de 106,8 milímetros e 99,4 mm em 1987 e 2000, respectivamente. Observa-se que a mudança de uso e ocupação ocorrida entre 1987 e 2000, alteraram o escorrimento superficial e o escoamento de base da bacia.

Homdee, Pongput e Kanae (2011) aplicaram o modelo SWAT para avaliar os impactos da mudança de uso e ocupação na produção de água da bacia do Rio Chi na Tailândia. Cinco cenários foram analisados, sendo entre esses a conversão de área florestal, a expansão de terras agrícolas, a mudança de campos de arroz para culturas energéticas e dois cenários que envolvem a conversão de terras para arroz e plantação de cana de açúcar. Os resultados indicam que os diferentes cenários contribuem para vários efeitos no rendimento anual e sazonal de água e evapotranspiração. A conversão de área de floresta e terrenos agrícolas apresentou pequenas mudanças nos fluxos de água e evapotranspiração (ET). A 
substituição de campos de arroz por plantação de cana reduziu os fluxos de água e aumentou a ET em quase 5,0\% na estação seca. Particularmente, no caso da expansão dos arrozais e campos agrícolas, constatou-se pequenas mudanças no fluxo anual e na ET, mas o efeito mais significativo ocorre em fluxos sazonais.

Lessa et al. (2013) avaliaram a produção de sedimentos na parte inicial da bacia do Rio Pardo, Botucatu-SP, durante o período de 1994 a 1999. O modelo SWAT possibilitou estimar a produção de sedimentos para a bacia que contabilizou uma produção média de 33,86 ton.ha ${ }^{-1} \cdot$ ano $^{-1}$ ao longo dos seis anos de estudo. Constatou-se que nas sub-bacias predominantemente ocupadas com o cultivo de cana-de-açúcar, a taxa de produção de sedimentos variou de 5 a 10 ton.ha ${ }^{-1} \cdot$ ano $^{-1}$.

Machado e Vetorazzi (2003) utilizaram o modelo SWAT para estimar a produção de sedimentos do ribeirão Marins, Piracicaba-SP, no biênio 1999/2000. Após a calibração do modelo, os autores constataram que as áreas ocupadas com o cultivo de cana-de-açúcar produziram as maiores taxas de sedimentos, que variaram de 6,3 a 11,3 ton.ha ${ }^{-1} \cdot$ ano $^{-1}$.

Fukunaga et al. (2015) avaliaram durante o período de 1991 a 2000 o potencial do modelo SWAT em reproduzir as vazões médias diárias da bacia do Rio Itapemirim, localizado no Estado do Espirito Santo- ES. Os resultados sem os procedimentos de calibração apresentaram respectivamente os seguintes valores do coeficiente Nash - Sutcliffe (ENS) e do percentual de tendências (PBIAS), -0,38 e -24\%. Após a calibração, realizada no período de 1991 a 1995 foram obtidos os valores de 0,75 para (ENS) e 11\% para o (PBIAS). Na etapa de verificação que abrangeu o período de 1996 a 2000, os valores foram de 0,67 para (ENS) e 22\% para (PBIAS). Quanto aos parâmetros utilizados na calibração verificou-se maior sensibilidade dos parâmetros relacionados a características físicas do solo e variáveis de águas subterrâneas. 
Can et al. (2015) utilizaram o modelo SWAT para avaliar os impactos dos diferentes cenários de uso e ocupação do solo em processos hidrológicos na bacia Fuhe, situada na Bacia Poyang, leste da China. Ao todo 12 parâmetros foram calibrados com dados de vazão mensal observadas para o 1982-1988 e verificado para 1991-1998. Os autores constataram que os valores dos coeficientes de correlação $\mathrm{R}^{2}$ e Nash - Sutcliffe (ENS), variaram entre 0,88 e 0,94, para os períodos de calibração e verificação. Quanto aos cenários, concluiu-se que as áreas com florestas têm maior capacidade de conservar a água em relação às pastagens. Observou-se também que a urbanização exerce maior influência nas taxas de escorrimento superficial, rendimento de água e na evapotranspiração.

Nyeko (2015) aplicou o modelo SWAT na bacia de Aswa, localizada na região norte de Uganda. O estudo utilizou diferentes técnicas para estimar vários parâmetros inexistentes para a bacia, como radiação solar, condutividade hidráulica do solo, água disponível no solo e albedo. O modelo foi calibrado manualmente utilizando uma série histórica mensal, obtendo resultados satisfatórios com coeficiente de determinação $\mathrm{R}^{2}$ de 0,61 e coeficiente de Nash Sutcliffe (ENS) de 0,47. Para o período de validação foram obtidos $R^{2}$ e ENS de respectivamente 0,56 e 0,64 . A calibração do modelo mediante a carência de dados existes para a bacia ressalta o potencial de aplicabilidade do modelo SWAT mesmo em bacia com limitações de dados.

Andrade, Mello e Beskow (2013), aplicaram o modelo SWAT na bacia do Jaguara, que possui uma área de $32 \mathrm{~km}^{2}$ e está localizada no Alto Rio Grande - MG. Com o trabalho objetivou-se calibrar e verificar as vazões médias para a bacia durante o período de diário de 01/01/2006 a 31/08/2009. O desempenho da simulação foi medido com base no coeficiente de Nash-Sutcliffe ENS, sendo obtidos os valores de 0,66 e 0,87 nas etapas de calibração e verificação respectivamente. 
Baltokoski et al. (2010) aplicaram o SWAT para estimar a vazão média e as quantidades de fósforo (P) total nas microbacias dos rios Conrado e Pinheiro, afluentes do Rio Pato Branco, localizado em Pato Branco - PR. As simulações foram realizadas no período de 01/01/2003 a 31/12/2005, sendo obtidos para a vazão valores de coeficiente de Nash-Sutcliffe ENS para a microbacia do Conrado igual a 0,68 e 0,70 para a microbacia do Pinheiro, desempenho considerado satisfatório. Para as simulações referente ao fósforo total foram obtidos (ENS) de 0,27 para a microbacia do Conrado e 0,36 para a do Pinheiro, valores também considerados satisfatórios. 


\section{MATERIAIS E MÉTODOS}

\section{1 Área de Estudo}

A microbacia está localizada no município de Votuporanga, na região Noroeste do estado de São Paulo entre as coordenadas UTM 7739088 m a 7728280 m N e 601902 m a 612427 m E (Figura 6).

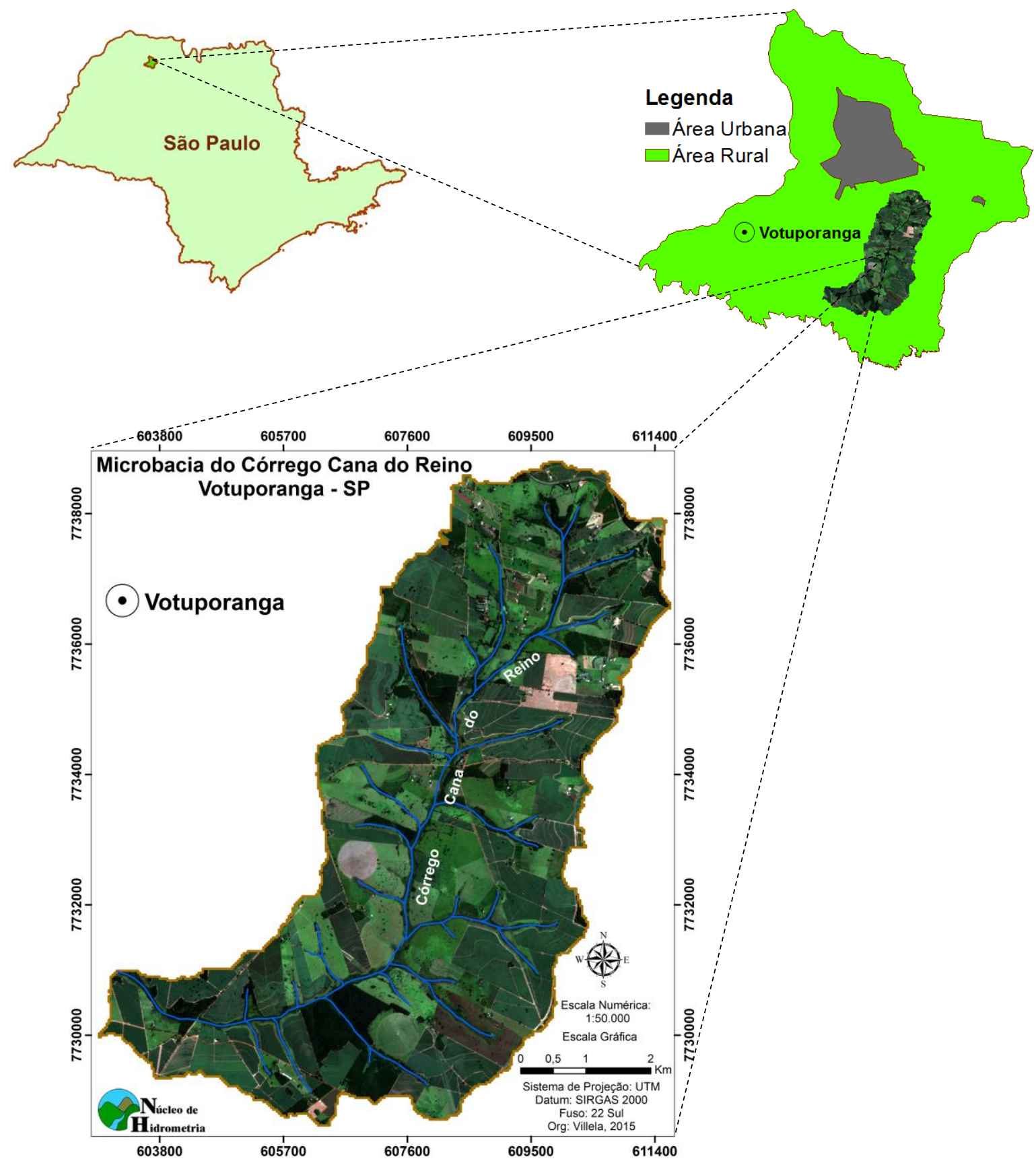

Figura 6. Localização da microbacia do Córrego cana do Reino (Votuporanga - SP). 
Ela está inserida na Unidade de Gerenciamento de Recursos Hídricos - UGRHI 18, onde ocupa parcialmente as sub-bacias do Alto e Médio São José dos Dourados (IPT, 2008). Sua área de drenagem é de aproximadamente 4.216 ha, valor que corresponde a $10 \%$ da área territorial do município. O córrego Cana do Reino é o principal tributário da microbacia com extensão de 12,58 km, com deságue no Córrego do Cabrito.

A escolha da área de estudo foi baseada em aspectos como: disponibilidade de dados requeridos pelo modelo SWAT, existência de dados de monitoramento de vazão para possibilitar a comparação dos resultados simulados com os dados observados, além do contexto de expansão da cana-de-açúcar na microbacia. Considerando estes aspectos, elaborou-se critérios de seleção de modo a atender as demandas do estudo, os quais são listados a seguir:

$\checkmark$ Existência de um posto fluviométrico com dados diários no período do estudo;

$\checkmark$ Expansão da cana-de-açúcar no período de 2004 a 2014;

$\checkmark$ Existência de estação meteorológica próxima à área de estudo;

Existência de postos pluviométricos próximos a microbacia.

\subsection{Elaboração do Banco de Dados}

\subsubsection{Modelo de Elevação}

Neste item são apresentados os dados de entrada necessários para realização das simulações pelo modelo SWAT, bem como a descrição do processo de aquisição e os procedimentos metodológicos para a construção do banco de dados.

O Modelo Digital de Elevação (MDE) utilizado para descrever as variações altimétricas da microbacia, foi adquirido em formato digital do levantamento aerofotogramétrico realizado pelo projeto de atualização cartográfica do estado de São Paulo (Projeto Mapeia São Paulo, 2010/2011). O MDE está disponível na escala de 1:10.000, 
pertencendo a classe A do padrão de exatidão cartográfico altimétrico nacional. As quadrículas correspondentes a microbacia do Córrego Cana do Reino, possuem a seguinte numeração: SF-22-X-A-II-4-SE, SF-22-X-A-III-3-SO, SF-22-X-A-VI-1-NO e SF-22-X-A-V2-NE.

Após a aquisição dos dados, deu-se início a elaboração do mosaico e o recorte da área de interesse, a partir de ferramentas dos módulos Data Management tools e Analysis Tools, disponíveis no software ArcMap 9.3 (ESRI, 2014). O MDE serviu de base para a elaboração da carta clinográfica da microbacia, através da utilização dos módulos 3D Analysis Tools e Raster Surface, por meio da ferramenta Slope.

\subsubsection{Pedologia}

Segundo o mapa exploratório de solos apresentado pelo IPT (1990), os solos existentes na UGRHI - 18 são: Latossolos Roxos, Latossolos Vermelho Escuros, Podzólicos Vermelho Escuros e Podzólicos Vermelho Amarelos. Na microbacia encontram-se dois tipos de solos, os Podzólicos Vermelho Amarelos eutróficos, que ocupam mais de 90\% da área e os Podzólicos Vermelho Amarelos eutróficos abruptos que aparecem em uma menor área ao norte da microbacia. No entanto, o uso desse mapeamento não foi possível, devido a sua escala de elaboração (1:250.000) ser incompatível, com uma escala representativa exigida pelo estudo.

Diante desse contexto, iniciou-se uma busca na literatura e em órgãos públicos, por mapeamentos do município de Votuporanga - SP, que tivessem escala compatível para a realização do estudo. Ao fim do levantamento, constatou-se a existência de um único mapeamento, realizado na Estação Experimental do IAC, a qual não está inserida na área de estudo. O mapeamento foi elaborado em nível detalhado na escala de (1:10.000), junto com a caracterização físico-hídrica dos solos (IAC, 1999). 
A ausência de mapeamentos com a escala exigida pelo estudo, motivou a elaboração de um levantamento pedológico para a microbacia do córrego Cana do Reino.

O levantamento foi realizado por meio de uma parceria entre o Núcleo de Hidrometria, uma usina situada em Sebastianópolis do Sul e a empresa Athenas Consultoria Agrícola de Jaboticabal - SP. A seguir são descritas as etapas metodológicas aplicadas na elaboração do levantamento.

\subsubsection{Levantamento Pedológico}

Para o levantamento pedológico da microbacia, adotou-se a metodologia descrita em Embrapa (1995), constando de trabalhos de escritório, campo e laboratório. O tipo de levantamento para a microbacia foi o de alta intensidade, com faixa preferencial de escala de publicação de 1:50.000 a 1:100.000.

\subsubsection{Trabalhos De Escritório}

Esta etapa iniciou-se com a elaboração do planejamento amostral para a realização do levantamento pedológico. Nesse planejamento foram utilizados os seguintes dados:

$\checkmark$ Modelo digital de Elevação na escala de 1:10.000 referente às quadrículas: SF-22X-A-II-4-SE, SF-22-X-A-III-3-SO, SF-22-X-A-VI-1-NO e SF-22-X-A-V-2-NE, (Emplasa, 2013);

$\checkmark$ Ortofotos na escala 1:25.000 referente às quadrículas SF-22-X-A-II-4-SE, SF-22X-A-III-3-SO, SF-22-X-A-VI-1-NO e SF-22-X-A-V-2-NE, (Emplasa, 2013);

$\checkmark$ Informações de levantamentos pré-existentes fornecidos pela usina;

$\checkmark$ Uso e ocupação do solo referente ao ano de 2014, que foi elaborado nesse estudo;

$\checkmark$ Carta clinográfica, elaborada nesse estudo. 
Após a organização da base cartográfica, realizou-se uma análise preliminar mediante a fotointerpretação da área com ênfase em separar as unidades de relevo. O resultado da fotointerpretação, cruzados com os demais dados cartográficos citados acima, permitiu definir os locais das sondagens a trado e coleta das amostras. Ao todo foram definidos 10 pontos de amostragem, distribuídos pela microbacia, de forma a preencher as áreas onde não haviam informações de solos. Ao concluir as etapas de campo e de laboratório, foi realizado o tratamento dos dados, bem como a plotagem dos pontos amostrados nas fotos aéreas, para efetuar a delimitação dos solos. A última fase da etapa de escritório, consiste na elaboração do material cartográfico junto com as informações de classificação dos solos.

\subsubsection{Trabalhos De Campo}

Nos trabalhos de campo foi realizada uma campanha de coleta de solos nos 10 pontos estabelecidos. Em cada ponto foram coletadas três amostras de solos nas profundidades de 0 a $20 \mathrm{~cm}, 20$ a $40 \mathrm{~cm}$ e 80 a $100 \mathrm{~cm}$, resultando em um total de 30 amostras. As coletas foram feitas utilizando os seguintes materiais.

$\checkmark$ Trado Holandês do tipo caneco;

$\checkmark$ Sacos plásticos com identificação do código e coordenadas do ponto;

$\checkmark$ Bandeja para o manuseio das amostras de solos;

$\checkmark$ Receptor GPS modelo Garmin Montana ${ }^{\mathrm{TM}} 650$.

Com as coordenadas dos 10 pontos de amostragem inseridas no GPS, foi possível chegar ao local de cada ponto definido e efetuar as coletas. As coordenadas dos pontos de coletas e de todo trajeto percorrido nos trabalhos de campo foram registradas pelo GPS (Figura 7). 

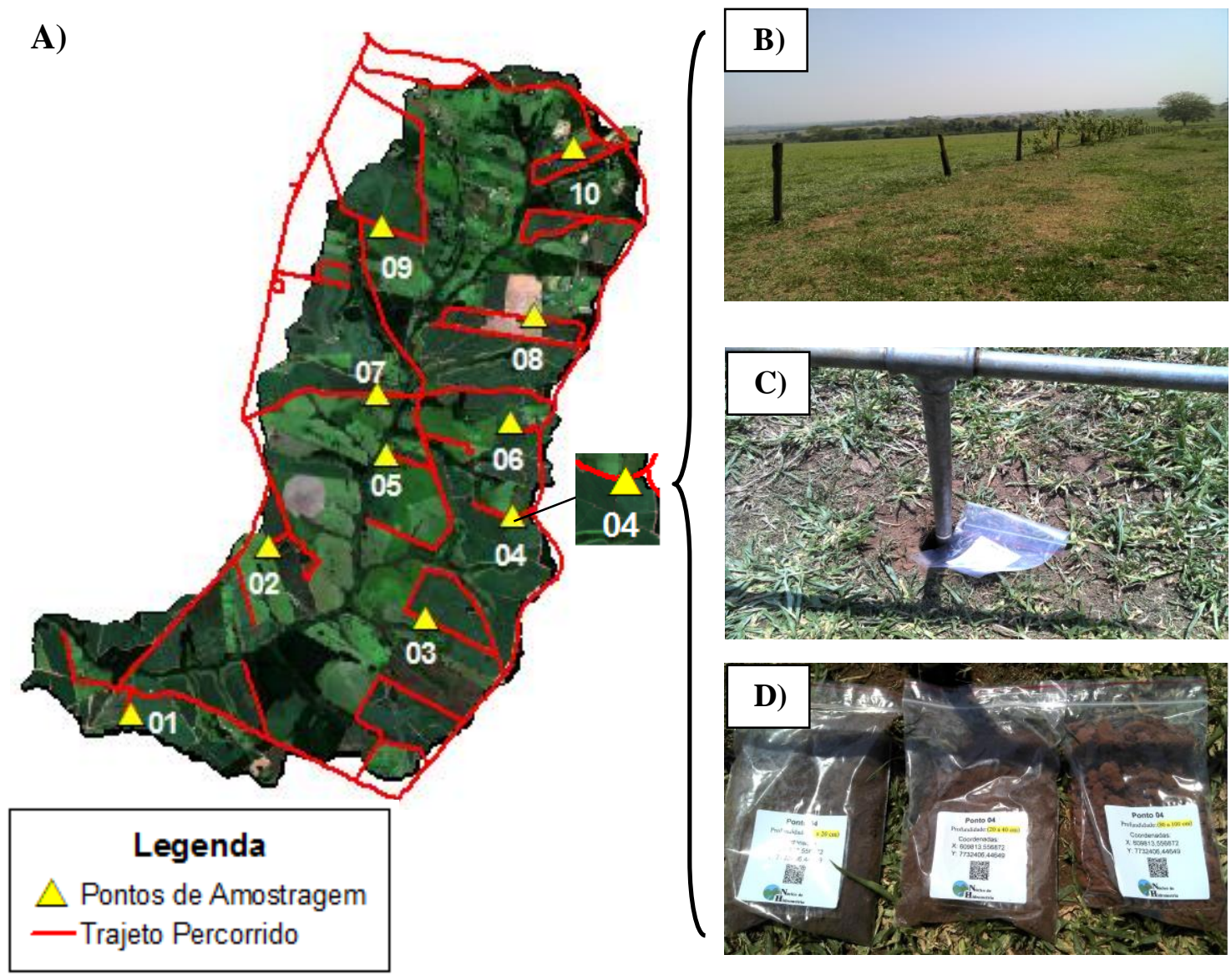

Figura 7. A) Mapa do trajeto e dos pontos de amostragem da coleta de solos; B) Foto ilustrando o entorno do ponto de amostragem $n^{\circ} 4$; C) Sondagem utilizando trado no ponto ${ }^{\circ} 4$ e D) Amostras de solos coletadas em três profundidades para o ponto $n^{\circ} 4$.

Após a coleta dos solos as amostras foram encaminhadas para as análises laboratoriais realizadas pela empresa Athenas Consultoria Agrícola e Laboratório, de Jaboticabal - SP.

\subsubsection{Trabalhos De Laboratório}

Nesta etapa, as 30 amostras foram submetidas aos ensaios de $\mathrm{pH} \mathrm{CaCl2}$, Matéria Orgânica, Fósforo (Resina), Cálcio, Magnésio, Potássio, H+Al (SMP), Alumínio, Enxofre, $\mathrm{SB}, \mathrm{CTC}, \mathrm{Al} \%$ e V\%, além da análise textural utilizando o método descrito por Embrapa (1997).

O laboratório em que foram feitas as análises possui certificação de qualidade, confirmados pelo IAC e Embrapa. Os resultados das análises são apresentados nos Anexos A e B. 


\subsubsection{Características Físicas Do Solo}

O SWAT demanda uma série de dados relacionados as características físicas dos solos, para que possa realizar as simulações hidrológicas. De acordo com (NEITSCH et al. 2009) os parâmetros exigidos são:

I.) Número de camadas de solo (NLAYERS);

II.) Grupo Hidrológico (HYDGRP);

III.) Máxima profundidade da raiz no perfil do solo (SOL_ZMX);

IV.) Porosidade do solo (ANION_EXCL)

V.) Profundidade das camadas de solo (SOL_Z);

VI.) Densidade (SOL_BD);

VII.) Capacidade de água disponível (SOL_AWC);

VIII.) Teor de carbono orgânico (SOL_CBN);

IX.) Condutividade hidráulica saturada (SOL_K);

X.) Teores de argila, silte, areia e fragmentos de rocha;

XI.) Albedo (Sol_ALB);

XII.) Fator erodibilidade do solo (fator K da EUPS).

Com exceção dos parâmetros: Número de camadas de solo (NLAYERS), Grupo Hidrológico (HYDGRP), máxima profundidade da raiz no perfil do solo (SOL_ZMX) e Porosidade do solo (ANION_EXCL), os demais parâmetros devem ser específicos para cada camada de solo.

Excetuando os dados de carbono orgânico (SOL_CBN) e o Albedo (Sol_ALB), que foram estimados por fórmulas recomendadas pelo manual do Modelo SWAT, os demais parâmetros foram obtidos de trabalhos da literatura e por levantamento em campo. A Tabela 1 apresenta os nomes dos parâmetros e a fontes de onde foram obtidos. 
Tabela 1. Parâmetros de solos exigidos pelo Modelo SWAT.

\begin{tabular}{ll}
\hline \multicolumn{1}{c}{ Parâmetros de Entrada } & \multicolumn{1}{c}{ Fonte } \\
\hline I.) Número de camadas de solo (NLAYERS) & Baldissera, (2005) \\
\hline II.) Grupo Hidrológico (HYDGRP) & Sartori et al. (2004) \\
\hline $\begin{array}{l}\text { III.) Máxima profundidade da raiz no perfil do solo } \\
\text { (SOL_ZMX) }\end{array}$ & Baldissera, (2005) \\
\hline IV.) Porosidade do solo (ANION_EXCL) & IAC, (1999); Baldissera, (2005) \\
\hline V.) Profundidade das camadas de solo (SOL_Z) & Baldissera, (2005); IAC, (1999) \\
\hline VI.) Densidade (SOL_BD) & IAC, (1999); \\
\hline VII.) Capacidade de água disponível (SOL_AWC); & Baldissera, (2005) \\
\hline $\begin{array}{l}\text { VIII.) Teor de carbono orgânico (SOL_CBN); } \\
\text { IX.) Condutividade hidráulica saturada (SOL_K); }\end{array}$ & $\begin{array}{l}\text { Athenas, (2014); Romanowicz et al. } \\
\text { (2005) Manual SWAT }\end{array}$ \\
\hline $\begin{array}{l}\text { X.) Teores de argila, silte, areia e fragmentos de } \\
\text { rocha; }\end{array}$ & Athenas, (2014) \\
\hline XI.) Albedo (Sol_ALB); & Biesbrouck, (2002) Manual SWAT \\
\hline XII.) Fator erodibilidade do solo (fator K da EUPS). & $\begin{array}{l}\text { Mannigel et al. (2002); Oliveira et } \\
\text { al. (2007) }\end{array}$ \\
\hline
\end{tabular}

O parâmetro SOL_CBN foi estimado pela equação utilizada por Romanowicz et al. (2005).

$$
\operatorname{orgC}=\frac{\mathrm{MO}}{1,7924}
$$

Em que:

MO: Matéria Orgânica.

Os valores MO para o cálculo orgC foram extraídos de Athenas, (2014).

O valor do albedo Sol_ALB foi estimado pela seguinte equação:

$$
\text { SOL_ALB }=0,6 / \exp \left(0,4^{*} \text { SOL_CBN }\right)
$$


Em que:

SOL_ALB = albedo do solo úmido, em \% e;

SOL_CBN = matéria orgânica na superfície do solo, em \%.

Baseado em Biesbrouck, (2002) o manual do SWAT apresenta os seguintes valores de referência:

$\checkmark$ Areia seca: $0,35-0,45$

$\checkmark$ Areia úmida: $0,20-0,30$

$\checkmark$ Solo escuro: $0,05-0,15$

$\checkmark$ Solo cinza úmido: $0,10-0,20$

$\checkmark$ Solo argiloso claro seco: $0,20-0,35$

$\checkmark$ Solo arenoso seco: $0,25-0,45$

\subsubsection{Uso e Ocupação do Solo}

Os mapas de uso e ocupação referentes aos anos de 2005 e 2014, utilizados no estudo, foram gerados a partir de imagens de satélite dos sensores LandSat -5 e LandSat -8 . Os sensores foram escolhidos por apresentarem resolução espacial condizente com a escala do trabalho, relacionado ao uso e ocupação do solo. Para o ano de 2005, selecionou-se uma imagem do sensor LandSat - 5, de (órbita e ponto: 222/74, com passagem na data 15/08/2005 que recobre a microbacia Cana do Reino. A imagem foi adquirida gratuitamente do catálogo do Instituto Nacional de Pesquisas Espaciais (INPE, 2014).

Para o ano de 2014 foi utilizada uma imagem do sensor LandSat - 8, devido o sensor LandSat -5 ter sido desativado em 2013. A imagem foi adquirida gratuitamente do United States Geological Survey (USGS), a qual possui órbita e ponto: 222/74, com passagem na data $08 / 08 / 2014$. 
A elaboração dos mapas de uso e cobertura do solo passou por duas etapas, sendo à primeira, referente à montagem e composição das bandas e o georreferenciamento das imagens, e na segunda, os procedimentos de interpretação e edição dos mapas. Para a imagem LandSat - 5 foram montadas as composições das bandas de falsa cor (5/4/3), sobre RGB e para LandSat -8 , as bandas (6/5/4). As imagens foram georreferenciadas utilizando o software de processamento de imagem Envi 4.7 (ITT-VIS) com o método imagem-imagem, associando-se a pontos de fácil reconhecimento na imagem de referência e na imagem a ser registrada, utilizando 15 pontos de controle distribuída por toda a imagem. A imagem de referência corresponde a cena S-22-20 da base de dados GeoCover (GLCF, 2014), que disponibiliza, gratuitamente, um mosaico de imagens LandSat que foram corrigidas geometricamente.

Na segunda etapa foi utilizado o software ArcView 9.3 (ESRI, 2014), para editar os mapas de uso e ocupação, perante a interpretação visual das imagens LandSat. Para auxiliar na interpretação das imagens, foi feito a sobreposição do mapeamento das áreas ocupadas com cana-de-açúcar, realizado pelo projeto Canasat (INPE, 2014).

O mapa de uso e cobertura do solo referente ao ano de 2014, foi verificado após a visita de campo na área de estudo, realizada em outubro de 2014 (Figura 8). 


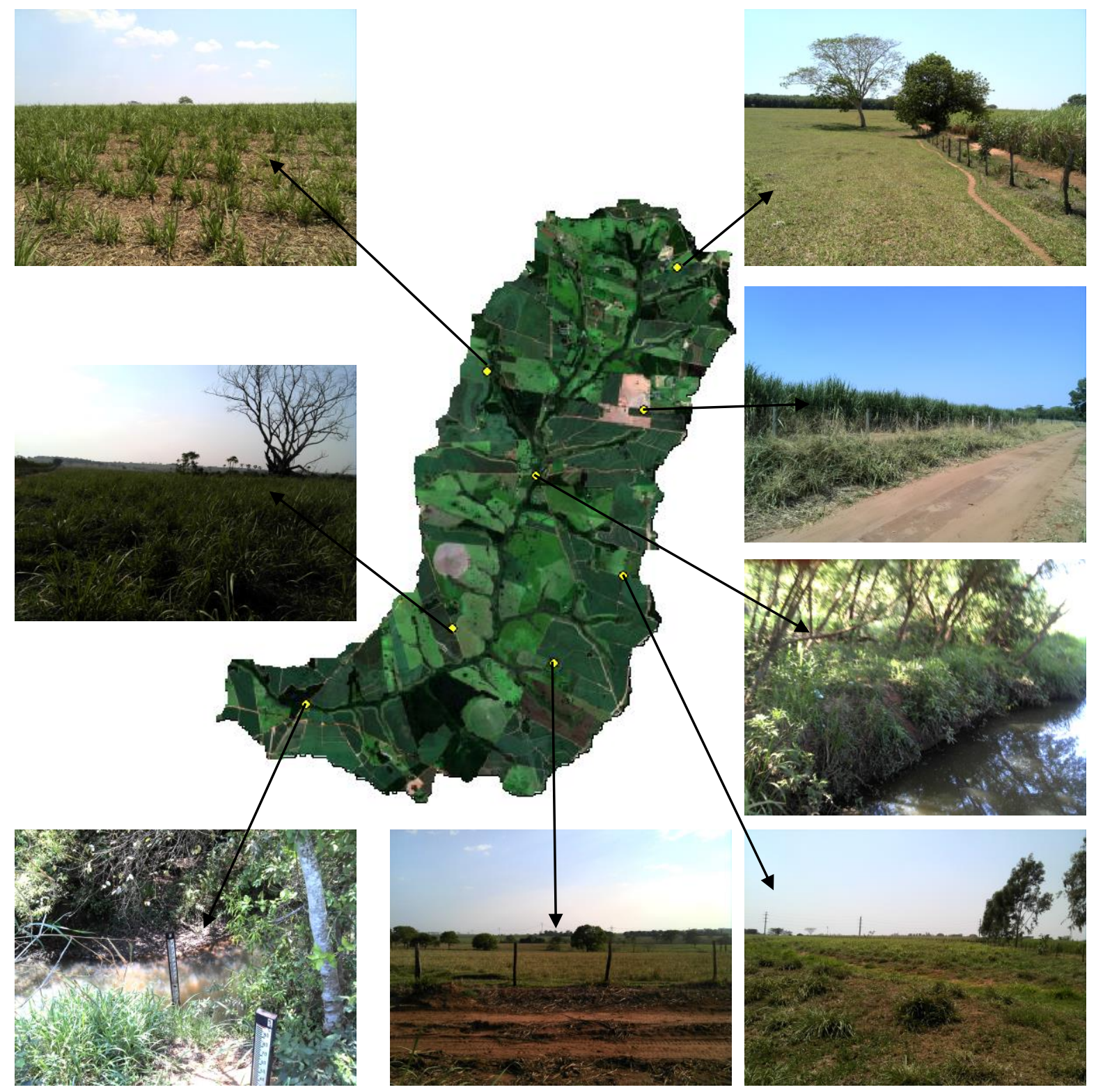

Figura 8. Visita de campo da microbacia córrego Cana do Reino, Votuporanga - SP.

\subsubsection{Dados Tabulares de Uso do Solo}

Além dos mapas de uso e ocupação do solo, o SWAT demanda informações específicas para cada classe de uso. Por se tratar de um número grande de informações, e não existir uma base de dados nacional com esses dados, buscou-se enquadrar os usos existentes na microbacia, com os tipos de uso disponíveis na base de dados do SWAT.

O enquadramento das classes de uso da microbacia, com as classes existentes no modelo SWAT são apresentados na Tabela 2. 
Tabela 2. Enquadramento das classes de uso e ocupação da microbacia com as classes do banco de dados do SWAT.

\begin{tabular}{cc}
\hline Classes de Uso na Microbacia & Classes de Uso do Banco de dados do SWAT \\
\hline Pastagem & Pasture (PAST) \\
Cana-de-Açúcar & Sugarcane (SUGC) \\
\hline Vegetação & Forest-Mixed (FRST) \\
\hline Outras Culturas & Agricultural Land-Generic (AGRL) \\
\hline Infraestrutura & Residential-Low Density (URLD) \\
\hline Seringueira & Rubber Trees (RUBR) \\
Milho & Corn (CORN)
\end{tabular}

\subsubsection{Dados Climáticos}

O modelo SWAT requer dados climáticos diários e mensais. No período diário são exigidos os seguintes dados: às médias ou somas diárias dos fatores: precipitação $\left(\mathrm{mm}_{2} \mathrm{O}\right)$, temperatura mínima e máxima $\left({ }^{\circ} \mathrm{C}\right)$, umidade relativa do ar $(\%)$, radiação solar $\left(\mathrm{MJ} / \mathrm{m}^{2}\right.$.dia) e velocidade do vento (m/s) (NEITSCH et al., 2009). Já no período mensal, o SWAT demanda os seguintes dados: média mensal da temperatura máxima diária (TMPMX); média mensal da temperatura mínima diária (TMPMN); desvio padrão para a temperatura máxima diária de cada mês (TMPSTDMX); desvio padrão para a temperatura mínima diária de cada mês (TMPSTDMN); média mensal da precipitação total (PCPMM); desvio padrão para a precipitação diária no mês (PCPSTD); probabilidade de dias úmidos seguidos de dias secos para determinado mês (PR_W1); probabilidade de dias úmidos seguidos de dias úmidos para determinado mês (PR_W2); média mensal de dias de precipitação (PCPD); média de radiação solar diária para um determinado mês (SOLARAV); média diária do ponto de orvalho para determinado mês (DEWPT) e média diária da velocidade do vento para determinado mês (WNDAV). Além desses dados, é preciso inserir as coordenadas geográficas e altitude das estações (NEITSCH et al., 2009).

Os valores a serem inseridos podem ser obtidos a partir de registros observados ou podem ser gerados pelo modelo. Neste caso, na ausência ou falta dos dados diários, o SWAT permite calculá-los por meio do gerador climático WXGEN, a partir dos dados de 
precipitação (SHARPLEY; WILLIAN, 1990). Tal procedimento não foi necessário nesse estudo, pois todos os dados diários encontram-se disponíveis.

Os dados climáticos referentes à microbacia foram obtidos da estação meteorológica automática, marca Campbell Scientific, instalada no interior da área experimental do Instituto Agronômico de Campinas (IAC), localizada no município de Votuporanga - SP.

A estação (Figura 7) está situada nas coordenadas (597.494,709 m E, 7.737.643,198 m $\mathrm{N}$ e $470 \mathrm{~m}$ de altitude), a $13 \mathrm{~km}$ da microbacia. Ela possui uma série histórica de 13 anos, referente ao período de 2002 a 2014. Estes dados foram obtidos através de um contato pessoal com o setor responsável pela coleta desses dados.

O posto pluviométrico B6-032 do Departamento de Águas e Energia Elétrica (DAEE) também foi incorporado à base de dados climáticos, pois contém uma série de dados completas e está inserida dentro da microbacia.

\subsubsection{Dados Fluviométricos}

No âmbito da modelagem hidrológica, os dados fluviométricos são utilizados para realizar o ajuste e verificação dos parâmetros dos modelos. Portanto, ressalta-se a importância de se trabalhar com dados consistentes, de modo a evitar que informações tendenciosas ou inconsistentes, sejam transferidas para o ajuste e prognóstico (TUCCI, 2001).

Alguns trabalhos realizados com o modelo SWAT não conseguiram avançar para as etapas de calibração e validação, devido à ausência dos dados de vazão. Para superar esta limitação, adotou-se como critério obrigatório para a escolha da área de estudo, a existência de uma série de dados diários sem falhas, de no mínimo 10 anos. Atendendo a esses requisitos, os dados fluviométricos utilizados nas etapas de calibração e validação da modelagem nesse estudo, foram extraídos do posto 6B - 012 que é monitorado pelo DAEE. O posto 6B - 012 está localizado nas coordenadas UTM 604.495,233 m E, e 7.730.200,47 m N, 
próximo ao exutório da bacia. Os dados são obtidos por meio de leituras diárias de réguas limnimétricas instaladas no ponto de medição.

No presente estudo, foram utilizados um total de 11 anos de dados contínuos, compreendendo o período de 01/01/2004 até 31/12/2014. Esses dados serviram de referência para avaliar a qualidade das simulações executadas, e para realizar os procedimentos de calibração e verificação.

A Figura 9 apresenta a localização da estação climatológica do IAC e dos postos pluviométrico B6 - 032 e fluviométrico 6B - 012 monitorados pelo DAEE.

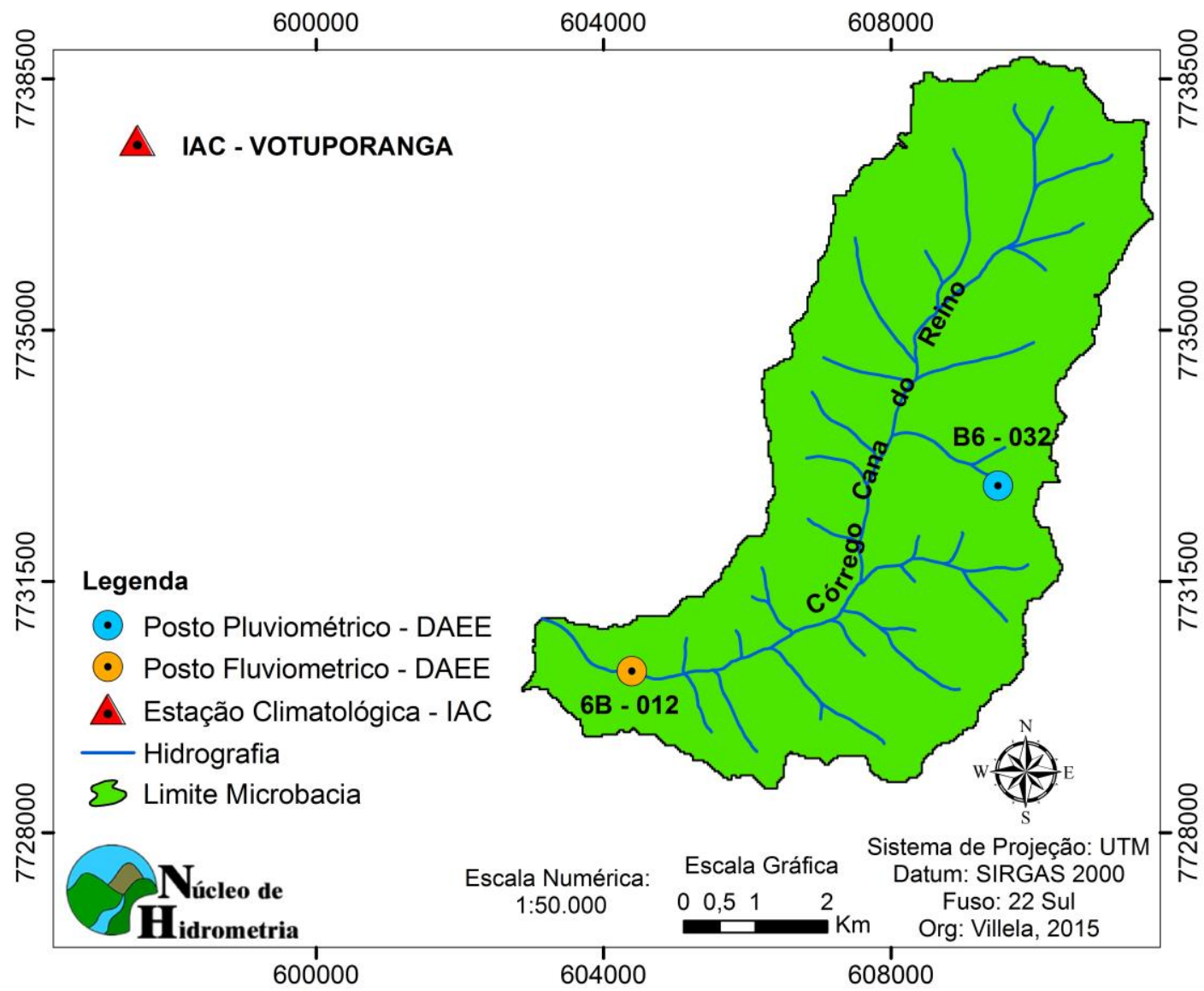

Figura 9. Localização da estação climatológica do IAC - Votuporanga e dos postos de monitoramento pluviométrico e fluviométrico do DAEE. 


\subsection{Etapas de Execução}

Após o preparo de todos os dados de entrada do modelo SWAT (Planos de informações/dados alfanuméricos), dá-se início ao processo de inserção dos mesmos no modelo. Os dados são inseridos a partir de uma interface entre o SWAT e o ArcGis, denominado ArcSWAT (DI LUZIO; SRINIVASAN; ARNOLD, 2001). Nesse estudo utilizou-se o ArcSWAT versão 2009.93.7b, compatível com o ArcMap 9.3, cujo grupo de pesquisa possui a licença de uso.

De posse dos dados, a primeira etapa a ser executada é a delimitação da bacia e das sub-bacias. Para realizar esse processo, deve-se inserir o MDE no módulo Watershed Delineator do SWAT (Figura 10). O modelo permite que as sub-bacias sejam definidas de duas formas, sendo a primeira por um limite definido pelo usuário e a segunda pela inserção da rede de drenagem. Nesse estudo, optou-se por adicionar a rede de drenagem, de modo a obter maior detalhamento das sub-bacias. Após inúmeros testes de tentativa e erro, chegou-se a um arranjo de sub-bacias, de tamanhos razoavelmente proporcionais e com exutório compatível ao posto fluviométrico.

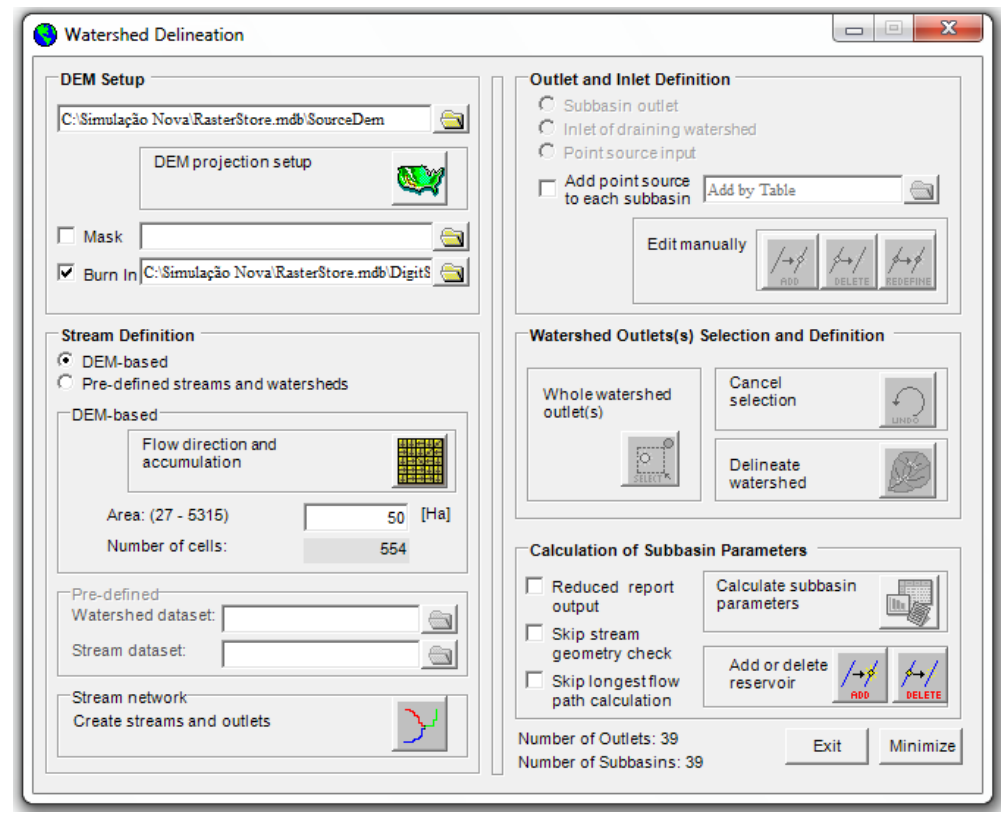

Figura 10. Interface do Módulo Watershed Delineator do ArcSWAT 2009.93.7b. 
O próximo e último passo dessa etapa é indicar o ponto do exutório da bacia, para que através dessa referência seja gerado o limite da bacia. Com a delimitação pronta, foram calculados os parâmetros morfológicos de cada sub-bacias e dos rios existentes.

\subsubsection{HRU}

Depois da delimitação da bacia e sub-bacias e inserir os dados pedológicos e climáticos no banco de dados do SWAT, dá-se início ao processo de definição das Unidades de Respostas Hidrológicas (HRU). As HRU são unidades dentro das sub-bacias que apresentam combinação exclusiva de tipo de solo, declividade e uso do solo. Essa abordagem permite uma análise mais detalhada dos processos simulados, pois são calculados separadamente para cada HRU e depois somados para determinar o total da sub-bacia.

Para poder definir as HRU, antes é preciso inserir os mapas de uso do solo e tipo de solo, mais a configuração das classes de declividade, no módulo Land use/Soil/Slope Definition. Esse procedimento exige que os dados das características do solo e do uso estejam inseridos na base de dados do SWAT, pois o modelo irá reclassificar os mapas de acordo com os dados tabelados. Quanto a configuração da declividade, optou-se por trabalhar com 3 classes, variando de $0 \%$ a $5 \%$, de $5 \%$ a $8 \%$ e $8,1 \%$ até o valor limite. A opção por apenas 3 classes de declividade, deve-se ao predomínio do relevo suave-ondulado na microbacia. Desse modo, inserindo um número superior, seriam geradas classes com áreas muito pequenas.

O resultado da reclassificação e sobreposição dos planos de informação inseridos nesse módulo, fornece as combinações que irão definir as HRU's. De acordo com Minotti (2006), o SWAT dispõe de duas opções para gerar as HRU's, que são: HRU Dominante e a HRU Múltipla. A primeira utiliza como critério para definição, a predominância dos aspectos do tipo de uso, tipo de solo e classes de declividade em termos de área, ou seja, a combinação com maior extensão é adotada para toda a área da sub-bacia, 
eliminando as demais. Já a opção das HRU múltiplas, gera combinações de tipo de solo, uso e declividade, mediante a valores que são atribuídos pelo usuário, podendo ser em área ou porcentagem, dos três aspectos utilizados para fornecer as HRU's. A definição e escolha por qual tipo de configuração será utilizada para gerar as HRU's é feita no Módulo HRU Definition (Figura 11).

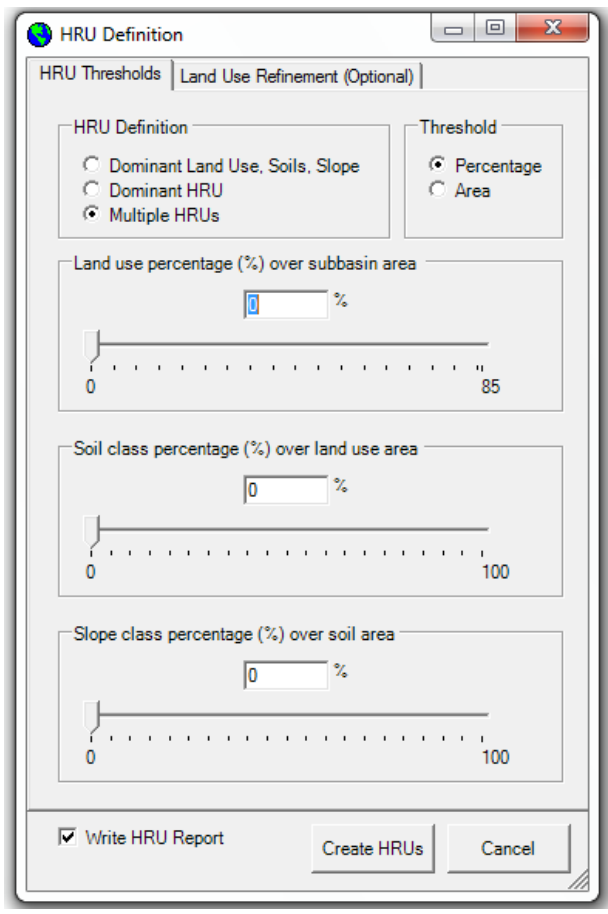

Figura 11. Interface do Módulo HRU Definition do ArcSWAT 2009.93.7b.

Nesse estudo, optou-se por trabalhar com HRU múltiplas para preservar o maior detalhamento da área de estudo. Pois trata-se de uma área relativamente pequena, com pouca variabilidade dos aspectos utilizados para definir as HRU's. Neste sentido, adotou-se $5 \%$ de grau de exclusão para cada plano de informação, eliminando combinações com área inferior a 5\% de área, para cada sub-bacia. Ao término do processo de definição das HRU's, o SWAT gera um relatório contendo a área e o percentual de cada uso, tipo de solo e classes de declividade por sub-bacia. 


\subsubsection{Entrada dos dados climáticos}

A próxima etapa consiste na inserção dos dados tabulares referente a precipitação, temperatura máxima e mínima, umidade, radiação solar e velocidade do vento. Os dados climáticos compreendendo o período de 01/01/2002 a 31/12/2014 foram inseridos no SWAT através da interface Waether Data Definition (Figura 12).

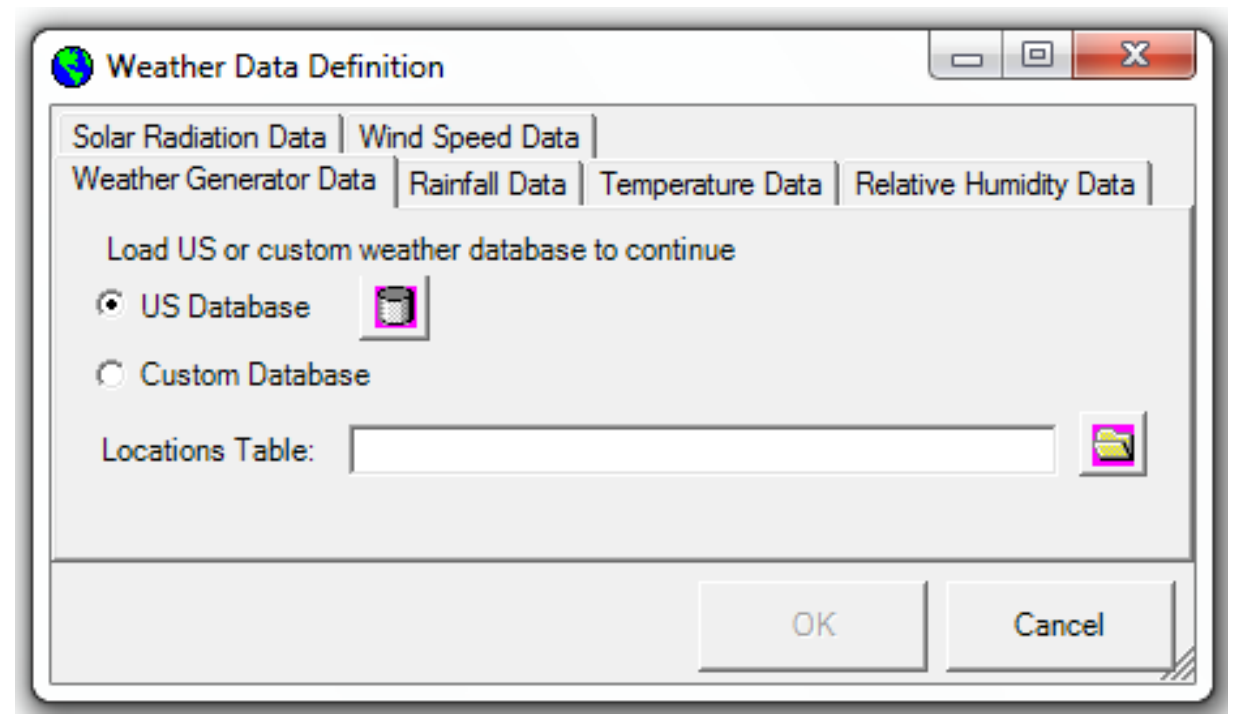

Figura 12. Interface Weather Data Definition.

\subsubsection{Simulação}

Após inserir todos os dados exigidos pelo modelo e concluir as configurações de entrada, pôde-se avançar para a etapa de execução do modelo. As simulações realizadas nesse estudo utilizaram um período contínuo de 13 anos, tendo início em 01/01/2002 até 31/12/2014. O período utilizado para o aquecimento do modelo (warm up) foi de 2 anos (2002 a 2003).

Inicialmente, o modelo foi executado com o objetivo de analisar o comportamento dos resultados de vazão gerados por essa simulação. A análise comparativa entre os dados simulados e os observados no posto fluviométrico, serviu de parâmetro para aplicar ou não os procedimentos de calibração e verificação. Com os resultados dessa análise, verificou-se uma 
boa aderência entre os valores simulados e observados, no entanto, não foi possível eliminar as etapas de calibração e validação, para ajustar o modelo.

As simulações foram executadas para os anos de 2005 e 2014, a fim de comparar os efeitos da mudança de uso e ocupação, decorrentes da expansão da cana-de-açúcar, nos aspectos hidrossedimentológicos da microbacia. O mapa de uso de 2005, retrata o cenário que antecede a expansão da cana-de-açúcar na microbacia, sendo esta ocupada por grandes áreas de pastagem. Já o mapa de uso de 2014 representa o cenário de expansão do cultivo na microbacia, que ganhou força a partir do ano de 2004, alcançando um crescimento, superior a $300 \%$ até o ano de 2014.

Com o modelo calibrado, realizou-se as simulações para estimar as taxas de escorrimento superficial e produção de sedimentos para os cenários de 2005 e 2014. As simulações foram executadas durante o período de 2004 a 2014. Como medida de comparação, decidiu-se utilizar um ano base, de modo a fornecer as mesmas condições climáticas para ambos cenários. Para escolha do ano base adotou-se como critério selecionar um ano dentro do período simulado que apresentasse valores mais próximos da média anual de precipitação para todo o período simulado. Após análise dos dados, verificou-se que o ano de 2011 é o que mais se aproxima da média total do período simulado.

\subsubsection{Análise de Sensibilidade Calibração e Verificação}

Segundo Arnold et al. (2012), o processo de calibração pode ser efetuado de três formas: manualmente, pelo módulo de auto calibração do SWAT ou pelo SWAT-CUP, que foi utilizado nesse estudo.

O SWATCUP é um software de domínio público, que realiza os procedimentos de análise de sensibilidade, calibração, validação e análise de incerteza para as simulações do modelo SWAT (ABBASPOUR, 2012). O software dispõe dos algoritmos GLUE 
(Generalized Likelihood Uncertainty Estimation), ParaSol (Parameter Solution), SUFI2 (Sequential Uncetainty Fitting) e MCMC (Markov Chain Monte Carlo), para realizar os procedimentos.

A primeira etapa do processo de calibração e verificação envolve a seleção dos parâmetros mais sensíveis para a bacia hidrográfica (ARNOLD et al., 2012). Segundo os autores, os parâmetros são selecionados por meio do conhecimento especializado e/ou análise de sensibilidade. No caso desse estudo, a escolha dos parâmetros para a análise de sensibilidade e calibração, baseou-se em (ARNOLD et al., 2012). A análise de sensibilidade e a calibração da modelagem desse estudo, foram realizadas pelo software SWATCUP2012, por meio do algoritmo Sequential Uncertainty Fitting (SUFI-2) (ABBASPOUR et al., 2004). O SUFI-2 representa uma ferramenta robusta, aplicada nas etapas de calibração e análise de incertezas do modelo SWAT (STRAUCH et al., 2012). Para Abbaspour (2007), o algoritmo apresenta como principal vantagem, a possibilidade de trabalhar com um número grande de variáveis, além de combinar a otimização da função objetivo e a análise de incerteza.

O SWATCUP realiza a análise de sensibilidade de forma global e individual. Na análise global a sensibilidade dos parâmetros é definida pelo cálculo do sistema linear de regressão múltipla. A significância relativa de cada parâmetro é identificada através de um $t$ test, sendo a sensibilidade definida pelas mudanças médias na função objetivo. Esta definição foi obtida através do resultado das alterações em cada parâmetro, ao passo que todos os outros parâmetros também são alterados. Em uma aproximação linear, determina-se a sensibilidade relativa, fornecendo informações parciais acerca da sensibilidade dos parâmetros do modelo na função objetivo (ABBASPOUR, 2012).

$\mathrm{Na}$ análise de sensibilidade global os resultados são apresentados por meio dos testes estatísticos $t$-stat e p-value. Para o t-stat quanto maior for seu valor, mais sensível é o 
parâmetro. Já no teste de $p$-value, quanto mais próximo o valor estiver de zero, maior será sua significância.

Quanto a análise de sensibilidade individual, esta apresenta a sensibilidade da mudança do parâmetro na variável em análise, mantendo todos os outros parâmetros constantes. A desvantagem desse método é o desconhecimento do valor constante dos outros parâmetros, tendo em vista que a sensibilidade de um parâmetro depende do valor de outro (ABBASPOUR, 2012).

A análise de sensibilidade individual foi feita com os parâmetros mais sensíveis identificados pela análise de sensibilidade global. Após concluir as análises de sensibilidade, deu-se início as etapas de calibração e verificação. Segundo Arnold et al. (2012) o processo de calibração consiste em ajustar os parâmetros do modelo, de modo a obter maior conformidade entre os dados observados e simulados.

Para avaliar o desempenho da modelagem em representar a realidade, as simulações foram submetidas as seguintes análises estatísticas: coeficiente de determinação $\left(\mathrm{R}^{2}\right)$, coeficiente de Nash-Sutcliffe (NSE) e o Percentual de tendências (PBIAS). Essas funções objetivo, são essências no processo de calibração de modelos hidrológicos, pois servem de parâmetro para o algoritmo de otimização definir a qualidade da modelagem hidrológica. Segundo Celeste e Chaves (2014), o papel das funções objetivo em modelagem hidrológica é o de minimizar ao máximo a diferença entre os valores simulados e observados.

O coeficiente de determinação $\left(\mathrm{R}^{2}\right)$ apresenta o nível de colinearidade entre os valores observados e simulados. $\mathrm{O}$ valor de $\mathrm{R}^{2}$ é sempre um número positivo entre 0 e 1 , sendo que, quanto maior for o $\mathrm{R}^{2}$ melhor será o poder de explicação da reta de regressão (LAPPONI, 2005). Este coeficiente é calculado pela equação: 


$$
R^{2}=\left[\frac{\left(\sum_{i=1}^{n}\left(y_{i}^{\text {obs }}-y_{i}^{\text {med.obs }}\right)\left(y_{i}^{\text {sim }}-y_{i}^{\text {med.sim }}\right)\right)^{2}}{\sum_{i=1}^{n}\left(y_{i}^{\text {obs }}-y^{\text {med.obs }}\right)^{2} \sum_{i=1}^{n}\left(y_{i}^{\text {sim }}-y^{\text {med.sim }}\right)^{2}}\right]
$$

O índice de Nash-Sutcliffe (NASH E SUTCLIFFE, 1970) é calculada por:

$$
\text { ENS }=1-\left[\frac{\sum_{i=1}^{n}\left(y_{i}^{o b s}-y_{i}^{\operatorname{sim}}\right)^{2}}{\sum_{i=1}^{n}\left(y_{i}^{o b s}-y^{\text {med.obs }}\right)^{2}}\right]
$$

Em que:

E= Eficiência de Nash-Sutcliffe

$\mathrm{y}_{\mathrm{i}}{ }^{\text {obs }}$ é a vazão observada;

$\mathrm{yi}^{\text {sim }}$ é a vazão simulada;

$\mathrm{y}^{\text {med.obs }}$ é a média da vazão observada e;

$\mathrm{y}^{\text {med.sim }}$ é a média da vazão simulada.

O coeficiente de Nash-Sutcliffe pode variar no intervalo de - $\infty$ até 1 , sendo que quanto mais próximo de 1, melhor é avaliada a calibração.

O percentual de tendências (PBIAS) mede a tendência média dos dados simulados para ser maior ou menor do que os observados. O valor ótimo equivale a zero, e valores próximos a zero indicam melhores simulações. Para este índice, valores negativos apontam para subestimação do modelo e positivos, superestimação. Este índice é calculado pela equação:

$$
\text { PBIAS }=\left\lfloor\frac{\sum_{i=1}^{n}\left(Q_{o b s}-Q_{s}\right)}{\sum_{i=1}^{n} Q_{o b s}}\right\rfloor
$$

Em que:

Qobs é a vazão observada;

$\mathrm{Q}_{\mathrm{s}}$ é a vazão simulada pelo modelo; 
Para facilitar a avaliação das simulações quanto a precisão dos dados simulados em comparação com os observados, recorreu-se ao estudo de Moriasi et al. (2007), que propõe uma classificação qualitativa para os índices estatísticos.

O procedimento de calibração da vazão foi feito de forma automática durante $\mathrm{o}$ período 01/01/2004 a 31/12/2010, utilizando o algoritmo SUFI-2 disponível no SWATCUP2012. A calibração foi realizada usando os parâmetros mais sensíveis, identificados na análise de sensibilidade.

Com o modelo calibrado para as condições locais, deu-se início ao procedimento de verificação, a fim de avaliar a resposta do modelo para outro período. Assim, utilizou-se o período de 01/01/2011 a 31/12/2014 para verificação da modelagem.

O Apêndice-A apresenta de forma esquemática, todos os procedimentos metodológicos. 


\section{RESULTADOS E DISCUSSÃO}

Este capítulo é dedicado a apresentação e discussão dos resultados obtidos ao longo do desenvolvimento desta pesquisa. A seção 5.1 traz os resultados obtidos na caracterização da área de estudo, que abrangem informações sobre o relevo, uso e ocupação do solo, pedologia, clima e informações hidrológicas da microbacia. Na seção 5.2 são apresentados e discutidos os resultados da aplicação do modelo SWAT, que envolvem as etapas de simulação, calibração, verificação e avaliação do desempenho do modelo em predizer os dados de vazão. A seção 5.3 finaliza este capítulo com os resultados da análise comparativa entre os cenários de 2005 e 2014, quanto as estimativas de escorrimento superficial, produção de sedimentos e a comparação das taxas de produção de sedimento com outros estudos.

\subsection{Caracterização da Área de Estudo}

\subsubsection{Relevo}

A Figura 13 apresenta o mapa hipsométrico da microbacia do córrego Cana do Reino adotada nesta pesquisa como local de estudo. 


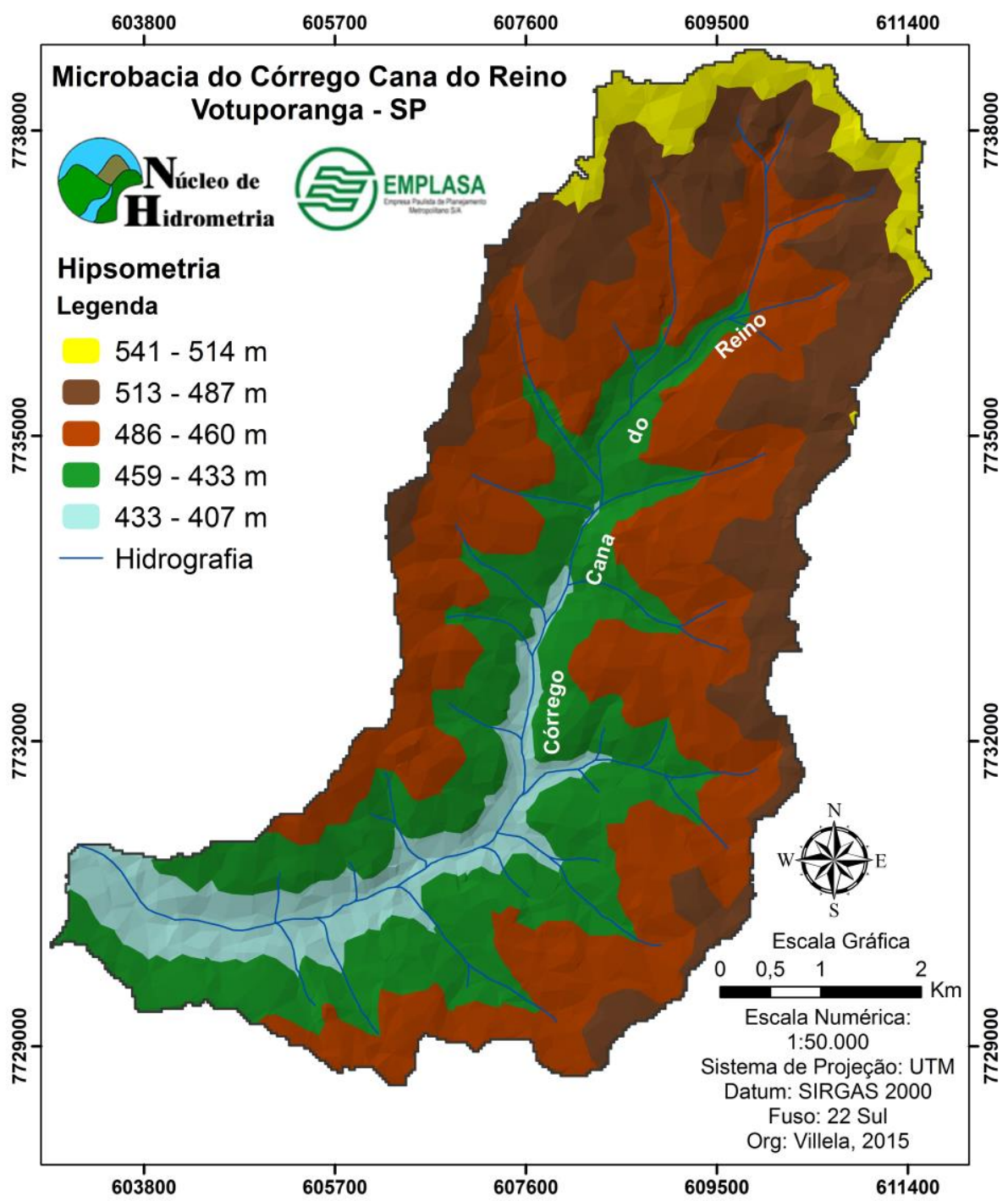

Figura 13 Mapa hipsométrico da microbacia do córrego Cana do Reino, Votuporanga - SP.

Nota-se que a altitude máxima da microbacia é de 541 metros e a mínima de 407 metros, sendo verificado uma amplitude altimétrica de 134 metros. Constatou-se que a altitude média da microbacia corresponde a cota de 474 metros.

Na Figura 14 pode-se observar o perfil topográfico longitudinal da microbacia. 


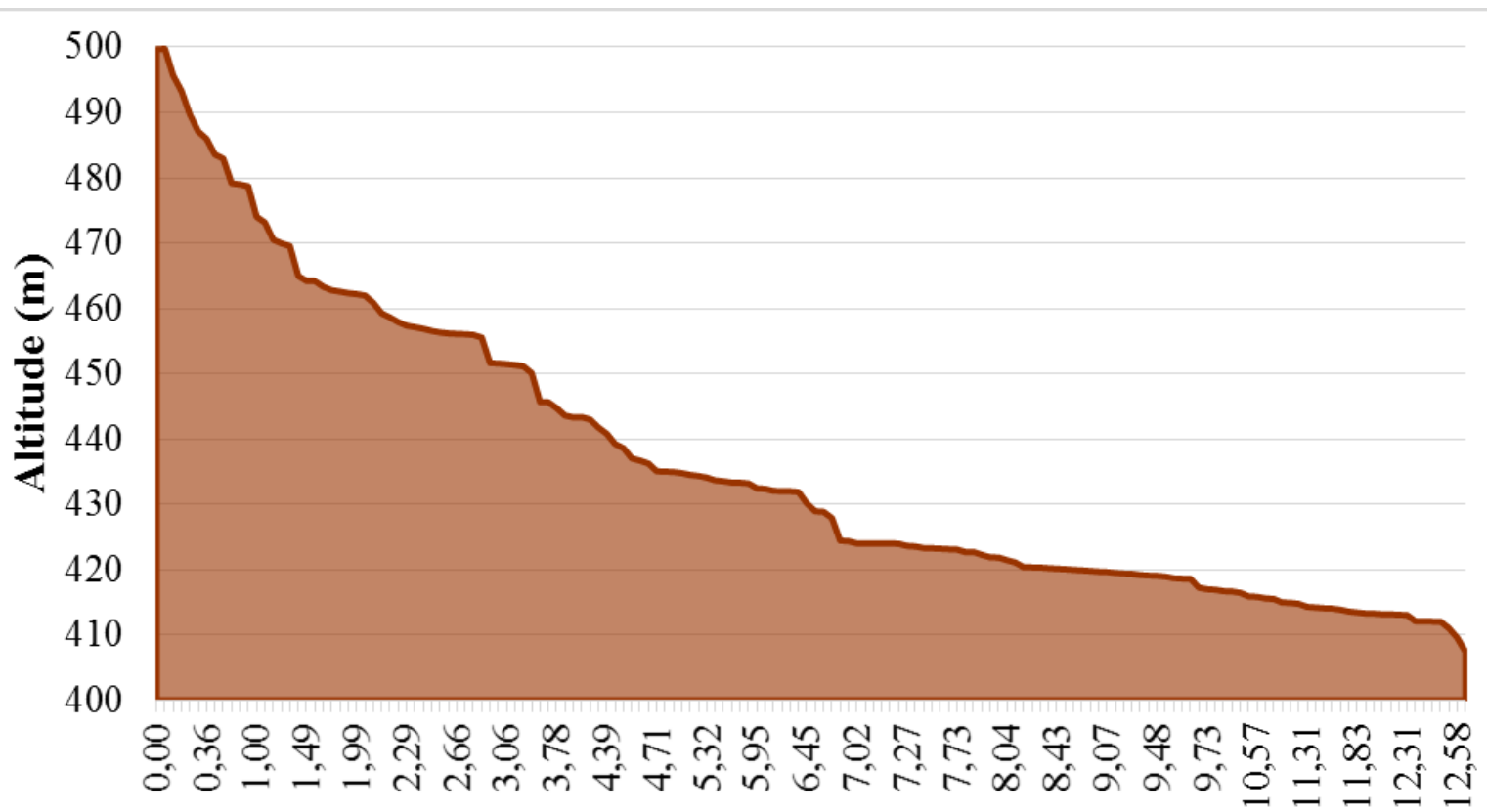

Distância (Km)

Nota-se que a maior variação altimétrica encontra-se nos primeiros 1,5 km de extensão (490 a 465 m), reduzindo em uma razão de 7 metros por quilômetro, até alcançar o trecho médio do canal. A partir desse ponto, ocorre o aplanamento do relevo, onde a diferença de nível de 20 metros é distribuída ao longo dos últimos 5,3 km de extensão.

\subsubsection{Clinografia}

O mapa clinográfico da microbacia é apresentado na Figura 15, onde os valores das declividades foram divididos em 7 classes deferentes. 


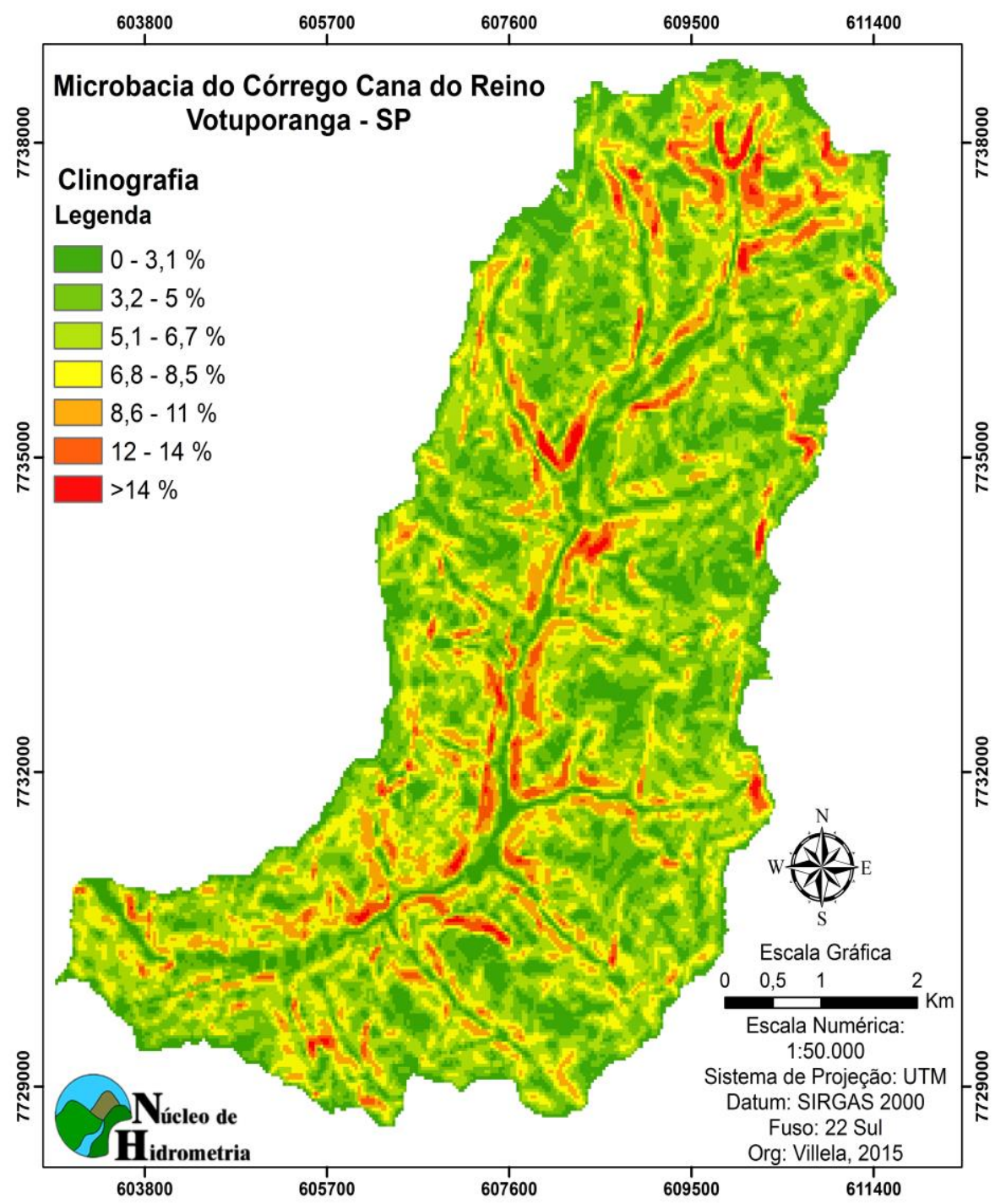

Figura 15 Classes de declividade da microbacia do córrego Cana do Reino, Votuporanga - SP.

Conforme o mapa apresentado na Figura 15 pôde-se constatar que em aproximadamente $41,9 \%$ da área da microbacia (1769,8 ha), a declividade varia de 0 a $5 \%$. A área com declividade entre 5 a $8 \%$ corresponde a de 1714,6 ha, 40,6\% da microbacia. Nota-se que em mais de $80 \%$ da área da microbacia a declividade varia de 0 a $8 \%$, o que classifica o relevo como sendo plano $(0-3 \%)$ e suave ondulado $(3,1-8 \%)$ (EMBRAPA, 1979). As declividades superiores a $8 \%$ foram verificadas em apenas $17,3 \%$ da área total, sendo localizadas em maior proporção na região de cabeceira e ao redor da calha do rio. 


\subsubsection{Pedologia}

Os solos presentes na área de estudo, de acordo com o levantamento realizado na microbacia descrito na seção 4.2.2, são: Latossolo Vermelho Eutrófico textura média/arenosa (LVpe ar/md); Latossolo Vermelho Distrófico textura média (LVd md); Argissolo Vermelho Eutrófico textura arenosa/média (PVe ar/md) e Argissolo Vermelho Eutrófico textura arenosa/argilosa (PVe ar/arg).

A Figura 16 apresenta o mapeamento das classes de solos definidas pelo levantamento pedológico.

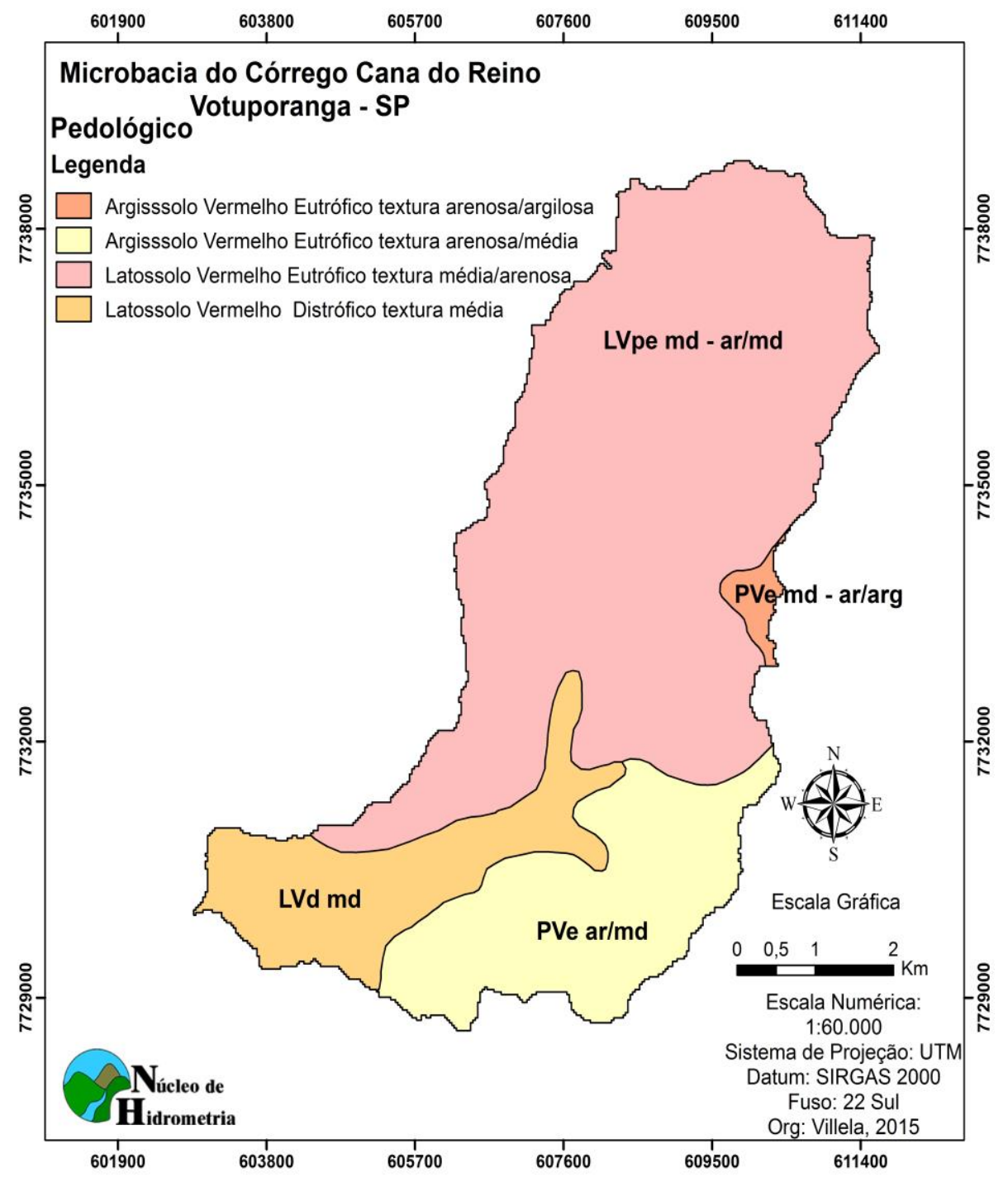

Figura 16. Mapeamento das classes de solos definidas pelo levantamento pedológico. 
Observa-se o predomínio dos Latossolo Vermelho Eutrófico textura média/arenosa (LVpe ar/md) que ocupa as porções alta e média da microbacia. Verifica-se que este tipo de solo corresponde a aproximadamente 2751 ha, cerca de $65,2 \%$ da área total da microbacia. Já o Latossolo Vermelho Distrófico textura média ( $\mathrm{LVd}$ md) estão presentes em aproximadamente $14,4 \%$ da microbacia, situado na porção mais baixa da microbacia. Nesta região também encontra-se Argissolo Vermelho Eutrófico textura arenosa/média (PVe ar/md) que perfaz aproximadamente $19,2 \%$ da microbacia. Por fim, com menor representatividade está o Argissolo Vermelho Eutrófico textura arenosa/argilosa (PVe ar/arg), ocupando cerca de $1,2 \%$ da microbacia.

De acordo com IAC (1999), os Latossolos Vermelho Eutróficos apresentam características como: solos profundos, friáveis ou muito friáveis, com coloração brumo avermelhada no horizonte B, textura média e estrutura fracamente desenvolvida. Segundo IPT (2008), a grande variação textural, com teores de argila de 16 a $85 \%$ no horizonte B, confere aos solos dessa classe apreciável disparidade quanto à infiltração e capacidade de retenção de água e nutrientes.

Em relação aos Argissolos Vermelho Eutrófico, segundo IPT (2008), compreendem solos minerais não hidromórficos, com horizonte B textural. São solos muito profundos e apresentam baixo gradiente textural entre os horizontes A e B e estrutura fracamente desenvolvida. Estes solos estão muito vulneráveis à erosão em áreas de alta declividade.

\subsubsection{Uso e Ocupação do Solo}

Neste item são apresentados os mapas de uso e ocupação dos cenários de 2005 e 2014. O cenário de 2005 retrata o período que antecede a expansão do cultivo da cana-de-açúcar, cujo uso é predominantemente de pastagem. Já o cenário de 2014 representa a fase de expansão do cultivo de cana-de-açúcar na microbacia, o qual se deu majoritariamente sobre áreas de pastagem. 
A Figura 17 apresenta os tipos de usos de solo presentes na microbacia para o cenário de 2005 .

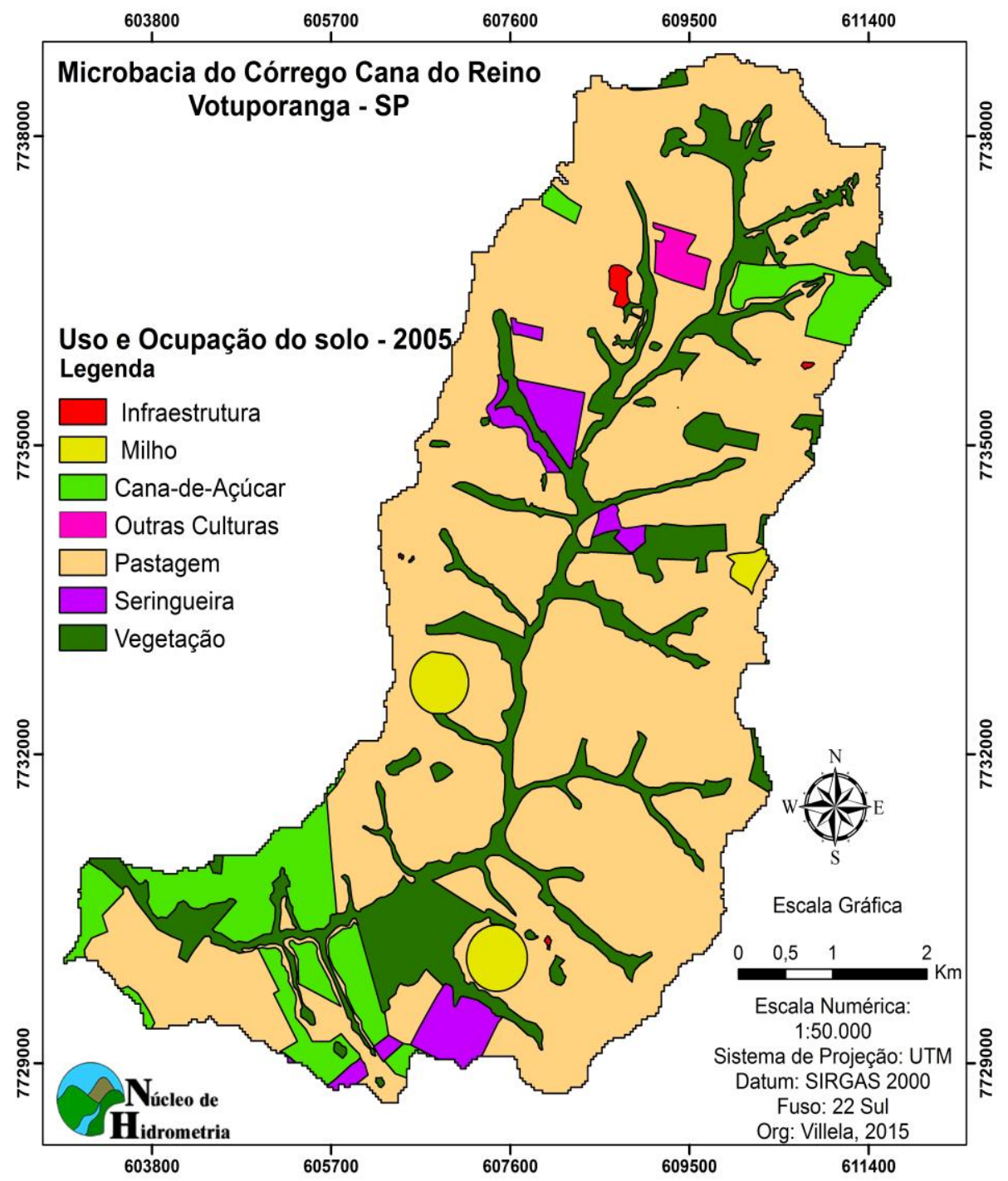

Figura 17. Tipos de usos de solo presentes na microbacia no cenário de 2005

Observa-se na Figura 17 que a microbacia é ocupada por grandes áreas de pastagem, onde verifica-se a presença em aproximadamente $71,2 \%$ da microbacia. $\mathrm{O}$ segundo uso com maior porcentagem de área $(15,9 \%)$, corresponde a vegetação sendo representadas por áreas de preservação permanente e reserva legal com a presença de fragmentos de cerrado. $\mathrm{O}$ cultivo de cana-de-açúcar ocupa cerca de $7,7 \%$ da microbacia e está localizada em grande parte na região sul. Já o cultivo da seringueira está presente em aproximadamente $2,8 \%$ da 
microbacia, sendo observada na porção central e sul da área de estudo. Com menor representatividade estão: milho, outras culturas e infraestrutura, que ocupam respectivamente cerca de $1,8,0,5$ e $0,1 \%$ da microbacia.

A Tabela 3 apresenta o percentual e a área de cada classe de uso e ocupação presente na microbacia no cenário de 2005.

Tabela 3. Percentual e a área de cada classe de uso presente na microbacia no cenário de 2005.

\begin{tabular}{ccc}
\hline Classe de Uso e Ocupação & Área (ha) & Área $(\%)$ \\
\hline Pastagem & 3000 & 71,2 \\
\hline Vegetação & 667 & 15,9 \\
\hline Cana-de-Açúcar & 323 & 7,7 \\
\hline Seringueira & 119 & 2,8 \\
\hline Milho & 73 & 1,8 \\
\hline Outras Culturas & 26 & 0,5 \\
\hline Infraestrutura & 8 & 0,1 \\
\hline
\end{tabular}

A Figura 18 apresenta a evolução do cultivo de cana-de-açúcar na microbacia registrada no cenário de 2014 e no município de Votuporanga.

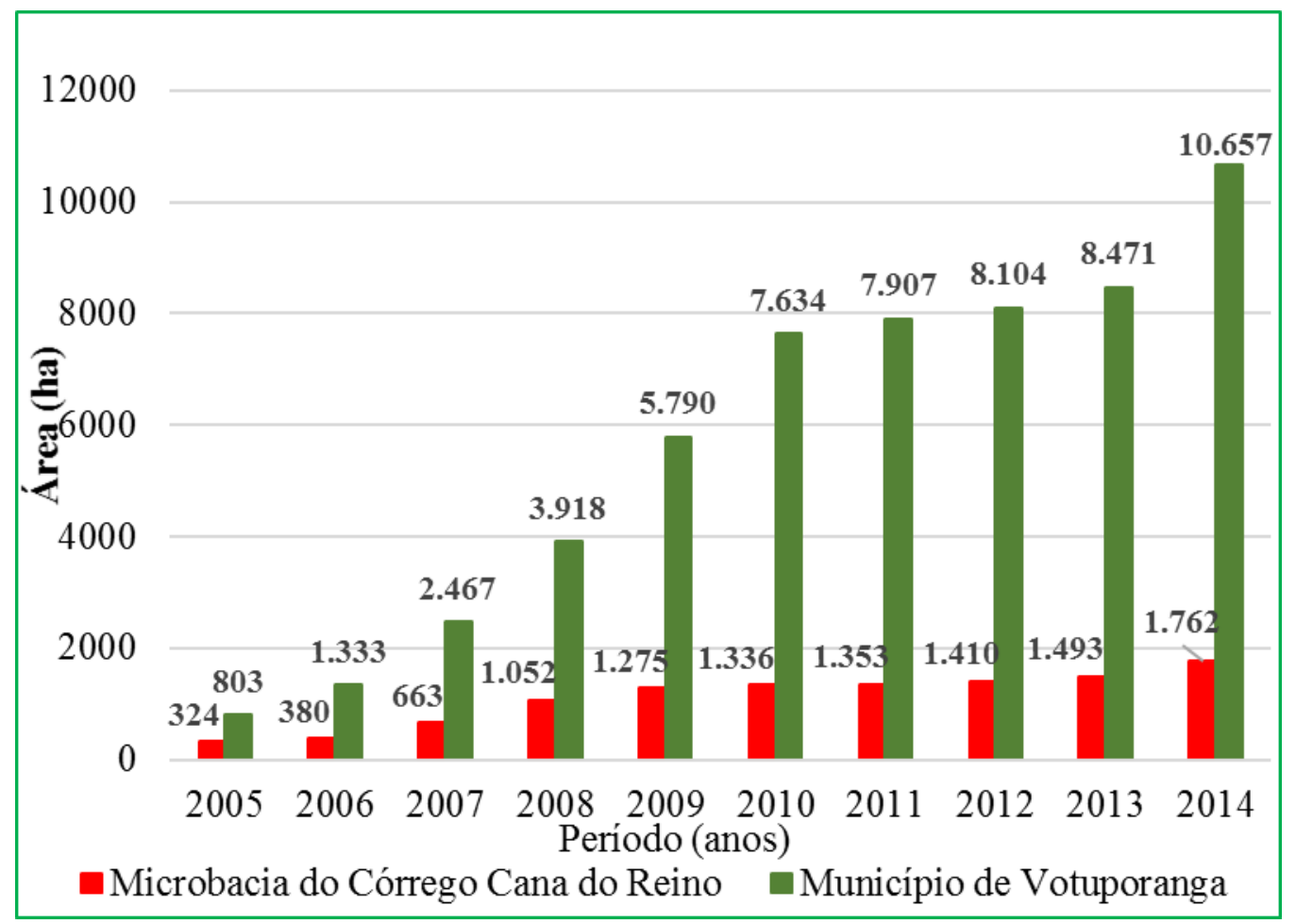

Figura 18. Evolução do cultivo de cana-de-açúcar na microbacia no cenário de 2014 e no município de Votuporanga. 
Nota-se que a expansão do cultivo ocorreu de forma expressiva no município, registrando um acréscimo de 803 ha em 2004 para 10.657 ha em 2014. Na microbacia registrou-se um aumento 443\%, sendo verificado a presença de 324 ha em 2005 e no ano de 2014, 1.762 ha. Observa-se que o ápice da expansão ocorreu no período de 2005 a 2010, no qual constatou um acréscimo médio de 202 ha para a microbacia e 1.366 ha para o município. A expansão na microbacia pode ser vista de forma espacializada na Figura 19.

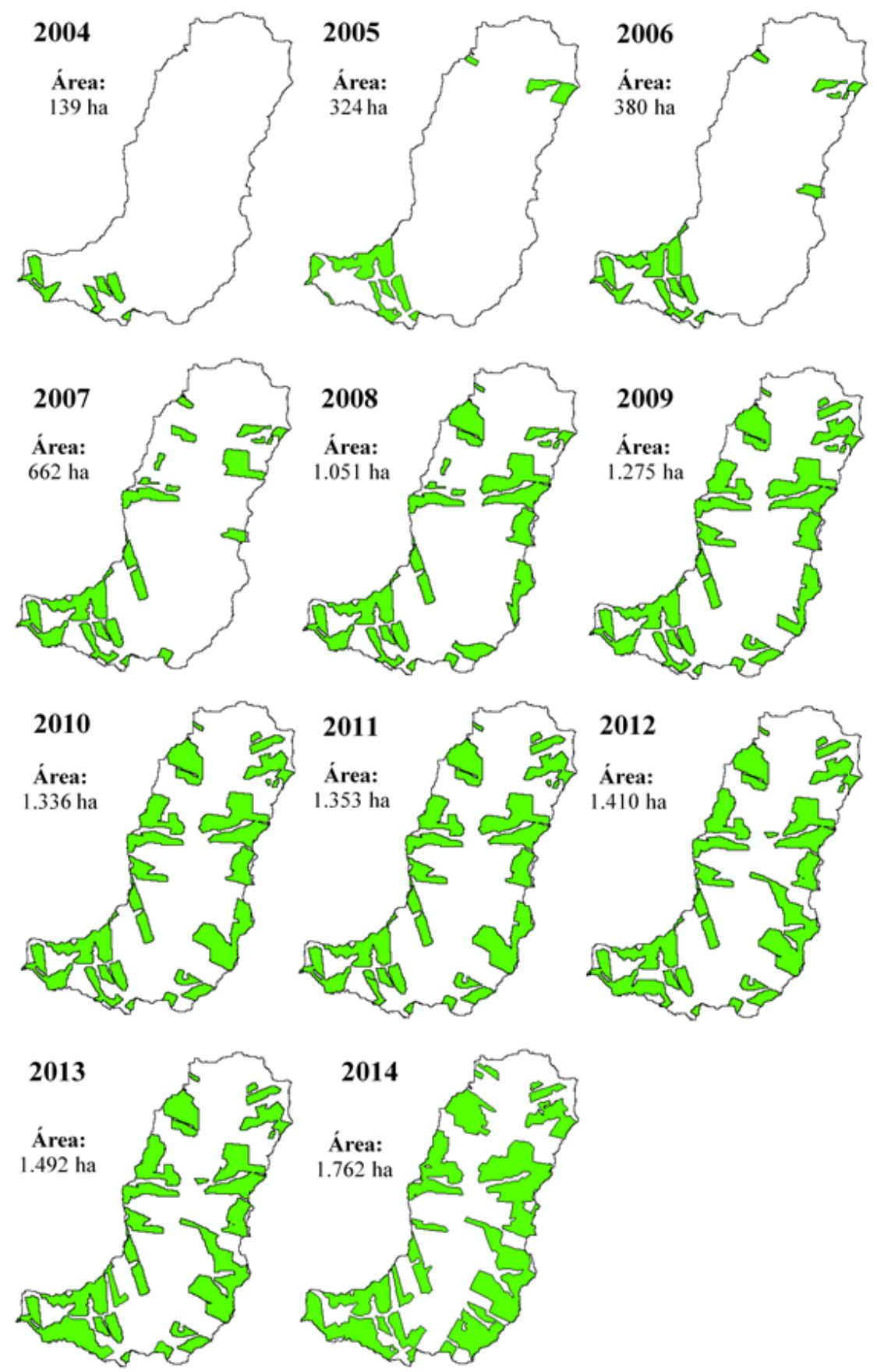

Figura 19. Expansão do cultivo de cana-de açúcar (2004- 2014) na microbacia. 
A Figura 20 apresenta o mapa de uso e ocupação para o cenário de 2014 no qual verifica-se além do aumento no cultivo de cana-de-açúcar, o acréscimo de áreas do plantio de seringueira.

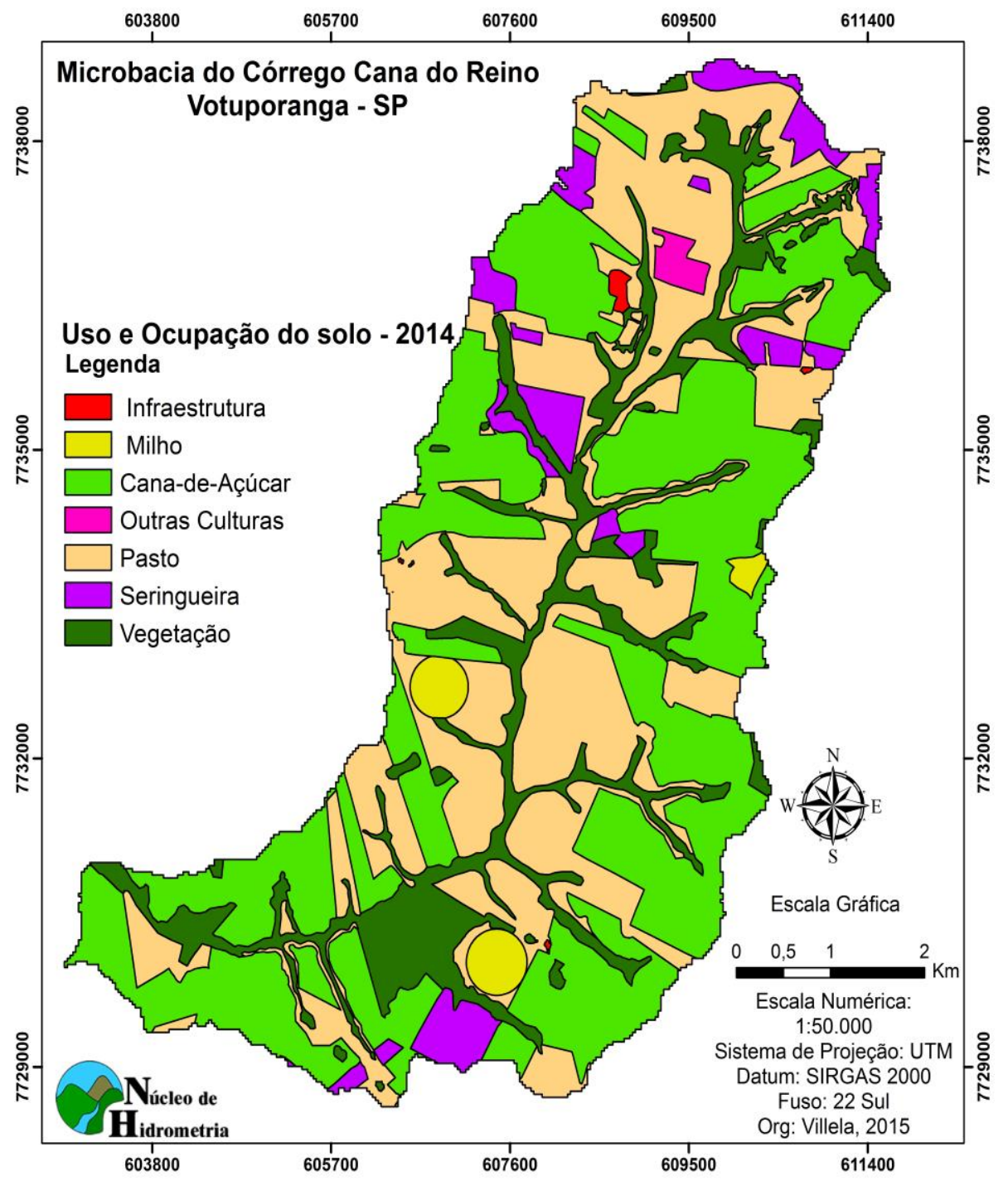

Figura 20. Mapa de uso e ocupação para o cenário de 2014.

Ao analisar a Figura 20 constata-se que o uso predominante na microbacia é do cultivo de cana-de-açúcar, que perfaz uma área de $41,7 \%$ da área total. O segundo uso predominante é o de pastagem, que corresponde aproximadamente a 35,6\%, seguido pelas áreas de vegetação (com cerca de 14,8\%), e o cultivo da seringueira 5,6\% da microbacia. 
Os usos denominados como milho, outras culturas e infraestrutura ocupam respectivamente cerca de $1,7,0,5$ e $0,1 \%$.

A Tabela 4 apresenta as quantidades de área de cada uso para os dois cenários, para demonstrar uma visão geral das mudanças de uso e ocupação que ocorreram entre os cenários de 2005 e 2014.

Tabela 4. Mudanças de uso e ocupação entre os cenários de 2005 e 2014.

\begin{tabular}{ccccc}
\hline \multirow{2}{*}{ Classe de Uso e Ocupação } & \multicolumn{2}{c}{ Cenário 2005 } & \multicolumn{2}{c}{ Cenário 2014 } \\
\cline { 2 - 5 } & $\begin{array}{c}\text { Área } \\
\text { (ha) }\end{array}$ & Área (\%) & $\begin{array}{c}\text { Área } \\
\text { (ha) }\end{array}$ & Área (\%) \\
\hline Pastagem & 3000 & 71,1 & 1486 & 35,6 \\
\hline Vegetação & 667 & 15,9 & 625 & 14,6 \\
\hline Cana-de-açúcar & 323 & 7,7 & 1762 & 41,7 \\
\hline Seringueira & 119 & 2,8 & 239 & 5,6 \\
\hline Milho & 73 & 1,8 & 79 & 1,9 \\
\hline Outras culturas & 26 & 0,6 & 23 & 0,5 \\
\hline Infraestrutura & 8 & 0,1 & 8 & 0,1 \\
\hline Área total da Microbacia & \multicolumn{5}{c}{4.216 ha } \\
\hline
\end{tabular}

Analisando a Tabela 4 observa-se que do cenário de 2005 para o de 2014 houve uma significativa redução das áreas de pastagem, resultando em um decréscimo de aproximadamente $35,5 \%$. Por outro lado, verifica-se um aumento de cerca de $34 \%$ das áreas com cultivo de cana-de-açúcar na microbacia, que ocorreu principalmente sobre as áreas de pastagem. Constata-se também, que o aumento registrado no cultivo de seringueira de $2,8 \%$ ocorreu em áreas de pastagem e de vegetação.

\subsubsection{Clima}

De acordo com a classificação de Köppen, o clima predominante na microbacia é o tropical com verão chuvoso e inverno seco (Aw), com temperatura média anual de $22^{\circ}$ (IAC, 1999). A pluviosidade média anual é de $1.344 \mathrm{~mm}$, com maior incidência das chuvas no período de outubro a março e menor de abril a setembro. 


\subsection{Aplicação do modelo SWAT}

Para realizar a modelagem hidrológica a microbacia do córrego Cana do Reino foi dividida em 39 sub-bacias, conforme Figura 21. Nesta divisão, procurou-se manter um certo grau de proporcionalidade entre as áreas das sub-bacias, além de selecionar o exutório da subbacia 35 na mesma localização onde se encontra o posto de vazão.

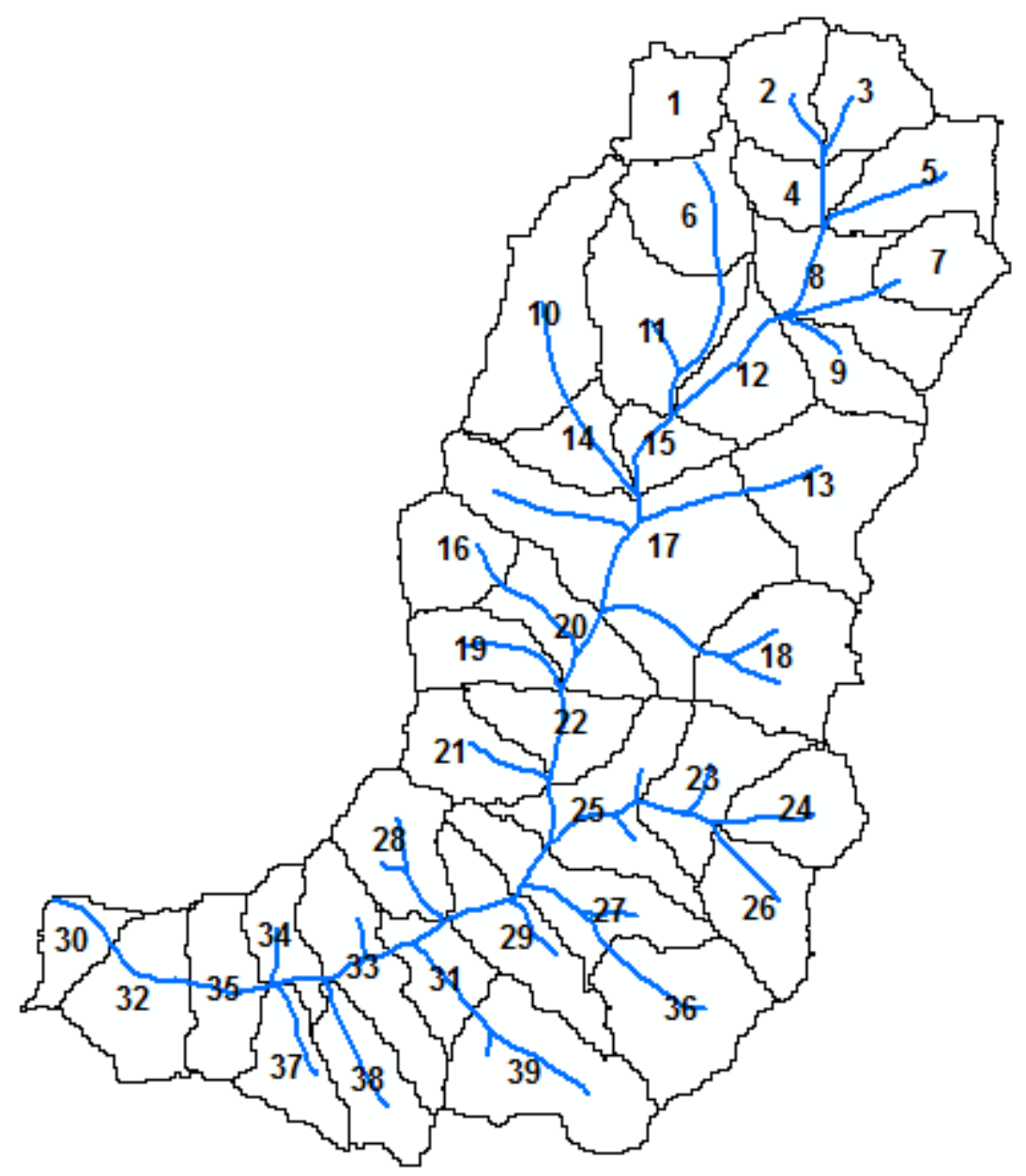

Figura 21. Divisão das sub-bacias na microbacia do córrego Cana do Reino, Votuporanga - SP.

Para a simulação referente ao cenário de 2005 foram criadas 297 HRU, que corresponde a 297 combinações diferentes entre uso e ocupação do solo, tipo de solo e classes de declividade. No cenário de 2014 o número de HRU geradas foi de 365, demostrando ser mais heterogêneo em relação a disposição das classes de uso do solo. 
Para uma avaliação inicial dos resultados da modelagem realizada nesse estudo, comparou-se os valores de vazão simulados para o ano de 2014, com os dados observados do posto fluviométrico. Essa avaliação teve como objetivos verificar a qualidade da simulação, medindo o grau de correspondência entre os valores simulados e observados, e a partir desta, direcioná-la ou não para os procedimentos de calibração. Sendo assim, além da comparação gráfica realizada entre os valores simulados e observados (Figura 22), aplicou-se também os seguintes testes estatísticos: coeficiente de determinação $\left(\mathrm{R}^{2}\right)$, índice de Nash-Sutcliffe (NSE) e o percentual de tendências (PBIAS).

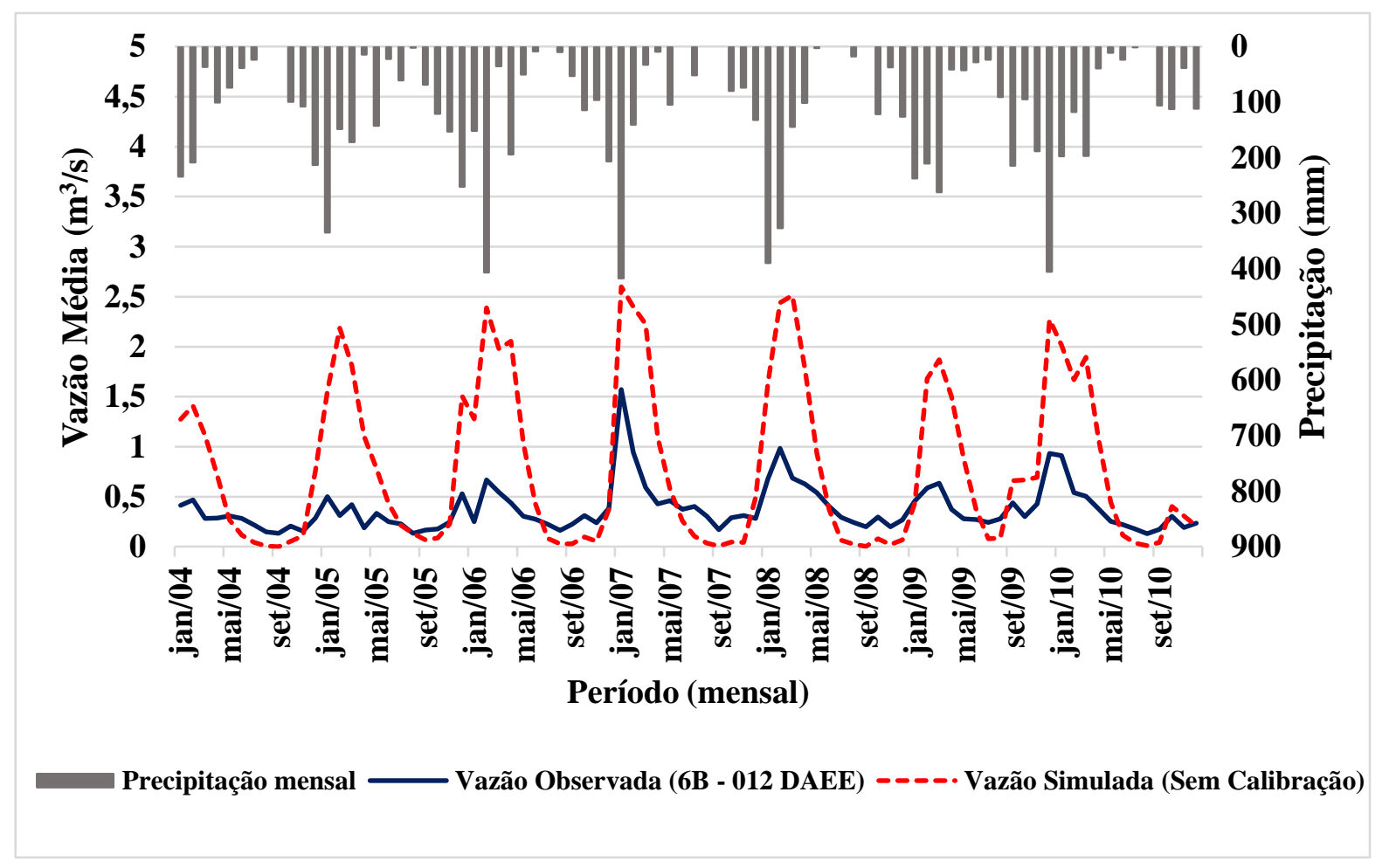

Figura 22 - Hietograma e hidrogramas observado e simulado (sem calibração) mensal para o período de 2004 a 2010.

Por meio da análise gráfica, é possível notar que os dados simulados não conseguem representar de forma aceitável a vazão observada nesse período. Observa-se que os valores simulados respondem de forma subestimada nos períodos de estiagem e superestimados nos períodos chuvosos. No entanto, verifica-se que embora não haja uma boa aderência entre os dados simulados e observados, ainda assim, os valores simulados conseguem reconhecer, 
mesmo que de forma superestimada, os picos de vazões dos dados observados. De certa forma, este comportamento representa um bom indicativo, pois dá indícios de que a simulação pode ser melhorada se submetida aos procedimentos de calibração.

De forma geral, a simulação apresentou desempenho insatisfatório perante aos testes estatísticos utilizados para avaliar a eficiência da modelagem. Para o coeficiente de determinação $\mathrm{R}^{2}$ (Figura 23), obteve-se um valor igual a 0,6405, o qual indica um desempenho insatisfatório da simulação.

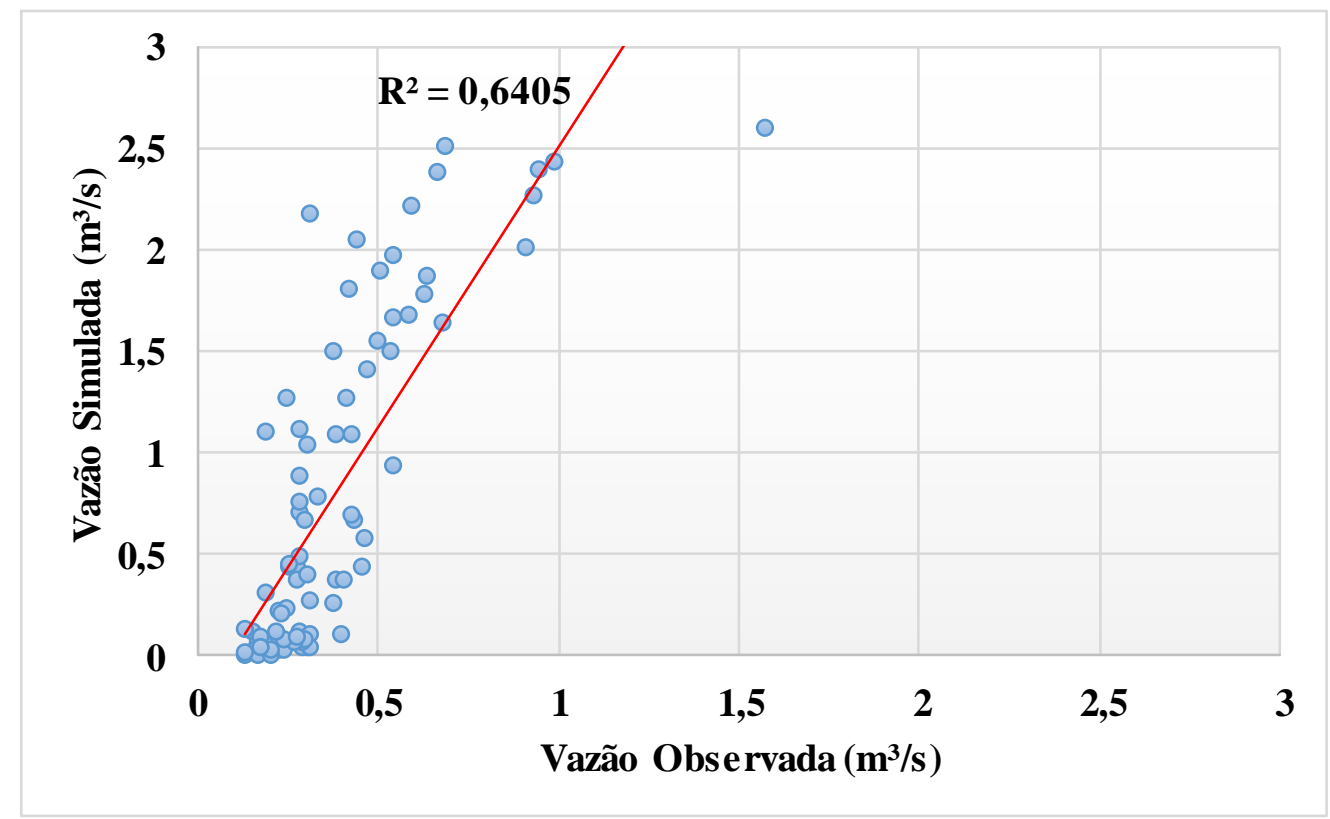

Figura 23. Diagrama de dispersão das vazões médias mensais observadas e simuladas (sem calibração) para o período de 2004 a 2010 na microbacia.

Quanto aos valores de Nash-Sutcliffe (NSE) e do percentual de tendências (PBIAS), a simulação apresentou os respectivos valores -2,17 e -94, 6. De acordo Moriasi et al. (2007), os valores obtidos nesses testes, indicam um comportamento insatisfatório, pois o valor mínimo para enquadrar-se como sendo satisfatório para o NSE é de 0,5 e para o PBIAS entre $\pm 15<$ PBIAS < $₫ 25$. O valor do percentual de tendências (PBIAS) indica que a simulação está superestimada em 94,6\% em relação aos dados observados.

Dessa forma, verificou-se a necessidade de submeter esta modelagem aos procedimentos de calibração, a fim de alcançar valores satisfatórios entre as vazões simulada 
e os valores observados. Antes de iniciar o processo de calibração, realizou-se uma análise de sensibilidade para identificar os parâmetros que exerciam maior influência na modelagem para vazão.

\subsubsection{Análise de Sensibilidade}

O primeiro passo desta etapa foi selecionar os parâmetros que iriam participar da análise de sensibilidade. A escolha dos parâmetros baseou-se em Arnold et al. (2012), que elencaram os parâmetros mais sensíveis, após uma meta-análise de 64 estudos realizados no mundo com o SWAT. Alguns trabalhos nacionais também foram consultados, tais como: Aragão et al. (2013), Lelis et al. (2012) e Adriolo et al. (2008).

Com base nesses estudos, foram selecionados 11 parâmetros para o ajuste da modelagem. A análise de sensibilidade tem por finalidade identificar qual a influência dos parâmetros de entrada sobre a simulação de vazão.

Deste modo, utilizando o software SWATCUP realizou-se as análises de sensibilidade global e individual para este estudo, durante o período de 01/01/2004 a 31/12/2014. O resultado dessa análise foi obtido através de 150 interações, realizadas entre os 11 parâmetros, utilizando os seguintes intervalos (Tabela 5).

Tabela 5. Resultado das análises de sensibilidade global e individual.

\begin{tabular}{|c|c|c|c|c|c|}
\hline Parâmetro & Descrição & $\begin{array}{l}\text { Valores } \\
\text { Iniciais }\end{array}$ & $\begin{array}{c}\text { Tipo de } \\
\text { Alteração } \\
\text { R(X) V(=) }\end{array}$ & \multicolumn{2}{|c|}{$\begin{array}{l}\text { Intervalo } \\
\text { Máx } \\
\text { Mín }\end{array}$} \\
\hline $\begin{array}{c}\mathbf{R}-\mathbf{S O L} \mathbf{K} . \mathbf{s o l} \\
(\mathbf{m m} / \mathbf{h r})\end{array}$ & $\begin{array}{c}\text { Condutividade hidráulica } \\
\text { saturada do solo }\end{array}$ & $\begin{array}{l}125 \\
\text { (méd) }\end{array}$ & $\mathrm{X}$ & $-0,1$ & $-0,25$ \\
\hline $\begin{array}{c}\text { V - ALPHA_BF } \\
\text { (Dias) }\end{array}$ & $\begin{array}{l}\text { Constante de recessão do } \\
\text { fluxo de base }\end{array}$ & 0,048 & $=$ & 0 & 0,3 \\
\hline $\begin{array}{c}\text { V - CH_N2 } \\
\text { (Adim) }\end{array}$ & $\begin{array}{l}\text { Limiar da profundidade } \\
\text { da água no aquífero } \\
\text { superficial necessária para } \\
\text { o fluxo de retorno ocorrer }\end{array}$ & 0,014 & $=$ & 0,05 & 0,25 \\
\hline $\begin{array}{c}\text { V - GWQMN } \\
(\mathbf{m m})\end{array}$ & $\begin{array}{l}\text { Coeficiente "revap" de } \\
\text { água subterrânea }\end{array}$ & 0 & $=$ & 0,4 & 0,8 \\
\hline
\end{tabular}




\begin{tabular}{|c|c|c|c|c|c|}
\hline $\begin{array}{c}\text { V - CH_K2 } \\
(\mathbf{m m} / \mathbf{h r})\end{array}$ & $\begin{array}{l}\text { Valor " } n \text { " de Manning } \\
\text { para o canal principal }\end{array}$ & 0 & $=$ & 0 & 10 \\
\hline $\begin{array}{c}\text { V - ALPHA_BNK } \\
\text { (Dias) }\end{array}$ & $\begin{array}{c}\text { Fator alfa de escoamento } \\
\text { de base para } \\
\text { armazenamento de } \\
\text { aquífero }\end{array}$ & 0 & $=$ & 0,25 & 0,5 \\
\hline $\begin{array}{l}\text { V - ESCO } \\
\text { (Adim) }\end{array}$ & $\begin{array}{l}\text { Fator de compensação de } \\
\text { evaporação do solo }\end{array}$ & 0 & $=$ & 0,2 & 0,4 \\
\hline $\begin{array}{l}\text { R - CN2 } \\
\text { (Adim) }\end{array}$ & $\begin{array}{l}\text { Curva número na } \\
\text { condição }\end{array}$ & $\begin{array}{c}62 \\
\text { (méd) }\end{array}$ & $X$ & $-0,45$ & $-0,25$ \\
\hline
\end{tabular}

\begin{tabular}{cccccc}
\hline $\begin{array}{c}\text { V - GW_DELAY } \\
\text { (Dias) }\end{array}$ & $\begin{array}{c}\text { Tempo de retardo da água } \\
\text { subterrânea }\end{array}$ & 31 & $=$ & 80 & 350 \\
\hline $\begin{array}{c}\text { V - GW_REVAP } \\
\text { (Adim) }\end{array}$ & $\begin{array}{c}\text { Coeficiente "revap" de } \\
\text { água subterrânea }\end{array}$ & 0,02 & $=$ & 0,05 & 0,17 \\
\hline R - SOL_AWC & $\begin{array}{c}\text { Capacidade de água } \\
\text { disponível no solo }\end{array}$ & $\begin{array}{c}0,9 \\
\text { (méd) }\end{array}$ & $\mathrm{X}$ & 0,2 & 0,5 \\
\hline
\end{tabular}

$\mathbf{R}(\mathbf{X})$ multiplicar; $\mathbf{V ( = )}$ igualar e méd. (alguns parâmetros possuem valores que variam entre tipos de solo e camadas, portanto, atribui-se o valor médio).

Os parâmetros podem ser ajustados de três formas diferentes, variando de acordo com cada parâmetro. Pelo método da multiplicação (R), em caso de valores positivos, há um acréscimo em termos percentuais, sendo negativos, efetua-se decréscimo. No método de igualar (V), o valor obtido pela análise de sensibilidade é substituído integralmente. Por fim, o método da soma (A), nesse método o valor obtido pela análise de sensibilidade é somado ao valor antigo do parâmetro.

A Figura 24 apresenta os resultados da análise de sensibilidade global dos parâmetros, com os respectivos valores $t$-stat e o valor de $\mathrm{P}$ (P-Value). De acordo com Abbaspour et al. (2012), o $t$-stat representa o nível de sensibilidade, sendo que quanto maior o valor de $t$-stat, mais sensível é o parâmetro para a modelagem. O $(P$-Value $)$ está relacionado a significância da sensibilidade dos parâmetros, de modo que quanto menor índice, mais significante é o parâmetro para a simulação. 
Com os resultados da análise pôde-se verificar que os parâmetros mais sensíveis foram: SOL_AWC, CN2, GWQMN, SOL_K, ALPHA_BNK, ESCO, CH_K2, GW_REVAP, ALPHA_BF, GW_DELAY e CH_N2. Em ordem decrescente os parâmetros SOL_AWC, CN2, GWQMN, SOL_K apresentaram maior nível de sensibilidade e significância para esta modelagem.

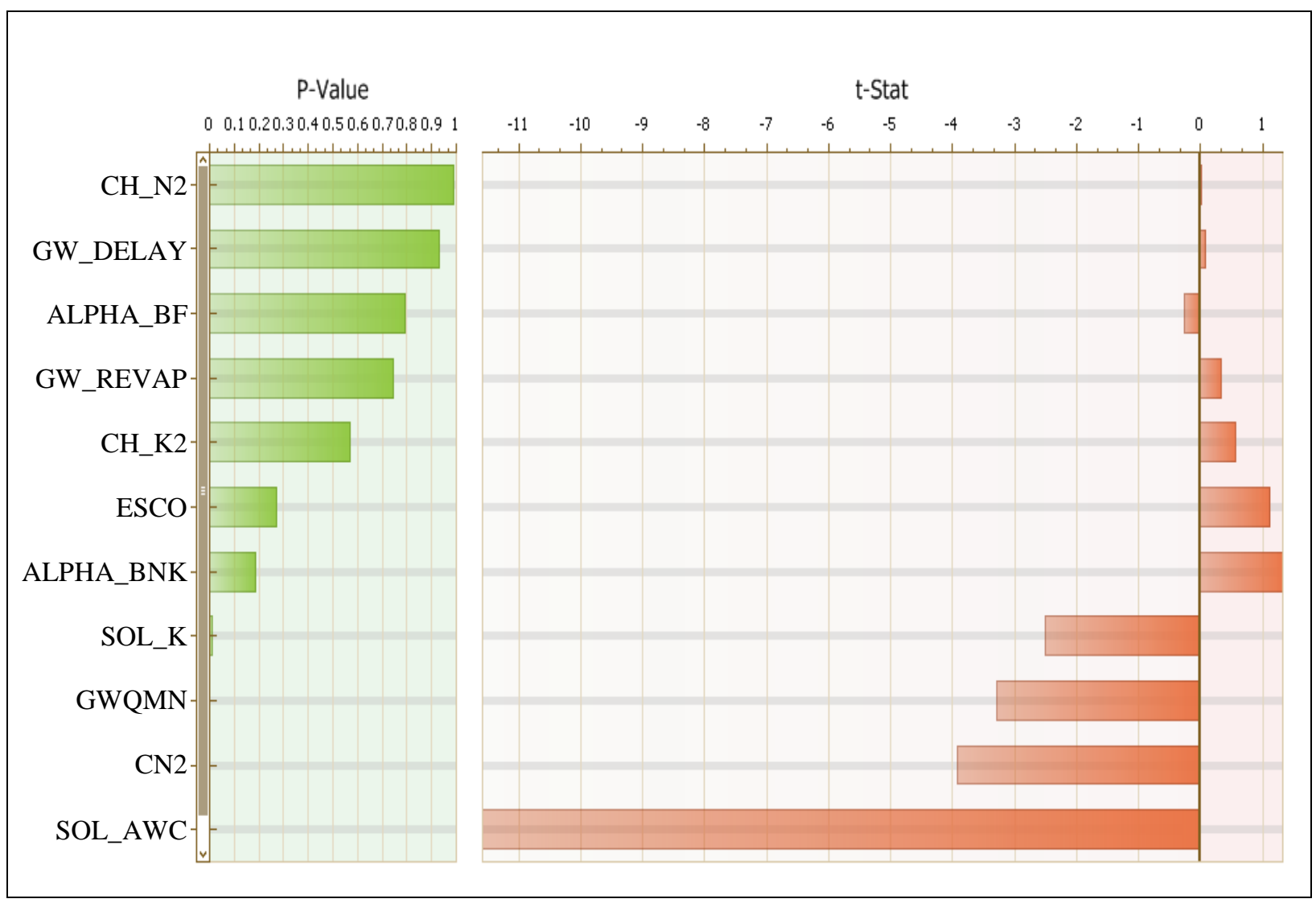

Figura 24. Resultado análise de sensibilidade dos parâmetros do SWAT para a microbacia.

Na Figura 24 é possível notar uma grande diferença entre os parâmetros mais sensíveis (SOL_AWC, CN2, GWQMN, SOL_K) e os demais. A mesma análise pode ser feita conforme os valores absolutos descritos na Tabela 6. 
Tabela 6. Valores de $t$-stat e $\boldsymbol{P}$-Value obtidos pela análise de sensibilidade dos parâmetros.

\begin{tabular}{ccc}
\hline Parâmetro & t-Stat & $\begin{array}{c}\text { P- } \\
\text { Value }\end{array}$ \\
\hline CH_N2 & 0,01 & 0,99 \\
\hline GW_DELAY & 0,09 & 0,93 \\
\hline ALPHA_BF & $-0,26$ & 0,79 \\
\hline GW_REVAP & 0,32 & 0,75 \\
\hline CH_K2 & 0,57 & 0,57 \\
\hline ESCO & 1,10 & 0,27 \\
\hline ALPHA_BNK & 1,33 & 0,19 \\
\hline SOL_K & $-2,50$ & 0,01 \\
\hline GWQMN & $-3,29$ & 0,00 \\
\hline CN2 & $-3,92$ & 0,00 \\
\hline SOL_AWC & $-11,59$ & 0,00 \\
\hline
\end{tabular}

Na avaliação de sensibilidade dos parâmetros do balanço hídrico, Kannan et al. (2007) constatou que o parâmetro SOL_AWC (capacidade de água disponível) apresentava uma relação inversa com os componentes do balanço hídrico. Dessa forma, um aumento no valor desse parâmetro, implicará na redução do fluxo de base e do escoamento superficial, resultando na diminuição do volume de vazão. Pelo fato de exercer uma grande influência nos componentes do balanço hídrico, o SOL_AWC é um parâmetro que apresenta alto nível de sensibilidade e grande significância em boa parte dos estudos envolvendo análise de sensibilidade. De forma prática, o ajuste desse parâmetro pode melhorar a eficiência da modelagem para vazão, tanto em casos de valores subestimados, quanto para superestimados.

Vale ressaltar que o ajuste do modelo para a vazão, não depende unicamente do SOL_AWC, mais sim do conjunto de outros parâmetros. Neste sentido, destaca-se a necessidade de realizar a análise de sensibilidade.

De acordo com Arnold et al. (2012) o parâmetro CN2 exerce influência direta no processo de escoamento superficial. Qualquer alteração nesse processo, implica em mudanças nos componentes do balanço hídrico, que consequentemente, serão refletidas nos processos de erosão do solo e transporte de nutrientes. Este é o principal motivo pelo qual a maioria dos 
métodos descritos de calibração para o SWAT, recomendam inicialmente ajustes para vazão, em seguida para os sedimentos e finalmente calibrar nutrientes e pesticidas. Os autores ainda destacam, a importância dos parâmetros CN2, AWC, ESCO, e SURLAG, utilizados usualmente para a calibração da vazão.

Segundo Kannan et al. (2007), o parâmetro GWQMN influencia os valores de vazão, pois está relacionado com a dinâmica do fluxo de base. Desse modo, um aumento dos valores GWQMN, resulta em um atraso do fluxo de base e seu armazenamento. Já a redução dos valores de GWQMN, promove um aumento no fluxo de base. Os mesmos autores explicam que o parâmetro SOL_K é extremamente importante para as simulações no período de estiagem, pois controla o fluxo horizontal na zona saturada, podendo interferir no escoamento de base.

\subsubsection{Calibração da Modelagem}

O procedimento de calibração foi realizado de forma automática por meio de 1000 interações, envolvendo os 11 parâmetros e os respectivos intervalos estabelecidos pela análise de sensibilidade. A calibração foi realizada mensalmente, durante o período de 01/01/2004 a 31/12/2010, totalizando 84 valores observados de vazão, próximo ao exutório da microbacia.

A Tabela 7 mostra os resultados do melhor ajuste para os parâmetros, obtidos pela calibração.

Tabela 7. Parâmetros, métodos, intervalos e valores resultantes da calibração para a microbacia.

\begin{tabular}{|c|c|c|c|c|c|c|}
\hline \multirow[t]{2}{*}{ Parâmetro } & \multirow{2}{*}{$\begin{array}{l}\text { Valores } \\
\text { Iniciais }\end{array}$} & \multirow{2}{*}{$\begin{array}{c}\text { Tipo de } \\
\text { Alteração } \\
\mathbf{R}(X) \mathbf{V}(=) \\
\end{array}$} & \multicolumn{2}{|c|}{ Intervalo } & \multirow{2}{*}{$\begin{array}{c}\text { Valores } \\
\text { da } \\
\text { Calibração }\end{array}$} & \multirow{2}{*}{$\begin{array}{c}\text { Resultados } \\
\text { da } \\
\text { Calibração }\end{array}$} \\
\hline & & & Máx & Mín & & \\
\hline $\begin{array}{c}\mathbf{R}-\mathbf{S O L} \mathbf{K} \\
(\mathbf{m m} / \mathbf{h r})\end{array}$ & $\begin{array}{l}125 \\
\text { (méd) }\end{array}$ & $X$ & $-0,1$ & $-0,25$ & 0,101 & 137,62 \\
\hline $\begin{array}{c}\mathrm{V}- \\
\underset{\text { (Dias) }}{\text { ALPHA_BF }}\end{array}$ & 0,048 & $=$ & 0 & 0,3 & 0,02575 & 0,02575 \\
\hline $\begin{array}{c}\text { V - CH_N2 } \\
\text { (Adim) }\end{array}$ & 0,014 & $=$ & 0,05 & 0,25 & 0,145 & 0,145 \\
\hline
\end{tabular}




\begin{tabular}{|c|c|c|c|c|c|c|}
\hline $\begin{array}{c}\text { V - GWQMN } \\
(\mathbf{m m})\end{array}$ & 0 & $=$ & 0,4 & 0,8 & 0,530 & 0,530 \\
\hline $\begin{array}{c}\mathbf{V} \text { - CH_K2 } \\
(\mathrm{mm} / \mathrm{hr})\end{array}$ & 0 & $=$ & 0 & 10 & 4,25 & 4,25 \\
\hline $\begin{array}{c}\text { V - } \\
\text { ALPHA_BNK } \\
\text { (Dias) }\end{array}$ & 0 & $=$ & 0,25 & 0,5 & 0,306 & 0,306 \\
\hline $\begin{array}{c}\mathbf{V}-\text { ESCO } \\
\text { (Adim) }\end{array}$ & 0 & $=$ & 0,2 & 0,4 & 0,245 & 0,245 \\
\hline $\begin{array}{l}\text { R - CN2 } \\
\text { (Adim) }\end{array}$ & $\begin{array}{c}68 \\
\text { (méd) }\end{array}$ & $X$ & $-0,45$ & $-0,25$ & $-0,22$ & 53,04 \\
\hline $\begin{array}{c}\text { V - } \\
\text { GW_DELAY } \\
\text { (Dias) }\end{array}$ & 31 & $=$ & 80 & 350 & 156 & 156 \\
\hline $\begin{array}{c}\text { V - } \\
\text { GW_REVAP } \\
(\text { Adim) }\end{array}$ & 0,02 & $=$ & 0,05 & 0,17 & 0,167 & 0,167 \\
\hline R - SOL_AWC & $\begin{array}{c}0,34 \\
\text { (méd) }\end{array}$ & $X$ & 0,2 & 0,5 & 0,462 & 0,49 \\
\hline
\end{tabular}

$\mathbf{R}(\mathbf{X})$ multiplicar; $\mathbf{V}(=)$ igualar e méd. (alguns parâmetros possuem valores que variam entre tipos de solo e camadas, portanto, atribui-se o valor médio).

Analisando os resultados obtidos pela calibração, constatou-se que 9 dos 11 parâmetros utilizados nesse procedimento, receberam um acréscimo em seus valores. Dentre esses estão: SOL_AWC, GWQMN, SOL_K, ALPHA_BNK, ESCO, CH_K2, GW_REVAP, CH_N2 e GW_DELAY.Os maiores acréscimos foram registrados para os parâmetros CH_N2 e GW_REVAP respectivamente. Os parâmetros CN2 e, ALPHA_BF sofreram um decréscimo, segundo os valores obtidos pela calibração.

A seguir, são apresentados na Figura 25 os hidrogramas das vazões calibradas e dos dados observados para a modelagem da Microbacia Cana do Reino. 


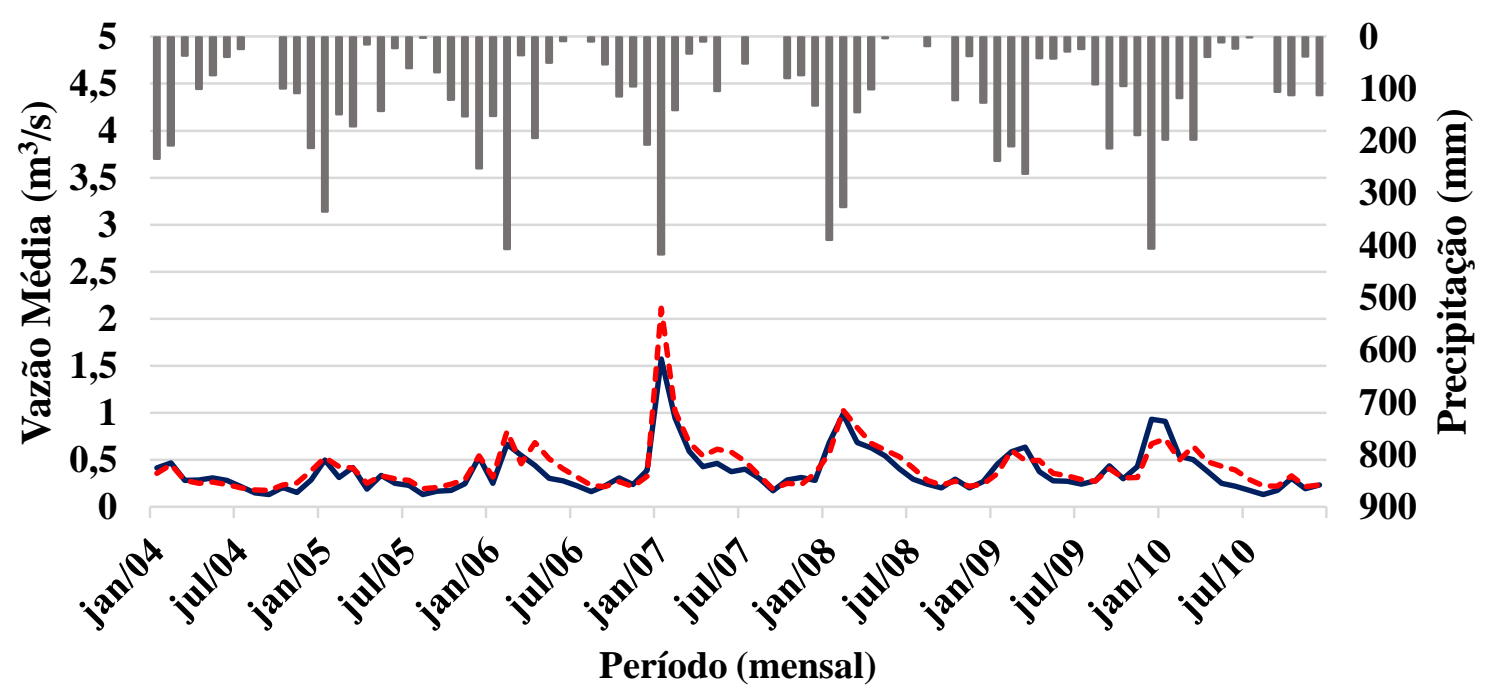

Precipitação mensal

Vazão Observada (6B - 012 DAEE)

Vazão Simulada (Calibrada)

Figura 25. Hietograma e hidrogramas observado e simulado (calibrado) mensal para o período de 2004 a 2010.

Após a calibração, notou-se uma significativa melhora da modelagem na simulação de vazão, se comparado a simulação sem calibração Figura 26, e aos valores observados.

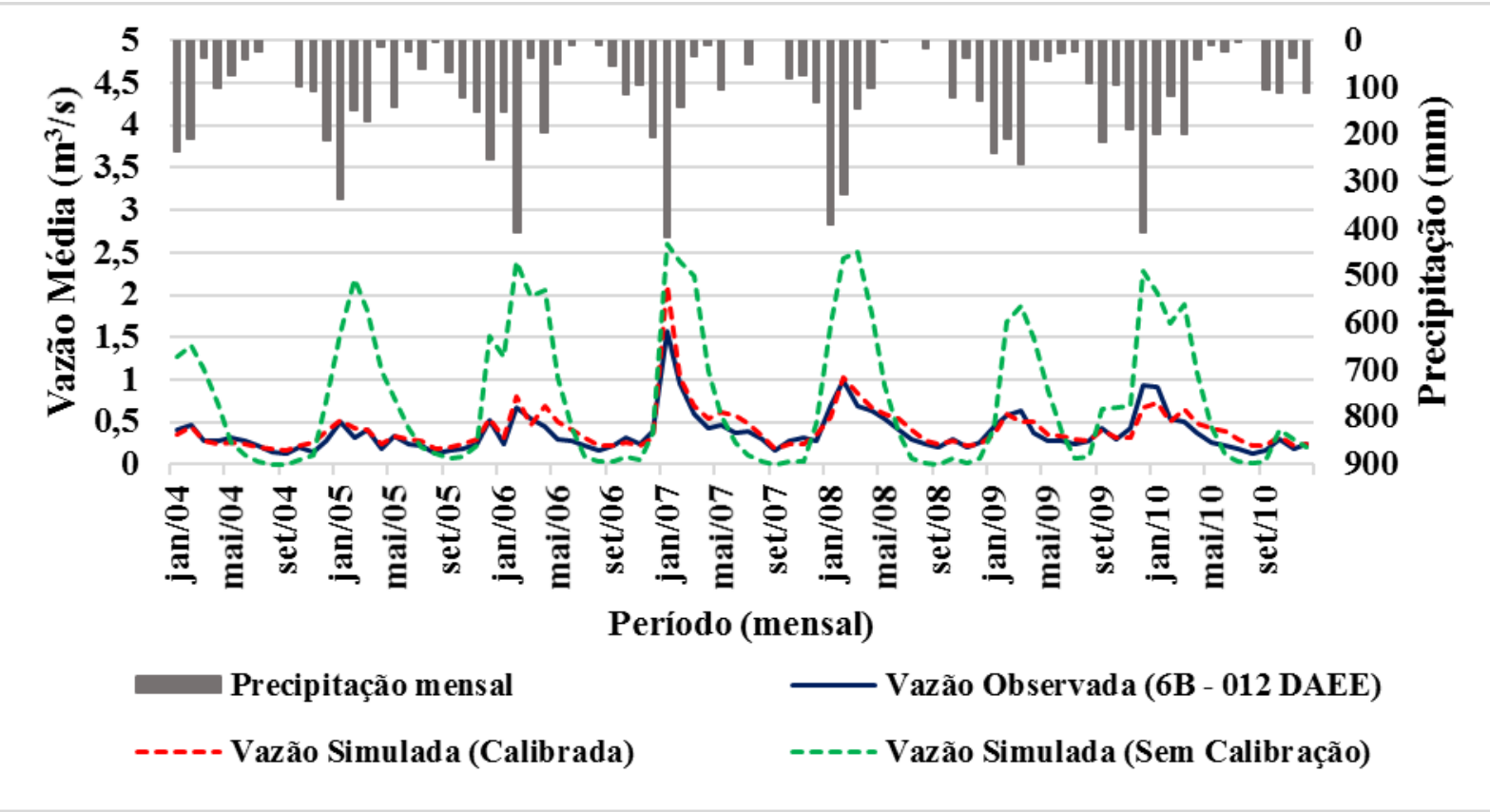

Figura 26. Hietograma e hidrogramas observado, simulado (calibrado) e (sem calibração) mensal para o período de 2004 a 2010. 
A melhora do desempenho da modelagem também pode ser observada no gráfico de dispersão dos valores simulados e observados (Figura 27).

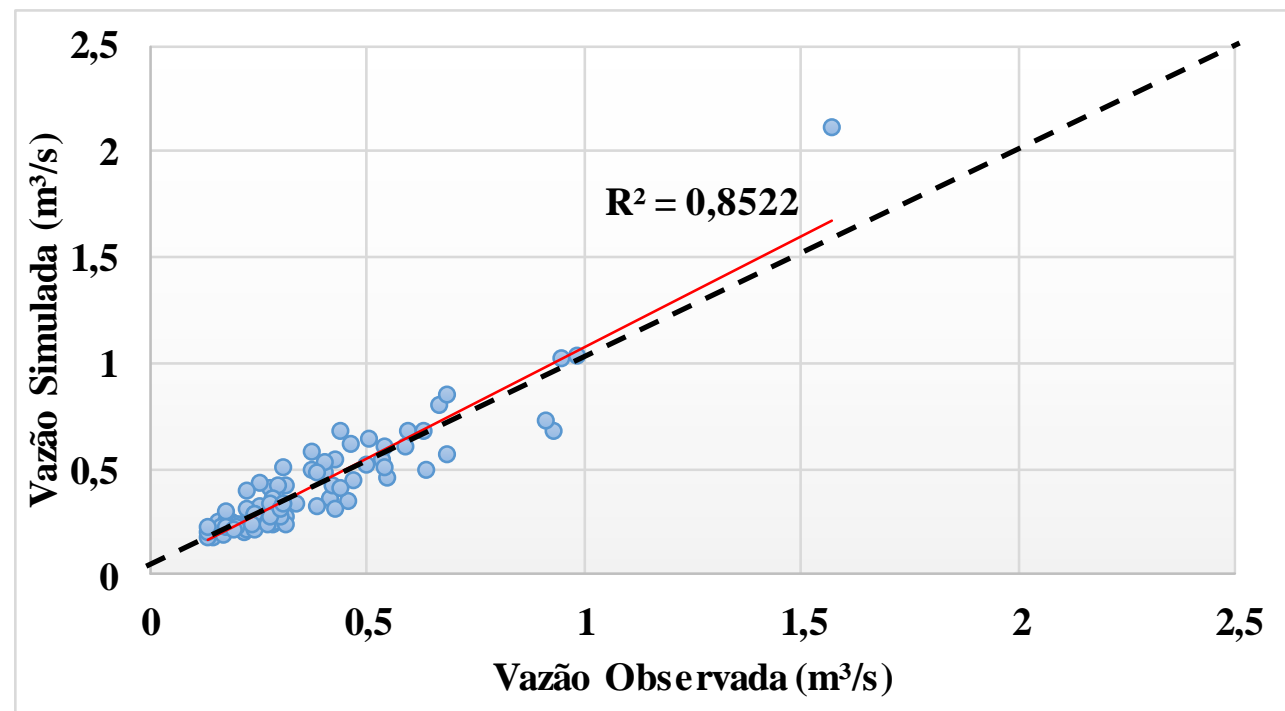

Figura 27. Diagrama de dispersão das vazões médias mensais observadas e simuladas (calibrado) para o período de 2004 a 2010 na microbacia.

Os resultados dos coeficientes de determinação $\left(\mathrm{R}^{2}\right)$, índice de Nash-Sutcliffe (NSE) e do percentual de tendências (PBIAS) após a calibração, foram respectivamente de $0,85,0,82$ e -1,5. Esses valores demonstram estatisticamente o progresso da simulação em relação aos valores não calibrados $(0,79,-2,17$ e -94,6). Observa-se que a simulação antes da calibração estava superestimada em 94,6\% segundo o valor de (PBIAS). Após a calibração esse valor reduziu significativamente para $1,5 \%$ de superestimação em relação aos valores observados. A Tabela 8 apresenta uma avaliação comparativa entre a simulação calibrada e não calibrada, utilizando a classificação dos índices estatísticos Nash-Sutcliffe (NSE) e (PBIAS), proposta por Moriasi et al. (2007).

Tabela 8. Classificação do desempenho para as estatísticas NSE e PBIAS em nível mensal.

\begin{tabular}{cccccc}
$\begin{array}{c}\text { Classificação } \\
\text { de }\end{array}$ & NSE & PBIAS\% & \multicolumn{2}{c}{$\begin{array}{c}\text { Simulação } \\
\text { Calibrada }\end{array}$} & $\begin{array}{c}\text { Simulação } \\
\text { não } \\
\text { Calibrada }\end{array}$ \\
\cline { 4 - 6 } \cline { 4 - 6 } & & & NSE & PBIAS & NSE PBIAS \\
\hline Muito bom & $0,75<$ NSE $\leq 1,00$ & PBIAS $< \pm 10$ & 0,82 & $-1,5$ & \\
\hline Bom & $0,65<$ NSE $\leq 0,75$ & $\pm 10<$ PBIAS $< \pm 15$ & & & \\
\end{tabular}




\begin{tabular}{ccccc}
\hline Satisfatório & $0,50<\mathrm{NSE} \leq 0,65$ & $\pm 15<\mathrm{PBIAS}< \pm 25$ & & \\
\hline Insatisfatório & $\mathrm{NSE} \leq 0,50$ & $\mathrm{PBIAS}> \pm 25$ & $-2,17$ & $-94,6$ \\
\hline
\end{tabular}

Conforme a classificação proposta por Moriasi et al. (2007), os índices estatísticos para a simulação calibrada classificaram-se como sendo "Muito bom". Já os valores para os mesmos índices da simulação sem calibração, enquadraram-se como sendo "Insatisfatórios".

\subsubsection{Verificação}

Depois de realizar a calibração da modelagem e aplicar os testes estatísticos para avaliar o desempenho da mesma, durante o período calibrado, o modelo ajustado foi submetido a um novo período de teste para a verificação.

A etapa de verificação para esse estudo foi realizada para um total de 4 anos contínuos, correspondendo ao período de 01/01/2011 a 31/12/2014, utilizando o software SWATCUP. A Figura 28 apresenta os hidrogramas do período de verificação e dos valores observados.

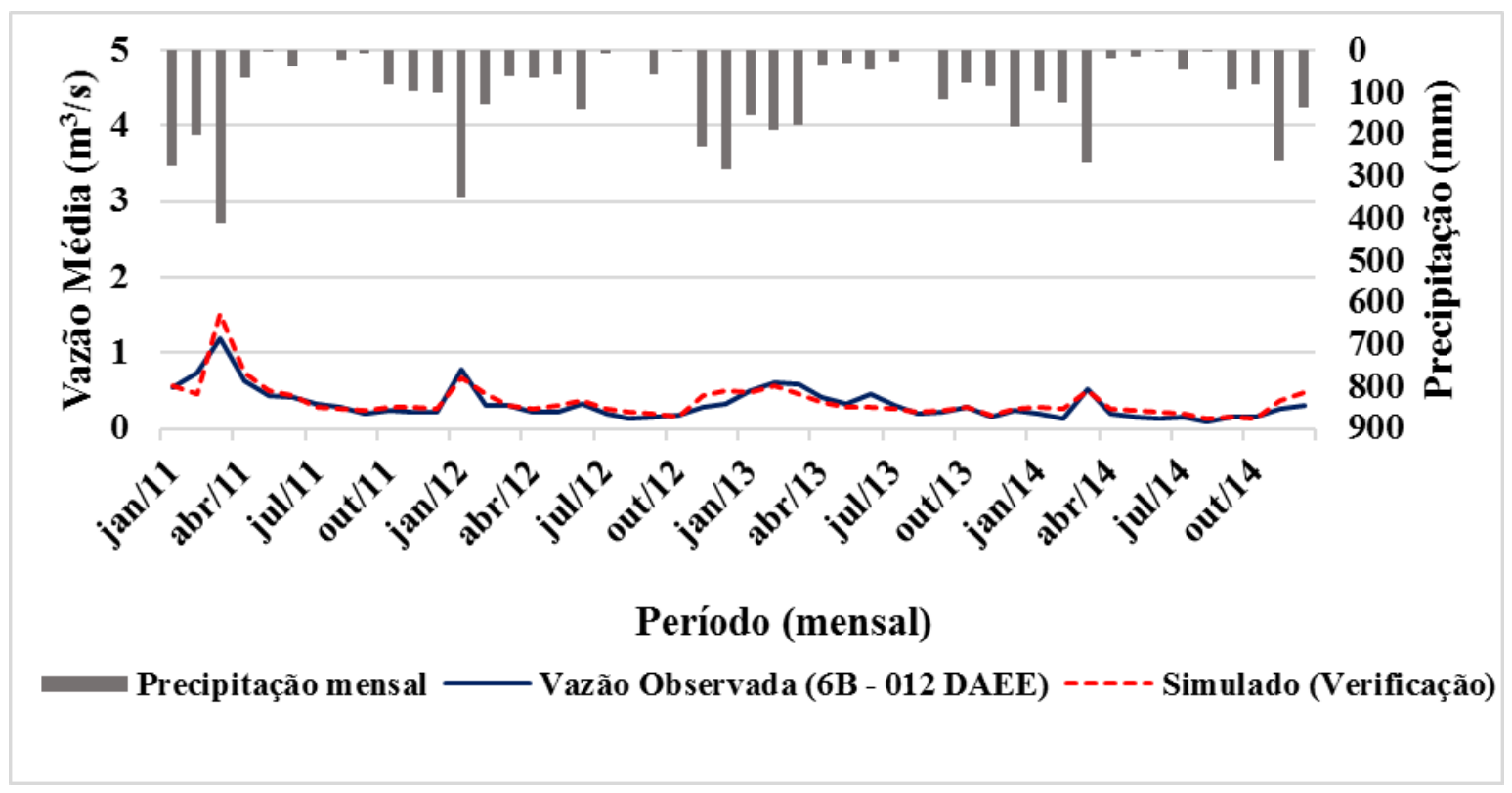

Figura 28. Hietograma e hidrogramas observado e simulado mensal para o período de verificação de 2011 a 2014. 
Em uma análise preliminar dos hidrogramas, infere-se que o padrão de resposta entre a modelagem calibrada e os dados observados de vazão, mantiveram-se para o período de verificação. A Figura 29 apresenta o gráfico com a dispersão dos pontos de vazão simulado e observado para o período de verificação.

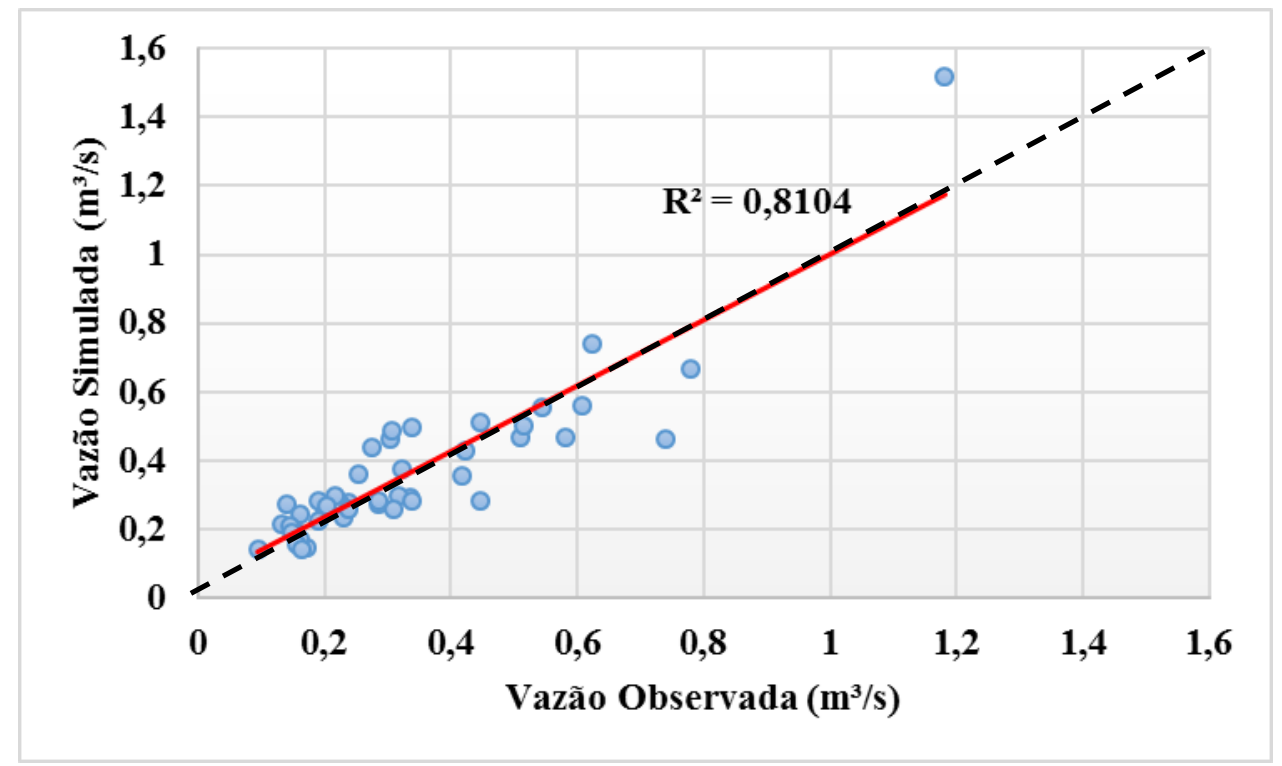

Figura 29. Diagrama de dispersão das vazões médias mensais observadas e simuladas para o período de verificação de 2004 a 2010 na microbacia.

Em relação aos índices estatísticos o período de verificação apresentou os seguintes valores para $\mathrm{R}^{2}$, NSE e PBIAS: 0,81, 0,76 -9,0, respectivamente. Por estes valores observa-se que houve uma pequena redução no valor do $\mathrm{R}^{2}$ em comparação ao $\mathrm{R}^{2}$ apresentado pelo período de calibração $(0,85$ para 0,81$)$. Os outros índices foram classificados como "Muito bom”, embora estejam próximos dos limites inferiores desta classificação, conforme Tabela 8. Os valores de PBIAS indicam que a simulação no período de verificação está 9,0\% superestimada em relação aos valores observados.

Diante dos resultados obtidos no período de verificação, pôde-se confirmar estatisticamente a eficiência dos ajustes realizados na etapa de calibração, em melhorar a simulação para a vazão. Desta forma, a modelagem conseguiu representar de forma satisfatória a vazão observada nos períodos de calibração e verificação. 
Em seguida são apresentados os hidrogramas simulado e observado para todo o período de 2004 a 2014, utilizado na modelagem (Figura 30).

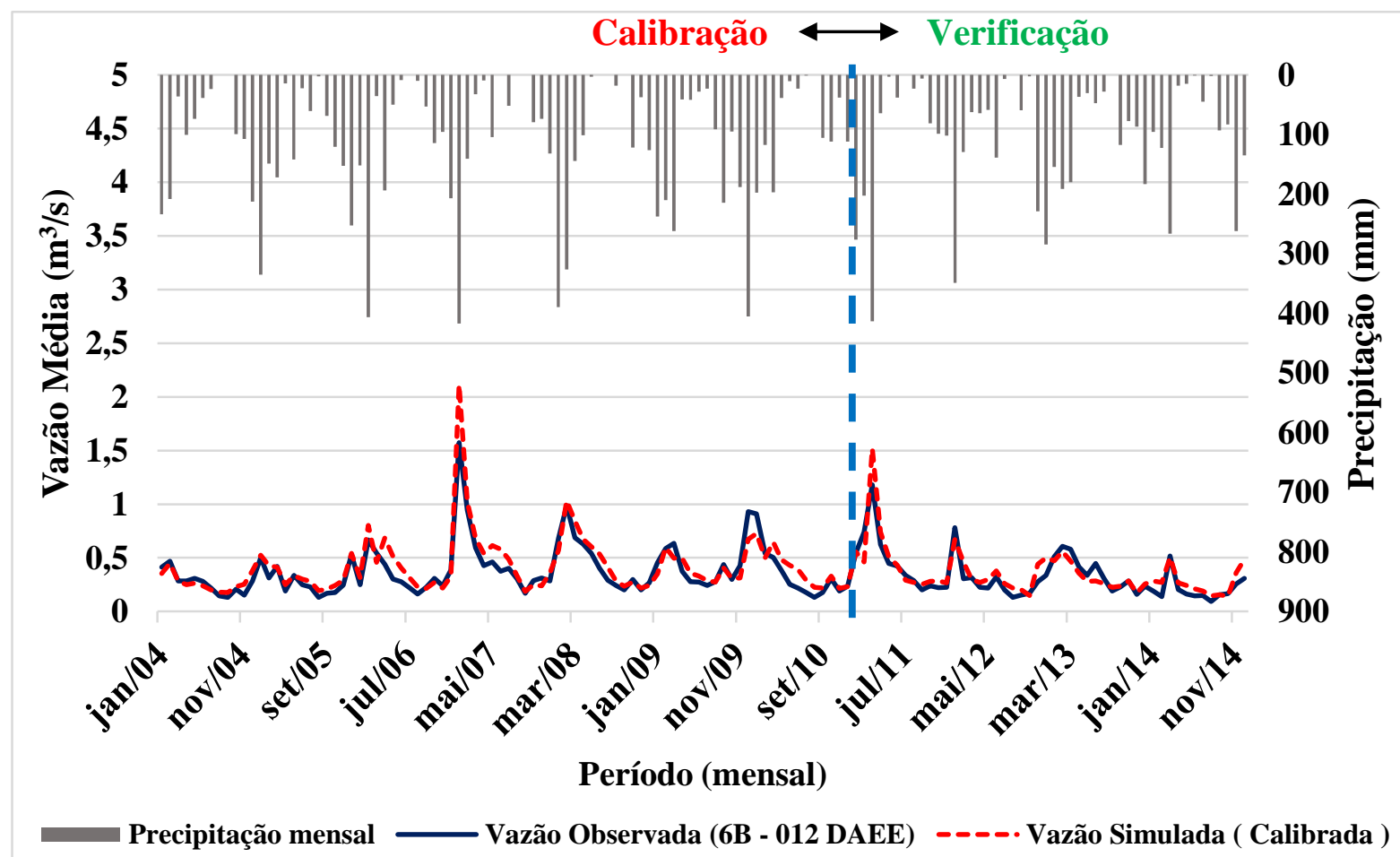

Figura 30. Hietograma e hidrogramas observado e simulado mensal para o período de calibração e verificação de 2004 a 2014.

Por meio da análise gráfica observa-se que as simulações para o período de calibração e verificação apresentaram respostas similares em relação aos dados observados. Constatou-se também que embora tenham apresentado uma pequena diferença entre os índices NSE e PBIAS, esta não refletiu significativamente na simulação. A dispersão dos pontos simulados e observados para este período são apresentados na Figura 31. 


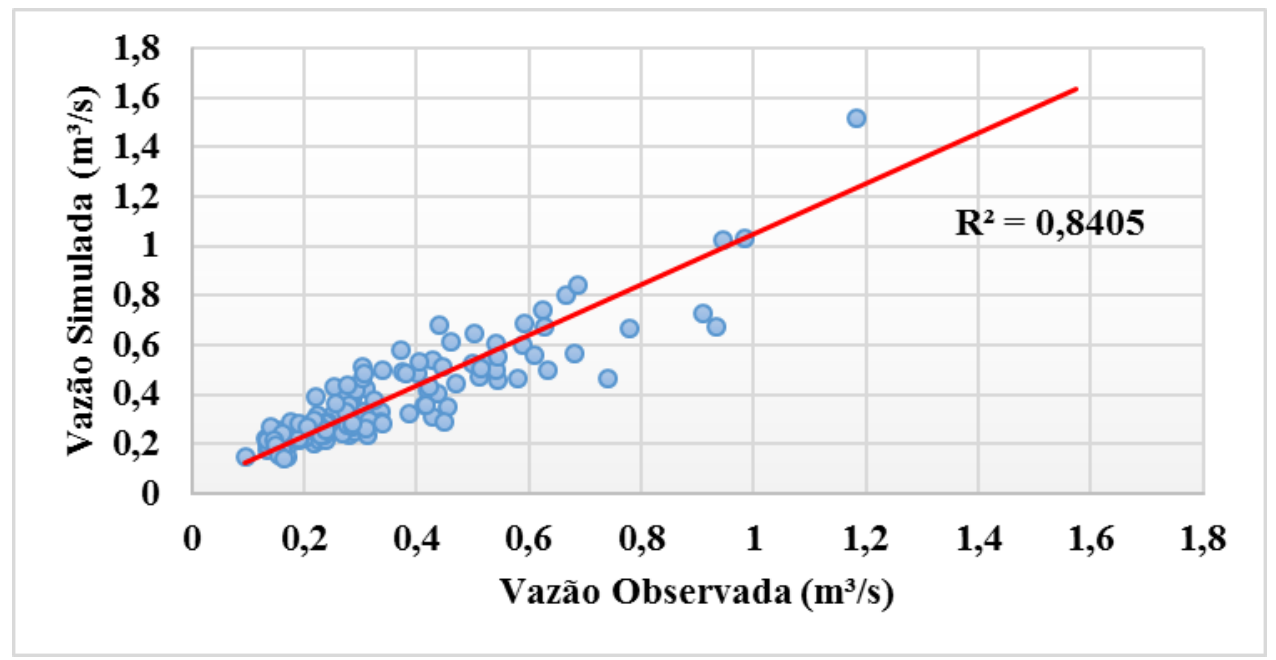

Figura 31. Diagrama de dispersão das vazões médias mensais observadas e simuladas para o período de 2004 a 2010 na microbacia.

Os índices estatísticos $\mathrm{R}^{2}$, NSE e PBIAS para esse período, apresentaram respectivamente os seguintes valores: $0,84,0,80$ e $-3,4$. Nota-se que para o coeficiente de determinação $\mathrm{R}^{2}$, houve um aumento em relação ao valor obtido no período de validação $(0,80)$ e uma pequena redução se comparado aos valores do período de calibração $(0,85)$. O valor de PBIAS indica que a simulação está superestimada em 3,4\%, em relação aos valores observados. De acordo com os valores dos índices NSE e PBIAS, esta simulação foi classificada como "Muito Boa", conforme a classificação de Moriasi et al. (2007).

A Tabela 9 apresenta uma síntese das análises estatísticas utilizadas para avaliar a precisão das seguintes simulações: Não Calibrada, Calibrada, Verificação e Calibrada (2004 a 2014). Estas avaliações foram feitas a partir de Moriasi et al. (2007).

Tabela 9. Avaliação da precisão das simulações não calibrada, calibrada e verificação e calibrada (2004 a 2014.

$\begin{array}{cccc}\begin{array}{c}\text { Simulação não } \\ \text { Calibrada }\end{array} & \begin{array}{c}\text { Simulação } \\ \text { Calibrada }\end{array} & \text { Verificação } & \begin{array}{c}\text { Calibrada } \\ (2004 \text { a 2014) }\end{array}\end{array}$

\begin{tabular}{ccccccccc}
\hline Índices & NSE & PBIAS & NSE & PBIAS & NSE & PBIAS & NSE & PBIAS \\
\cline { 2 - 9 } estatísticos & $-2,17$ & $-94,6$ & 0,82 & $-1,5$ & 0,76 & $-9,0$ & 0,8 & $-3,4$ \\
\hline $\begin{array}{c}\text { Classificação } \\
\text { de }\end{array}$ & Insatisfatório & Muito bom & Muito bom & Muito bom \\
Desempenho & & & & & & & & \\
\hline
\end{tabular}


Com o término desta etapa, obteve-se a calibração do modelo hidrológico para a microbacia em estudo. Esta condição permitiu atribuir maior confiabilidade nas estimativas de escorrimento superficial e na produção de sedimento, realizadas para os cenários de 2005 e 2014

\subsection{Análise comparativa entre os cenários de 2005 e 2014}

O cenário de 2005 (Figura 17) representa o período que antecede a expansão da cana-de-açúcar na microbacia, sendo esta ocupada por grandes áreas de pastagem nesse período. Já o cenário de 2014 (Figura 20) retrata a expansão da cana-de-açúcar sobre as áreas de pastagem da microbacia, ocorrida nos últimos dez anos.

Inicialmente, foram estimados os valores de escorrimento superficial utilizando o ano base de 2011, para os dois cenários. A Figura 32 apresenta as estimativas de escorrimento superficial da microbacia para o cenário de 2005. 


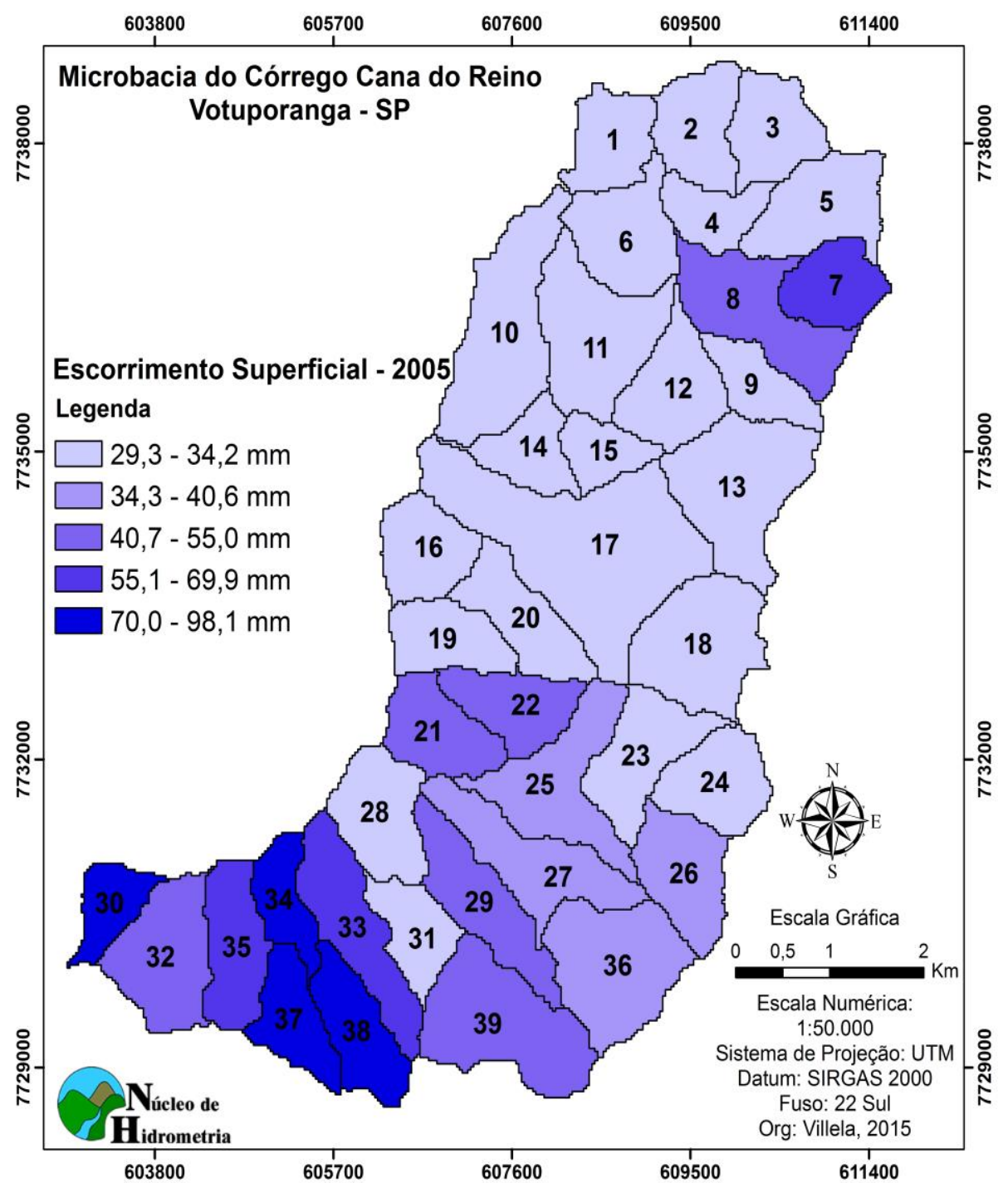

Figura 32. Mapa da produção de escorrimento superficial para o cenário de 2005.

Analisando a Figura 32, constata-se que a maioria das sub-bacias situadas na porção norte da microbacia apresentaram as menores taxas de escorrimento superficial, sendo o menor valor $(29,3 \mathrm{~mm})$ observado na sub-bacia 14 . Este valor deve-se ao grande potencial de interceptação da precipitação, devido à presença de vegetação e do cultivo de seringueira na sub-bacia. Além de contribuir para a redução do escorrimento superficial, o processo de interceptação protege o solo contra o impacto das gotas das chuvas, reduzindo os processos erosivos local.

De forma prática, estas condições estão associadas aos tipos de uso do solo e refletem no valor de $\mathrm{CN}$, variável da (Equação 3). Este fator está relacionado ao potencial de 
produção de escorrimento superficial. Como os valores do $\mathrm{CN}$ para vegetação e seringueira são respectivamente 55 e 59, sendo considerados baixos, esses usos contribuem para um CN global baixo da sub-bacia 14, resultando em um baixo escorrimento.

Além do uso do solo, o relevo foi outro fator contribuinte para a baixa produção de escorrimento. Verificou-se que $70 \%$ do relevo da sub-bacia 14 , é constituído pelas classes "plano" e "suave ondulado". Essas condições permitem que a água escoe de forma mais lenta na superfície do solo, proporcionando maior infiltração. As outras sub-bacias que apresentaram baixos valores de escorrimento são ocupadas por grandes áreas de pastagem e pequenos fragmentos de vegetação. O valor do CN para a pastagem é o mesmo da seringueira, fato que explica a baixa produção de escorrimento nestas sub-bacias.

Os maiores valores de escorrimento superficial foram observados, em grande parte, nas sub-bacias localizadas na porção sul da microbacia. A sub-bacia 34 apresentou a maior taxa $(98,1 \mathrm{~mm})$, seguida respectivamente pelas sub-bacias 30,38 e 37 . O aumento na produção de escorrimento nesta região está relacionado a presença do cultivo de cana-de-açúcar nas sub-bacias. Este cultivo possui um alto valor de CN (igual a 72), sendo inferior apenas ao cultivo do milho com $\mathrm{CN}$ igual a 77. A influência do tipo de uso nas taxas de escorrimento pode ser verificada na sub-bacia 34, onde o cultivo da cana-de-açúcar está presente em mais de $70 \%$ da área. Nas sub-bacias 7, 8, 30, 37 e 38, o cultivo também se faz presente, no entanto, em menor intensidade.

De modo geral, o valor médio de escorrimento superficial para as sub-bacias do cenário de 2005 foi de $44 \mathrm{~mm}$. Verificou-se também que em 57\% da área da microbacia (2.414 ha), a produção de escorrimento variou de 29,0 a 34,2 mm. Para o restante da área (1.802 ha), a produção de escorrimento superficial variou de 34,3 a $98,0 \mathrm{~mm}$, sendo que em 15\% desta área (271 ha), a produção média de escorrimento foi de 87,23 mm. 
Para o cenário de 2014, observa-se um significativo aumento nas taxas de escorrimento superficial, em relação ao cenário de 2005, conforme (Figura 33).

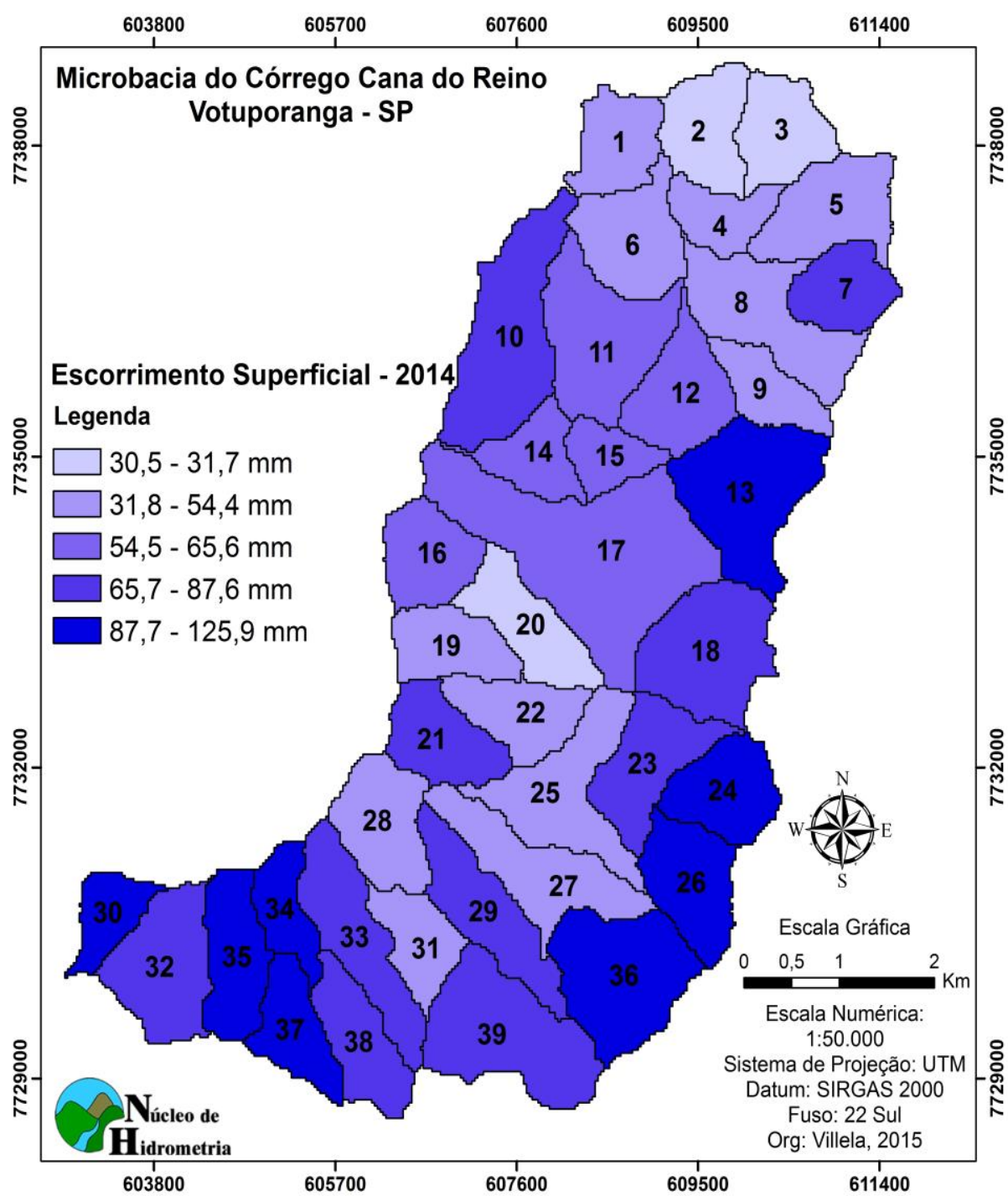

Figura 33. Mapa da produção do escorrimento superficial para o cenário de 2014.

O aumento da produção do escorrimento foi verificado em quase toda área da microbacia, com exceção das sub-bacias 2, 3 e 20 que mantiveram os baixos valores observados no cenário de 2005. Este comportamento pode ser explicado pelo uso nas sub-bacias, composto por áreas de pastagens, seringueira e vegetação, que apresentam baixo potencial de escorrimento.

As sub-bacias $13,24,26,30,34,36$ e 37 , apresentaram as maiores taxas de escorrimento, que variaram de 87,6 a $125,9 \mathrm{~mm}$, sendo o maior valor observado na sub-bacia 
26. Estes valores são atribuídos a presença de grandes áreas com cana-de-açúcar. Verificou-se que estas sub-bacias ocupam uma área de 792 ha, o equivalente a 19\% da área da microbacia. Outros valores significativos foram encontrados nas sub-bacias 18, 7, 10, 23, onde verificouse respectivamente $83,82,76$ e $75 \mathrm{~mm}$ de escorrimento. Nestas sub-bacias o cultivo da canade-açúcar aparece em menor intensidade. Constatou-se também que em 50\% da área da microbacia (2.108 ha) a produção de escorrimento varia de 54,5 a $87 \mathrm{~mm}$ e que em 1.132 ha, a variação é de 31 a 54,4 mm.

O aumento do escorrimento superficial para este cenário, está relacionado a expansão do cultivo da cana-de-açúcar na microbacia. Com esta expansão, 1.438 ha de pastagens foram convertidos em áreas de cana-de-açúcar. Esta conversão aumentou o potencial de produção de escorrimento nas sub-bacias que alocaram as demandas do cultivo. Desta forma, verifica-se uma alteração no valor de $\mathrm{CN}$ de 59 para 72 em 34\% da área da microbacia, explicando assim, o aumento das taxas de produção de escorrimento para o cenário de 2014.

Em comparação com o cenário de 2005, constatou-se que a média de escorrimento superficial recebeu um aumento de aproximadamente 59\%, passando de $44 \mathrm{~mm}$ no antigo cenário para $70 \mathrm{~mm}$ em 2014. Em 57\% da área da microbacia $(2.414 \mathrm{ha})$, as taxas de escorrimento em 2005 variavam de 29,0 a 34,2 mm, já no cenário de 2014 estes valores variam de 30,5 a $106 \mathrm{~mm}$. As sub-bacias 30, 34, 37 e 38 que apresentaram as maiores taxas em 2005 tiveram um aumento de 12,6\% na produção média de escorrimento, passando de 87 para 98.

Após comparar a produção de escorrimento superficial dos cenários de 2005 e 2014, são apresentadas, a seguir, as estimativas de produção de sedimentos para os dois cenários.

Na Figura 34 são apresentadas as estimativas de produção de sedimentos para o cenário de 2005 . 


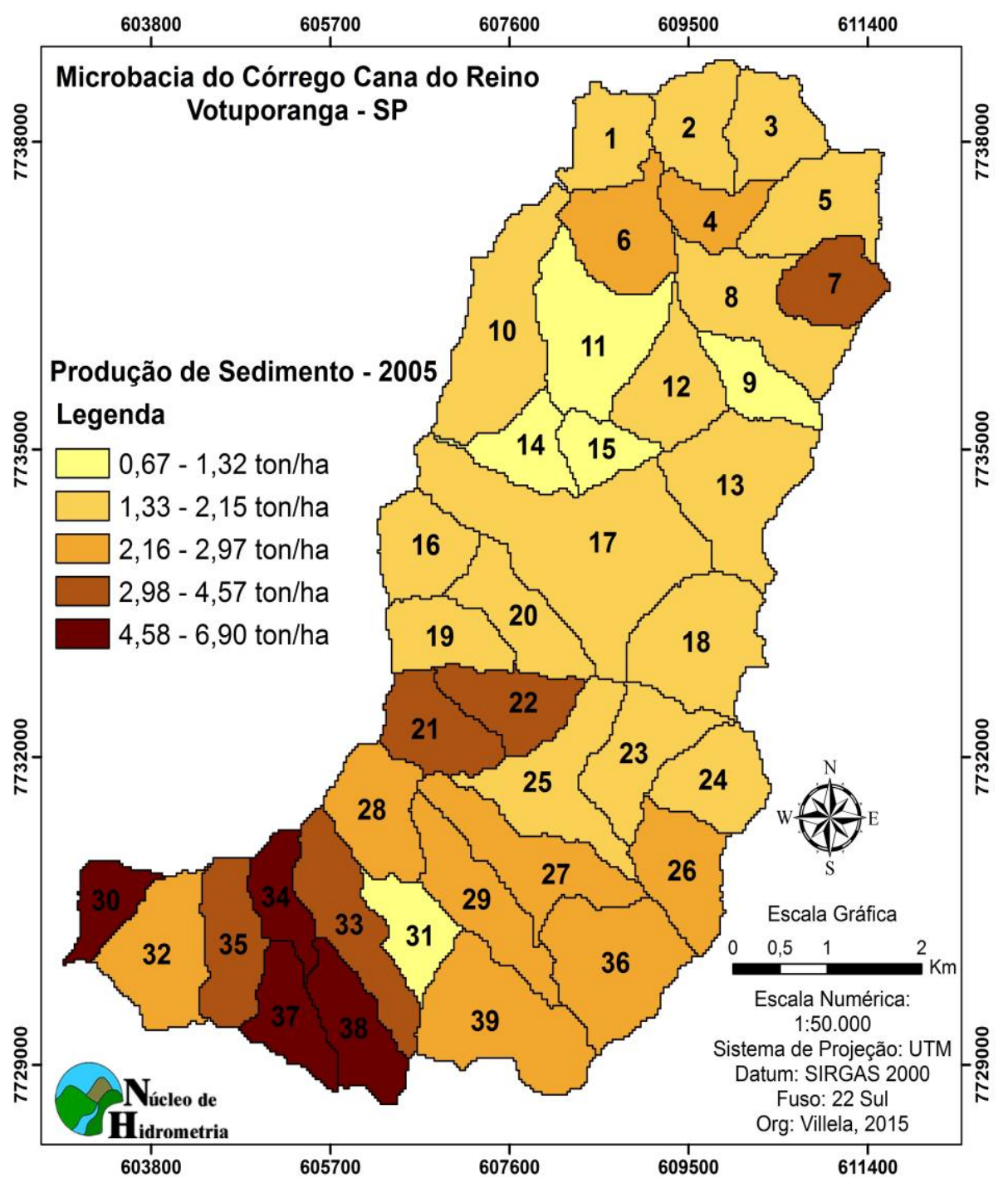

Figura 34. Mapa da produção de sedimentos para o cenário de 2005.

$\mathrm{Na}$ Figura 34, nota-se que as menores taxas de produção de sedimento foram registradas nas sub-bacias $9,11,14,15$ e 31 , sendo o menor valor observado nesta última. A baixa produção para a sub-bacia 31 está associada à presença de vegetação em $81 \%$ da área. Esta área contribui para a redução do escorrimento superficial, resultando em menores taxas de produção de sedimentos, que de forma prática são verificadas nos baixos valores do fator de uso e cobertura do solo (fator C), para a vegetação.

Já os valores observados nas sub-bacias 9, 11, 14, 15 estão relacionados aos baixos valores do fator $\mathrm{C}$, atribuídos a pastagem, seringueira e a vegetação existentes na área, além do predomínio das baixas declividades que variam de 0 a $8 \%$. 
Nota-se que a maioria das sub-bacias apresentou taxas variando de 1,33 a 2,15 ton.ha ${ }^{-1} \cdot$ ano $^{-1}$ e estão localizadas nas regiões norte e central da microbacia. Estas subbacias estão localizadas majoritariamente sobre solos do tipo Latossolo Vermelho Eutrófico textura média-arenosa (LVPe md-ar), que apresentam o menor coeficiente de erodibilidade (fator K) dentre os solos da microbacia. Este parâmetro pode explicar os valores relativamente baixos obtidos nestas sub-bacias, e constatar a influência das classes de solo sobre a produção de sedimentos. Tal influência é evidenciada comparando as taxas de produção das sub-bacias 23 e 24 inseridas sobre (LVPe md-ar) com fator K de 0,0167 e com as 26 e 36 circunscritas sobre Argissolo Vermelho Eutrófico textura arenosa média (PVe ar/md) com fator K igual a 0,0228. Vale ressaltar que as sub-bacias comparadas apresentam características semelhantes de uso do solo e declividade.

De forma análoga as taxas de escorrimento, os maiores valores de produção de sedimentos foram observados nas sub-bacias situadas na porção sul da microbacia. Verificase que as sub-bacias $30,34,37$ e 38 registraram as maiores taxas, sendo o maior valor 6,90 ton/ha produzido pela sub-bacia 38. Este valor pode ser justificado, por grande parte desta sub-bacia estar inserida sobre (PVe ar/md) que possui um elevado coeficiente de erodibilidade. O uso e ocupação também contribuiu para o maior valor, pois a sub-bacia é ocupada por grandes áreas com cana-de-açúcar, que apresenta o maior valor do fator $\mathrm{C}$, dentre os usos existentes na microbacia. As sub-bacias 30 e 34 também são ocupadas por grandes áreas com cana, porém estão inseridas em um tipo de solo com um menor coeficiente de erodibilidade.

Constatou-se que a produção média de sedimentos para as sub-bacias do cenário de 2005 foi de 2,6 ton.ha ${ }^{-1}$.ano ${ }^{-1}$. Verificou-se que em $48 \%$ da área da microbacia (2.022 ha) a produção de sedimento variou de 1,33 a 2,15 ton.ha ${ }^{-1}$.ano ${ }^{-1}$. Já as áreas de maior e menor produção correspondem respectivamente a 271 e 403 ha. 
A avaliação das taxas de produção de sedimentos para a microbacia baseou-se no valor de tolerância de perdas de solo (TPS), descritos no estudo de Lima et al. (2015) sobre a erodibilidade dos solos da Bacia Hidrográfica do São José dos Dourados - SP. Comparando os valores de produção de sedimentos para os quatro solos presentes na microbacia, verificou-se que as taxas para o cenário de 2005 são consideradas baixas, pois estão abaixo do limite de tolerância de perdas de solo. No Latossolo Vermelho Eutrófico textura média/arenosa, que ocupa $65,2 \%$ da área da microbacia, a maior taxa registrada foi de 6,54 ton. ha ha $^{-1} \cdot$ ano $^{-1}$, sendo que a tolerância de perdas de solo, corresponde a 11,34 ton.ha ${ }^{-1} \cdot$ ano $^{-1}$. Para o Argissolo Vermelho Eutrófico textura arenosa/argilosa, que está presente em apenas $1,2 \%$ da microbacia, cujo o limite de tolerância de perdas de solo é 3,09 ton.ha ${ }^{-1}$.ano ${ }^{-1}$, o maior valor obtido foi de 1,68 ton.ha ${ }^{-1} \cdot$ ano $^{-1}$. Nos solos situados ao sul da microbacia, Latossolo Vermelho Distrófico textura média e Argissolo Vermelho Eutrófico textura arenosa média que ocupam respectivamente 14,4 e 19,2\% da área da microbacia, o limite de tolerância de perdas de solo para o primeiro é de 12,26 ton.ha $a^{-1} \cdot$ ano $^{-1}$ e para o segundo 9,05 ton.ha- ${ }^{-1} \cdot$ ano $^{-1}$. A produção máxima de sedimentos para estes tipos de solos foram de respectivamente, 6,75 e 6,9 ton.ha ${ }^{-1} \cdot$ ano $^{-1}$.

A seguir são apresentadas na Figura 35 as estimativas de produção de sedimento para o cenário de 2014. 


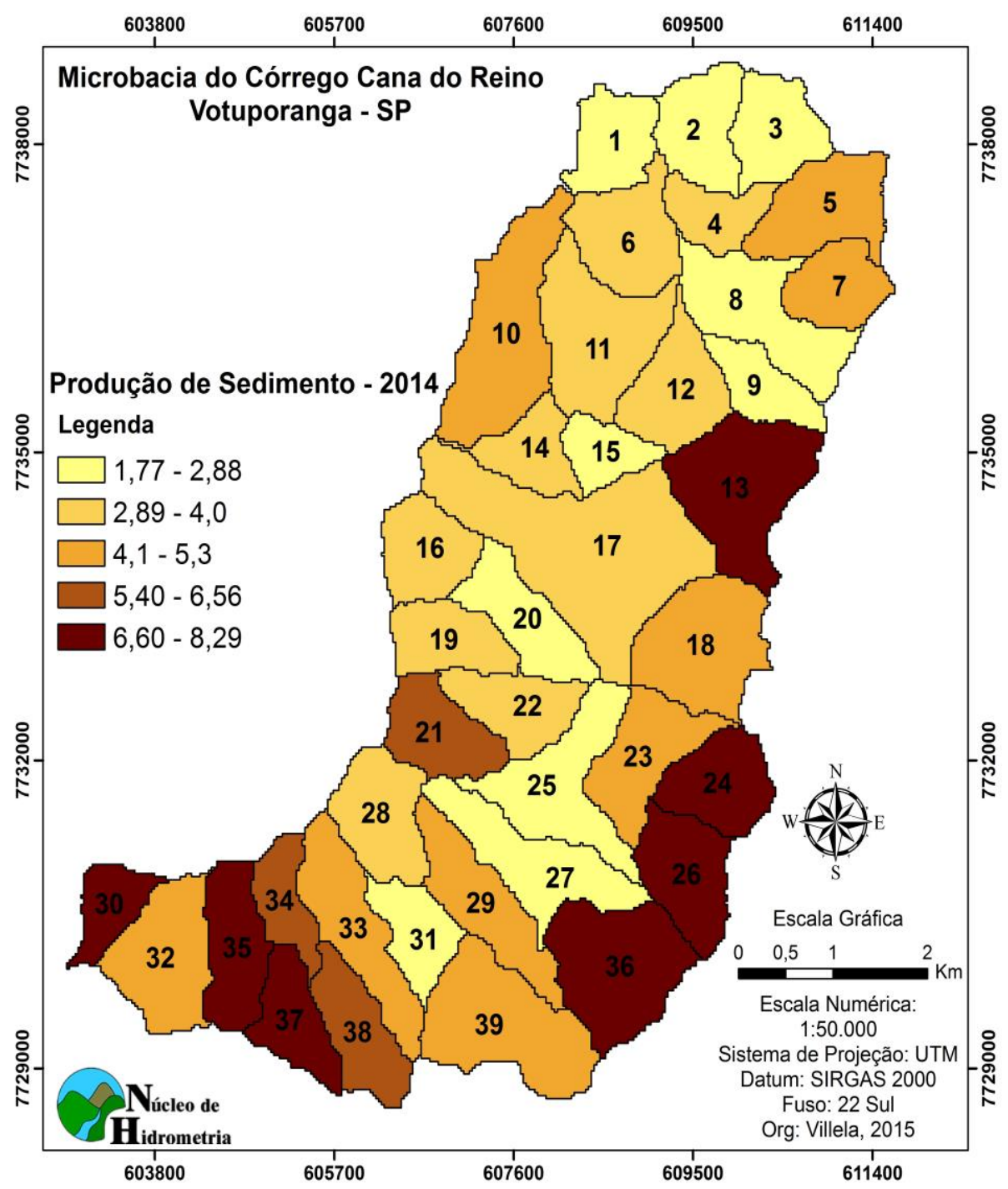

Figura 35. Mapa da produção de sedimentos para o cenário de 2014.

Visualizando a Figura 35 pode-se notar claramente o aumento nas taxas de produção de sedimento para este cenário, conforme indica os limites inferior e superior de produção. As maiores taxas foram verificadas nas sub-bacias $13,24,26,30,34,35,36,37$ e 38 , que juntas ocupam uma área de 880 ha, o equivalente a $21 \%$ da área total da microbacia. Dentre estas, a maior taxa foi registrada pela sub-bacia 26 com uma produção de 8,29 ton.ha ${ }^{-1}$.ano ${ }^{-1}$, seguida pelas taxas das sub-bacias $30,35,37,36,24,13,34$ e 38 . A maior taxa obtida pela sub-bacia 26 pode ser explicada pelo tipo de solo (PVe ar/md), que apresenta elevado coeficiente de erodibilidade, e pelo cultivo de cana-de-açúcar que ocupa $85 \%$ da área desta sub-bacia. Este tipo de cultivo contribui para o alto valor do fator C. Esta combinação foi verificada de forma 
menos expressiva nas sub-bacias 36,37 e 38 , sendo que nestas duas últimas os valores foram influenciados pela presença do Latossolo Vermelho Distrófico textura média ( $\mathrm{LVm} / \mathrm{md}$ ), que possui um menor valor de fator $\mathrm{K}$.

Outras taxas significativas de produção foram observadas nas sub-bacias 18, 21, 32, 33 e 39 , que variaram de 4,69 a 5,72 ton.ha ${ }^{-1}$.ano ${ }^{-1}$, sendo o maior valor observado na subbacia 21. Este valor está associado à presença dos cultivos de milho e cana-de-açúcar, que apresentam altos valores de fator $\mathrm{C}$.

Constatou-se que em $49 \%$ da área da microbacia a produção de sedimento varia de 2,51 a 4,68 ton.ha ${ }^{-1}$. ano ${ }^{-1}$, sendo o limite inferior registrado na sub-bacia 25 e o superior na sub-bacia 5.

As menores taxas foram observadas nas sub-bacias $1,2,3,8,9,20,25,27$ e 31 que estão localizadas em maior proporção na região norte e ocupam o equivalente a $21 \%$ da área da microbacia. Entre estas, a sub-bacia 2 apresentou o menor valor com 1,77 ton.ha ${ }^{-1}$.ano ${ }^{-1}$, que pode estar associado a baixa declividade e a presença de grandes áreas de pastagem e seringueira, que contribuem para o baixo valor do fator $\mathrm{C}$.

Avaliando a produção de sedimento das sub-bacias para o cenário de 2014, constatou-se uma produção média de 4,5 ton.ha ${ }^{-1} \cdot$ ano $^{-1}$, que se comparada à média de produção do cenário de 2005 , verifica-se um aumento de aproximadamente $73 \%$ nestas taxas. Diante deste considerável aumento, nota-se claramente a influência da expansão do cultivo de cana-de-açúcar (324 ha em 2005 para 1762 ha em 2014) sobre as taxas de produção de sedimentos.

Comparando as taxas de produção de sedimentos do cenário de 2014 com os valores de tolerância de perdas de solo descritos por Lima et al. (2015) verifica-se que embora tenha havido um considerável aumento nas taxas de produção, está ultrapassou o limite de TPS somente para o Argissolo Vermelho Eutrófico textura arenosa argilosa. Para este tipo de solo 
registrou-se o valor máximo de 7,2 ton.ha- ${ }^{-1} \mathrm{ano}^{-1}, 1,3$ vezes maior do que o limite de TPS igual a 3,09 ton.ha ${ }^{-1} \mathrm{ano}^{-1}$. Ainda que a produção de sedimentos exceda o limite de TPS para este tipo de solo, tal excesso não contribui de forma significativa com o aporte de sedimentos na microbacia, pois ocupa apenas 1,2\% da área. No entanto, para o Argissolo Vermelho Eutrófico textura arenosa média, que ocupa cerca de 19,2\% da área da microbacia, com produção máxima de 8,29 ton.ha ${ }^{-1}$ ano $^{-1}$, próxima ao limite de TPS de 9,05 ton.ha ${ }^{-1}$ ano $^{-1}$, pode gerar volumes mais significativos no aporte de sedimentos. Para o Latossolo Vermelho Distrófico textura média verificou-se uma produção máxima de 8,2 ton.ha ${ }^{-1} \mathrm{ano}^{-1}$, taxa considerada média em relação ao limite TPS de 12,26 ton.ha- ${ }^{-1} a^{-1}$. A produção máxima de 7,37 ton.ha ${ }^{-1}$ ano $^{-1}$ registrada no Latossolo Vermelho Eutrófico textura média arenosa, também pode ser classificada como média de acordo com o limite de TPS igual a 11,34 ton.ha ${ }^{-1}$ ano $^{-1}$.

De modo geral, as taxas de produção de sedimentos na microbacia pode ser classificada como média, uma vez que em grande parte da microbacia a produção de sedimentos mantém-se em nível médio em relação ao limite TPS, excedendo este limite em apenas $1,2 \%$ da área total da microbacia.

A Tabela 10 apresenta o comparativo da produção de sedimentos entre as sub-bacias dos cenários de 2005 e 2014.

Tabela 10. Produção de sedimentos entre as sub-bacias dos cenários de 2005 e 2014

Produção de sedimentos (ton.ha ${ }^{-1} \cdot$ ano $\left.^{-1}\right)$

Sub-Bacias

Cenário de 2005 Cenário de 2014

\begin{tabular}{lll}
\hline $\mathbf{1}$ & 1,72 & 2,42 \\
\hline $\mathbf{2}$ & 1,68 & 1,77 \\
\hline $\mathbf{3}$ & 1,63 & 1,83 \\
\hline $\mathbf{4}$ & 2,44 & 3,80 \\
\hline $\mathbf{5}$ & 2,06 & 4,68 \\
\hline $\mathbf{6}$ & 2,29 & 3,36 \\
\hline $\mathbf{7}$ & 3,43 & 4,56 \\
\hline $\mathbf{8}$ & 2,15 & 2,27 \\
\hline $\mathbf{9}$ & 1,32 & 2,50 \\
\hline
\end{tabular}




\begin{tabular}{|c|c|c|}
\hline 10 & 1,91 & 4,67 \\
\hline 11 & 1,33 & 3,14 \\
\hline 12 & 1,65 & 3,79 \\
\hline 13 & 1,60 & 7,20 \\
\hline 14 & 0,93 & 3,27 \\
\hline 15 & 0,92 & 2,89 \\
\hline 16 & 1,68 & 3,88 \\
\hline 17 & 1,69 & 3,94 \\
\hline 18 & 1,69 & 4,84 \\
\hline 19 & 1,61 & 4,01 \\
\hline 20 & 1,84 & 1,87 \\
\hline 21 & 4,58 & 5,73 \\
\hline 22 & 3,56 & 3,62 \\
\hline 23 & 1,73 & 4,50 \\
\hline 24 & 2,00 & 7,37 \\
\hline 25 & 2,04 & 2,63 \\
\hline 26 & 2,35 & 8,29 \\
\hline 27 & 2,33 & 2,70 \\
\hline 28 & 2,38 & 3,58 \\
\hline 29 & 2,93 & 4,64 \\
\hline 30 & 6,17 & 8,26 \\
\hline 31 & 0,67 & 2,48 \\
\hline 32 & 2,97 & 5,35 \\
\hline 33 & 4,41 & 5,39 \\
\hline 34 & 6,54 & 6,56 \\
\hline 35 & 4,34 & 8,25 \\
\hline 36 & 2,58 & 7,42 \\
\hline 37 & 5,84 & 7,99 \\
\hline 38 & 6,91 & 7,12 \\
\hline 39 & 2,83 & 4,86 \\
\hline
\end{tabular}

Analisando a Tabela 10 verifica-se que o menor crescimento foi registrado na subbacia 34 , com $0,4 \%$, seguido respectivamente pelo das sub-bacias $2,8,38,22$ e 20 . Nestas sub-bacias não houve alterações significativas em relação ao uso do solo.

A sub-bacia 13 apresentou a maior taxa de crescimento (351\%), passando de 1,60 para 7,20 ton.ha ${ }^{-1} \cdot$ ano $^{-1}$. Tal variação deve-se principalmente a substituição de 137 ha de áreas de pastagem pelo cultivo de cana-de-açúcar, valor equivalente a $82 \%$ da área desta sub-bacia. Esta mudança refletiu positivamente no valor global do fator $\mathrm{C}$, que para a classe de uso pastagem é menor $(0,01)$, em relação ao valor para o cultivo de cana-de-açúcar $(0,3)$. As 
sub-bacias 14, 15, 24, 26 e 31 também apresentaram altas taxas de crescimento, que variaram de 213,8 a 268,5\%. Já as sub-bacias $5,10,11,12,16,17,18,19,23$ e 36 registraram um acréscimo nas taxas de produção de sedimento de 127,0 a 187,8 \%. Outra faixa de variação para essas taxas foram de 12 a 90\%, nas sub-bacias $1,3,4,6,7,9,21,25,27,28,29,30,32$, 33, 35, 37 e 39. Constatou-se que o aumento nas taxas de produção de sedimentos observados, variando de 12 a 268\%, está relacionado ao avanço do cultivo da cana-de-açúcar sobre as áreas de pastagens.

Para evidenciar esta influência selecionou-se duas sub-bacias (24 e 26), que no cenário de 2005 eram ocupadas exclusivamente por áreas de pastagem e vegetação, e que no cenário de 2014 houve a substituição de pastagem por áreas com cana-de-açúcar. Estas sub-bacias registraram um aumento na área de cana-de-açúcar de respectivamente 91 e 92\%, sobre as áreas de pastagens.

A Tabela 11 apresenta a mudança de uso e ocupação ocorrida na sub-bacia 24 entre os cenários de 2005 e 2014, no qual verifica-se o acréscimo de 70,26 ha do cultivo de cana-deaçúcar sobre as áreas de pastagens e a conversão de 1,53 ha de pasto em áreas de vegetação.

Tabela 11. Mudança de uso e ocupação ocorrida na sub-bacia 25 entre os cenários de 2005 e 2014.

\begin{tabular}{|c|c|c|}
\hline Sub-Bacia & Ano 2005 & Ano 2014 \\
\hline \multicolumn{3}{|l|}{24} \\
\hline \multicolumn{3}{|l|}{ Uso e Ocupação do Solo } \\
\hline Cana & Cana-de-açúcar: 0 ha & Cana-de-açúcar: 70,26 ha \\
\hline \multirow{3}{*}{$\begin{array}{l}\text { Pasto } \\
\text { Vegetação }\end{array}$} & Pastagem: 77,29 ha & Pastagem: 5,50 ha \\
\hline & Vegetação: 13,08 ha & Vegetação: 14,61 ha \\
\hline & \multicolumn{2}{|c|}{ Área total: $90,37 \mathrm{ha}$} \\
\hline
\end{tabular}


A Figura 36 apresenta o comparativo das taxas de escorrimento superficial e produção de sedimento entre os cenários de 2005 e 2014 na sub-bacia 24.
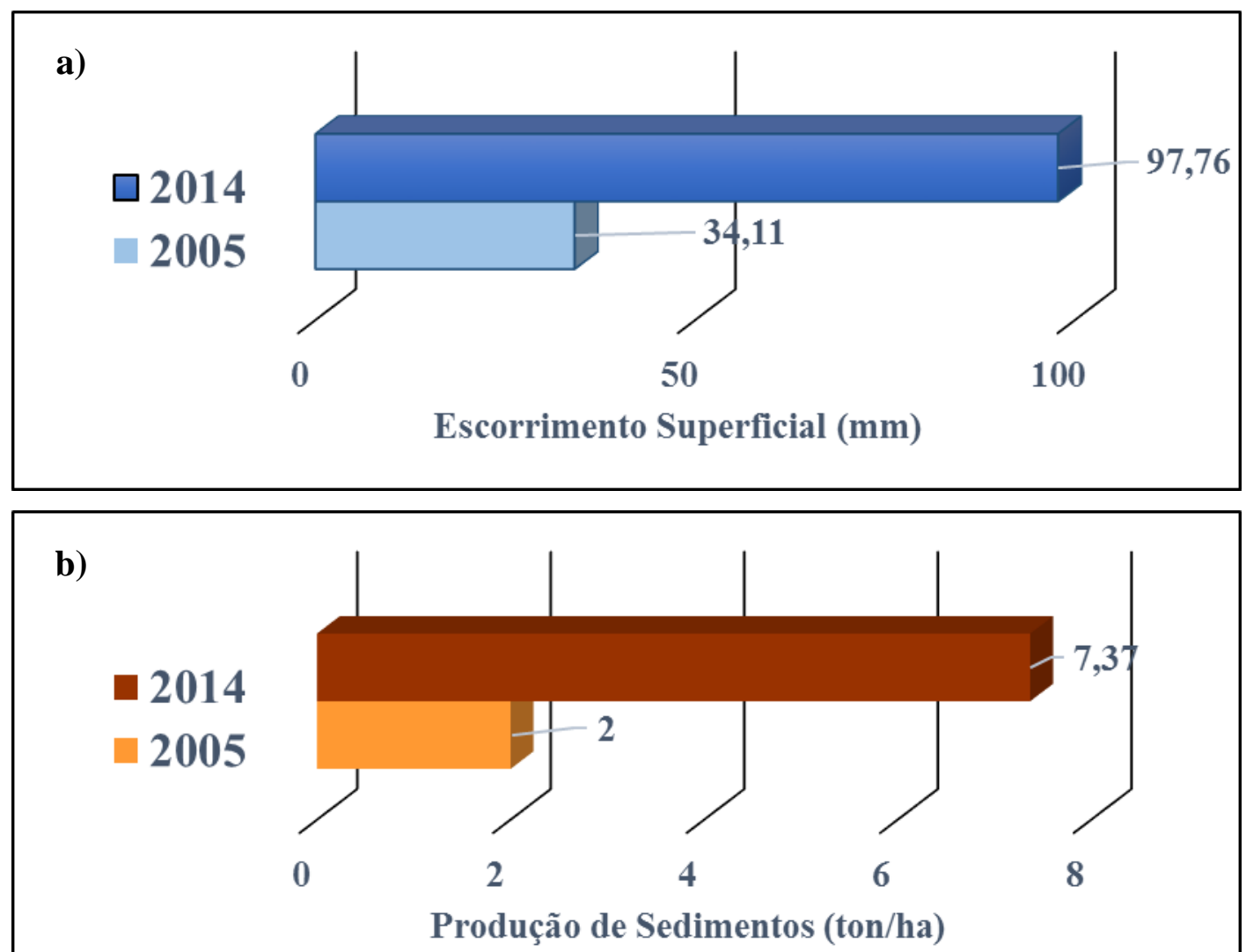

Figura 36. a) comparação entre as produções de escorrimento superficial dos cenários de 2005 e 2014 para a sub-bacia 24.b) comparação entre as produções de sedimentos dos cenários de 2005 e 2014 para a subbacia 24.

Na Figura 36a constatou-se que a substituição de 70,26 ha de áreas de pastagens por cana-de-açúcar no cenário de 2014, resultou em um aumento de $186 \%$ nas taxas de escorrimento superficial, que passou de 34,11 em 2005 para 97,76 mm em 2014. Quanto à produção de sedimentos, verifica-se na Figura 36b que houve um significativo aumento nessas taxas de aproximadamente 268,5\%, passando de 2,0 no cenário de 2005 para 7,37 ton.ha ${ }^{-1} \cdot$ ano $^{-1}$ Em relação a sub-bacia 26, a Tabela 12 apresenta as alterações de uso e ocupação ocorridas entre os dois cenários. 
Tabela 12. Mudança de uso e ocupação ocorrida na sub-bacia 26 entre os cenários de 2005 e 2014.

\begin{tabular}{|c|c|c|}
\hline Sub-Bacia & Ano 2005 & Ano 2014 \\
\hline \multicolumn{3}{|l|}{26} \\
\hline Uso e Ocupação do Solo & Cana-de-açúcar: 0 ha & Cana-de-açúcar: 85,77 ha \\
\hline \multirow{3}{*}{$\begin{array}{l}\square \text { Cana } \\
\square \text { Pasto } \\
\square \text { Vegetação }\end{array}$} & Pastagem: 93,26 ha & Pastagem: 7,22 ha \\
\hline & Vegetação: 6,85 ha & Vegetação: 7,12 ha \\
\hline & \multicolumn{2}{|c|}{ Área total: $100,11 \mathrm{ha}$} \\
\hline
\end{tabular}

Nota-se na Tabela 12 que o acréscimo de área com o cultivo de cana-de-açúcar no cenário de 2014 foi de 85,77 ha, valor equivalente a 85\% da área da sub-bacia. Este acréscimo ocorreu sobre as áreas de pastagem, que no cenário de 2005 ocupava aproximadamente, 93\% da área da sub-bacia, valor que para o cenário de 2014 foi reduzido a 7\%. Verificou-se que além do cultivo da cana-de-açúcar, a área de pastagem também cedeu lugar a vegetação, que registrou um aumento de 0,27 ha. $\mathrm{O}$ comparativo entre as taxas de escorrimento superficial e a produção de sedimento entre os dois cenários da sub-bacia 26, podem ser visualizados na Figura 37.

a)

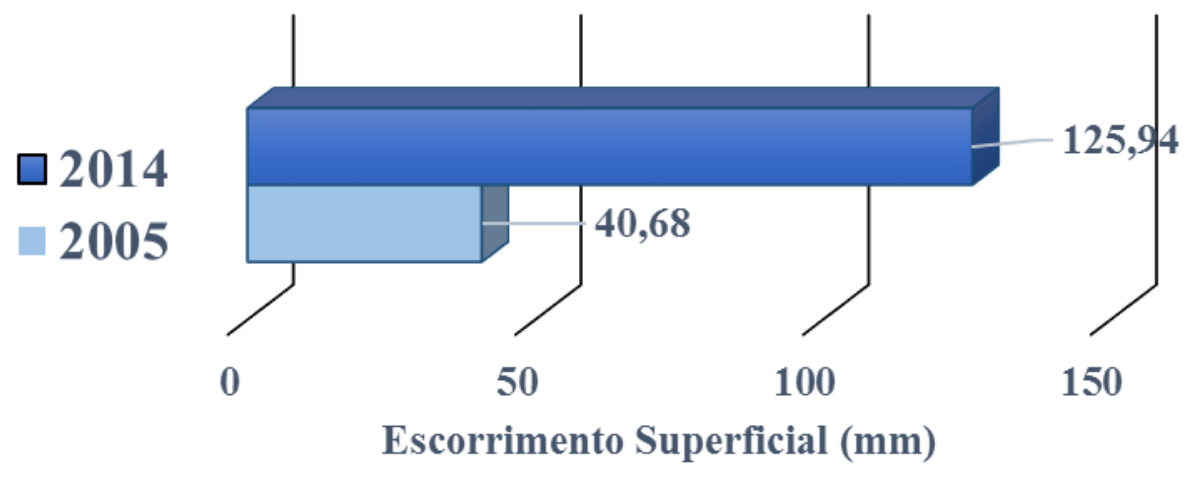




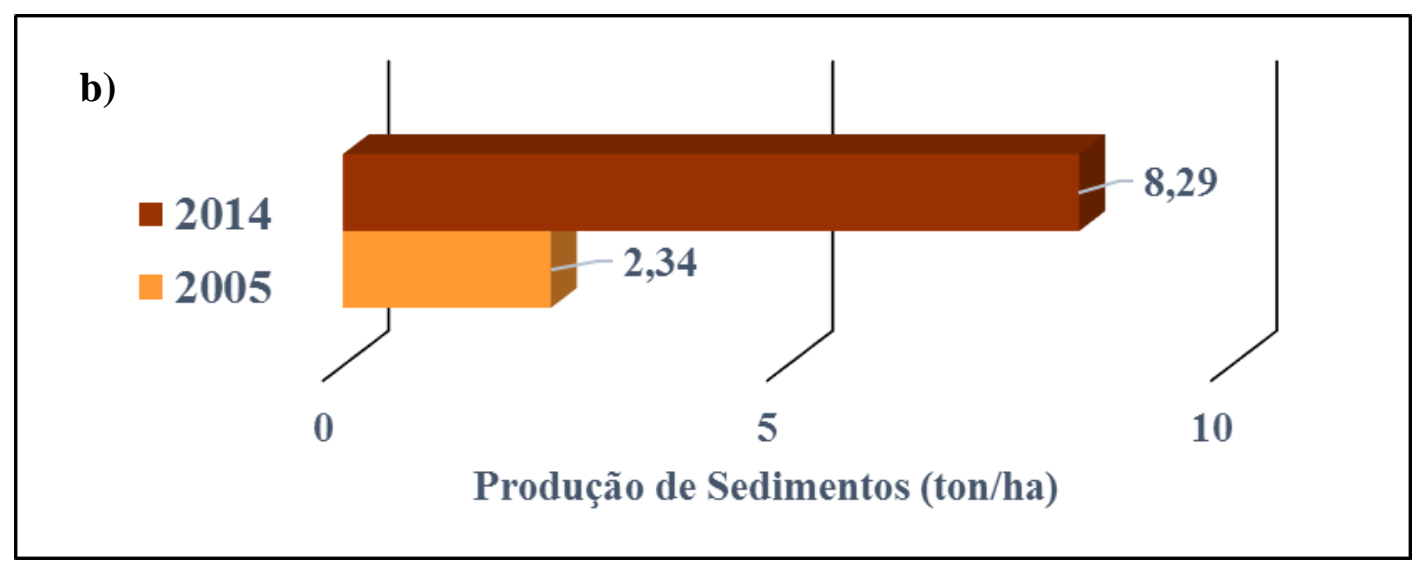

Figura 37. a) comparação entre as produções de escorrimento superficial dos cenários de 2005 e 2014 para a sub-bacia 26. b) comparação entre as produções de sedimentos dos cenários de 2005 e 2014 para a sub-bacia 26.

Analisando a Figura 37a, observa-se que a expansão do cultivo da cana-de-açúcar ocorrida na sub-bacia, resultou em um expressivo aumento de aproximadamente $209 \%$ no valor de escorrimento superficial do cenário de 2005 (40,68 mm) para o cenário de 2014 (125,94 mm). De forma análoga, a produção de sedimentos (Figura 37b) apresentou um significativo aumento, que aproximou-se de $254 \%$, passando de 2,34 ton.ha ${ }^{-1}$.ano ${ }^{-1}$ no cenário de 2005 para 8,29 ton.ha ${ }^{-1}$.ano ${ }^{-1}$ no cenário de 2014. Diante dos resultados apresentados pelas sub-bacias 24 e 26, confirmou-se a influência que o cultivo da cana-de-açúcar exerce sobre as taxas de escorrimento e de produção de sedimentos, em relação às áreas de pastagem.

\subsubsection{Avaliação das estimativas de escorrimento superficial e produção de sedimentos}

Em virtude da inexistência de dados monitorados de produção de sedimentos e escorrimento superficial na microbacia, as estimativas simuladas para os cenários foram avaliadas mediante a comparação com valores de referência encontrados na literatura. Devido ao processo de definição das sub-bacias ter buscado uma certa proporcionalidade entre suas áreas, verificou-se que, tal definição não resultou em combinações exclusivas de tipos de usos, que permitissem fornecer estimativas para cada uso específico. Neste contexto, visando obter valores médios de produção de sedimentos para os usos predominantes dos cenários de 
2005 (pastagem) e 2014 (cana-de-açúcar), realizou-se uma análise prévia a fim de identificar sub-bacias que apresentassem a conversão quase integral entre os usos supracitados.

Após está análise, constatou-se que apenas as sub-bacias 24 e 26 se aproximaram da condição ideal para extrair valores médios de produção entre os dois tipos de uso.

Desta forma, baseado nas taxas obtidas para estas duas sub-bacias, estimou-se a produção média de sedimentos para os dois tipos de usos, sendo estas apresentadas na Tabela 13.

Tabela 13. Estimativa da produção média de sedimentos para dois tipos de usos.

\begin{tabular}{|cc}
\hline Tipos de uso & Produção média de sedimentos (ton./ha ${ }^{-\mathbf{1}}$.ano) \\
\hline Pastagem & 2,17 \\
\hline Cana-de-açúcar & 7,83 \\
\hline
\end{tabular}

Observa-se na Tabela 13 que a produção média de sedimento para o uso pastagem foi de 2,17 ton. ha ${ }^{-1} \cdot$ ano $^{-1}$ e para cana-de-açúcar 7,83 ton.ha- ${ }^{-1} \cdot$ ano $^{-1}$. Nota-se uma diferença de aproximadamente 3,5 vezes da média obtida para a cana-de-açúcar em relação ao valor do pasto.

Youlton, (2013) estudou o impacto na erosão dos solos pela conversão de pastagem em cana-de-açúcar em uma fazenda com solo Neossolo Quartzarênico, situada em Itirapina-SP. Utilizando parcelas de escoamento, no primeiro ano do estudo, verificou-se taxas de escorrimento superficial para pastagem e cana-de-açúcar de respectivamente, 40,5 e $56,1 \mathrm{~mm}$. No segundo ano do experimento, as taxas foram menores, apresentando $30,4 \mathrm{~mm}$ para a pastagem e 18,6 mm para o cultivo da cana-de-açúcar. Segundo o autor, a redução do escorrimento no cultivo cana-de-açúcar, deve-se sobretudo à palha (resíduo da colheita sem queima) deixada sobre o solo. A palha atua como barreira, reduzindo a velocidade e o volume do escorrimento, além de favorecer a infiltração no solo.

Em comparação com os dados simulados obtidos pela média dos valores apresentados pelas sub-bacias 24 e 26, verifica-se que as produções de escorrimento são praticamente iguais. O valor simulado $37,39 \mathrm{~mm}$ está subestimado em apenas $3,11 \mathrm{~mm}$ em relação ao valor 
encontrado para o primeiro ano do experimento de 40,5 $\mathrm{mm}$. No entanto, se comparado com o valor obtido no segundo ano do experimento de $30,4 \mathrm{~mm}$, o valor simulado apresenta-se superestimado em 6,9 mm. Segundo Youlton (2013), a diferença entre os valores de escorrimento do primeiro para o segundo ano pode ser atribuída ao preparo empregado no primeiro ano do plantio. Para as taxas de escorrimento da cana-de-açúcar, o valor obtido pela média de produção das sub-bacias 24 e 26, de $111 \mathrm{~mm}$ apresenta-se superestimado em 54,9 mm se comparado ao primeiro ano do experimento e em $92,4 \mathrm{~mm}$ no segundo ano. A diferença entre a taxa simulada e os valores obtidos pelo experimento, pode ser explicada pela presença da palha da cana no solo, fator que não foi considerado na modelagem, devido à ausência de dados parametrizados.

Em relação a produção de sedimentos, verifica-se que para o uso pastagem o valor médio de 2,17 ton.ha ${ }^{-1}$.ano ${ }^{-1}$ está superestimado em 1,91 ton.ha ${ }^{-1} \cdot$ ano $^{-1}$, se comparado ao valor de 0,26 ton.ha ${ }^{-1} \cdot$ ano $^{-1}$ obtido pelo autor. Para a cana-de-açúcar o valor médio simulado de 7,83 ton.ha ${ }^{-1} \cdot$ ano $^{-1}$ apresenta-se superestimado em 5,51 ton.hat ${ }^{-1} \cdot$ ano $^{-1}$, para o valor obtido no primeiro ano de experimento 2,32 ton.ha ${ }^{-1} \cdot$ ano $^{-1}$, com cana-planta. Se comparado com a produção de sedimento obtida no segundo ano de 0,47 ton. ha $^{-1} \cdot$ ano $^{-1}$ com a cana-soca, verifica-se que o valor médio está superestimado em 7,36 ton. ha ${ }^{-1}$.ano ${ }^{-1}$. Nota-se uma diferença significativa entre as taxas, que pode ser explicada pelo mesmo fator que justifica a diferença entre as taxas de escorrimento, referente a palha da cana no solo.

O estudo de Martins Filho et al. (2009) corrobora o argumento da influência da presença da palha sobre o solo. Avaliando as perdas de solos e de nutrientes em um Argissolo no município de Catanduva-SP, os autores constataram a partir de experimentos com parcelas, que a perda de solo na cana-de-açúcar sem a cobertura da palha é de 5,81 ton. $\mathrm{ha}^{-1} \cdot \mathrm{ano}^{-1}$, com $50 \%$ de cobertura, 1,93 ton.ha ${ }^{1}$.ano ${ }^{-1}$ e com $100 \%, 0,77$ ton. ha ${ }^{-1}$.ano ${ }^{-1}$. Sousa, Martins Filho e Matias (2012) também constataram uma redução nas taxas de erosão com o 
solo revestido com a palha, no cultivo de cana-de-açúcar. O estudo foi realizado em GuaribaSP, utilizando parcelas em um Latossolo, no qual verificou-se que as maiores taxas de erosão ocorreram em áreas com maior declividade e sem a cobertura da palha, registrando uma perda média de 0,096 ton. ha ${ }^{-1}$.ano ${ }^{-1}$. O menor valor foi obtido nas condições de menor declividade e com $100 \%$ de cobertura da palha, com uma perda de 0,001 ton. ha ${ }^{-1} \cdot$ ano $^{-1}$.

Bertoni e Lombardi Neto (1999), estimaram a perda média de solo para várias culturas no estado de São Paulo, sendo que para a pastagem estimou-se 0,4 ton.ha ${ }^{-1} \cdot$ ano $^{-1}$ e para o cultivo da cana-de-açúcar 12,4 ton.ha ${ }^{-1} \cdot$ ano $^{-1}$. Comparando os valores obtidos pela simulação com as estimativas dos autores, constata-se que os valores simulados estão superestimados em 0,97 ton./ha para o uso pastagem e subestimado em 4,57 ton./ha para o cultivo de cana-de-açúcar.

Silva et al. (2010) aplicaram os softwares IDRISI e USLE 2D para estimar as perdas de solo na Fazenda Canchim da Embrapa Pecuária Sudeste, localizada no município de São Carlos-SP. Dentre as estimativas para os diferentes tipos de usos, verificaram para a pastagem e o cultivo de cana-de-açúcar uma perda de respectivamente, 3,86 e 32,5 ton.ha ${ }^{-1} \cdot$ ano $^{-1}$. Nota-se que estes valores estão superestimados em relação aos valores simulados neste estudo. O mesmo comportamento é verificado quando comparado o valor médio simulado da perda de solo para cana-de-açúcar com o valor obtido para a cultura em um estudo realizado por Sparovek e Schnug (2001), utilizando o modelo Water Erosion Prediction Project - WEPP na bacia do Ceveiro, Piracicaba-SP, cujo o valor estimado foi de 31 ton. ha ${ }^{-1}$.ano ${ }^{-1}$. Já comparando o valor médio de perda simulado para cana com o valor obtido por Andrade et al. (2011) utilizando a Equação Universal de Perda de Solos (USLE) em um Argissolo no município de Catanduva-SP, verifica-se pouca diferença entre as taxas, sendo 7,83 ton. ha ${ }^{-1}$.ano ${ }^{-1}$ para o simulado e 9,64 ton. ha ${ }^{-1} \cdot$ ano $^{-1}$ pelo autores. 
Drugowich, Savastano e Lima Savastano (2009) constataram a partir de um estudo sobre erosão em pastagens no Estado de São Paulo, que a pecuária leiteira e mista ocupa 3.688.072 hectares de áreas de pastagem no estado. Segundo os autores, em $20 \%$ da área apresenta alto nível de degradação, com a presença de sulcos profundos e voçoroca. Em $60 \%$ da área verificou-se um nível de degradação menor, apresentando erosão laminar, e apenas em 20\% são manejadas de forma adequada, registrando alta produção e baixas taxas de erosão. Os autores estimaram a perda de solo utilizando o modelo USLE, e constaram valores de 10 ton. ha ${ }^{-1} \cdot$ ano $^{-1}$ para pastagens degradadas e 0,19 ton. ha ${ }^{-1} \cdot$ ano $^{-1}$ nas áreas de pastagem bem manejadas. Observa-se que o valor simulado de 2,17 ton. ha $^{-1} \cdot$ ano $^{-1}$ para pastagem está subestimado em relação a estimativa para áreas degradadas e superestimada para as áreas com menor degradação. Baseado nestas estimativas e comparando-as com os valores médios de perda de solo para pastagem e cana-de-açúcar simulados, verifica-se que o potencial de perda de solo em áreas de pastagem degradada pode ser maior do que em áreas com cana-de-açúcar. No entanto, em comparação com as taxas registradas em pasto com manejo adequado, a perda de solo em áreas de cana-de-açúcar é maior.

Silva et al. (2005) estimaram a perda de solo para pastagem, aplicando o modelo USLE em uma microbacia no município de Cunha-SP, e verificaram uma perda máxima de 28 ton. ha $^{-1} \cdot$ ano $^{-1}$ sob Latossolo, valor bem superior ao simulado.

As diferenças das estimativas de perda de solo entre as apresentadas nos trabalhos citados anteriormente, e os valores simulados por este estudo, provavelmente estejam relacionadas as diferentes metodologias aplicadas na obtenção destes valores, além da diferença entre características como: tipo de solo, relevo e condições climáticas.

Machado e Vetorazzi (2003) estimaram a produção de sedimentos utilizando o Modelo SWAT na microbacia do Ribeirão do Marins localizada em Piracicaba - SP. A partir do modelo calibrado os autores constataram que as maiores taxas de produção ocorreram em 
áreas com o cultivo de cana-de-açúcar que variaram de 6,3 a 11,3 ton. ha ${ }^{-1}$.ano ${ }^{-1}$. Lessa et al. (2013), constataram que as taxas das sub-bacias ocupadas predominantemente por cana-de-açúcar variaram de 5 a 10 ton. ha $^{-1}$.ano ${ }^{-1}$ em uma aplicação do SWAT na parte inicial da Bacia do Rio Pardo, (SP). Em comparação com trabalhos realizados com SWAT, que efetuaram a calibração para sedimentos, verifica-se uma boa correspondência entre os valores estimados para o cultivo de cana-de-açúcar. Tal correspondência indica que os valores obtidos neste trabalho, demonstram-se satisfatórios para estimativas de produção de sedimentos. 


\section{CONCLUSÕES}

O presente estudo buscou avaliar a influência da expansão do cultivo da cana-de-açúcar sobre os aspectos hidrossedimentológicos em uma microbacia hidrográfica que apresentou significativo aumento desta cultura.

A avaliação da dinâmica hidrossedimentológica da microbacia estudada foi realizada por meio do Modelo SWAT, o qual permitiu simular as vazões médias e gerar estimativas de produção de escorrimento superficial e da produção de sedimentos. Após realizar a simulação que abrangeu o período de 2004 a 2010, verificou-se que inicialmente os valores para a vazão média apresentaram comportamento superestimado no período chuvoso e subestimado na estiagem. Este comportamento refletiu negativamente nos coeficientes de desempenho estatísticos utilizados ( $\mathrm{R}^{2}$, NSE e PBIAS), que se mostraram insatisfatórios, de modo a direcionar a modelagem aos procedimentos de ajustes.

Nesta etapa realizou-se uma análise de sensibilidade na qual verificou-se alta sensibilidade de variáveis relacionadas a água subterrânea e de propriedades físicas dos solos. O ajuste a estas variáveis melhorou significativamente o desempenho da modelagem em estimar os valores médios da vazão para a microbacia. Tal melhora pôde ser notada nos coeficientes de desempenho, que de acordo com valores de referência, passaram de insatisfatório (quando não aplicado os procedimentos de calibração), para muito bom com o modelo calibrado.

A consistência da calibração foi verificada, simulando as vazões médias para um novo período (2011 a 2014) e comparando-as com os dados observados correspondentes. Embora os coeficientes de desempenho tenham apresentado valores menores, comparando-se com os da modelagem calibrada, ainda assim conseguiram se enquadrar como sendo muito bom, perante aos valores de referência. 
Com o modelo calibrado foram estimados os valores de escorrimento superficial e produção de sedimentos para os cenários de 2005 e 2014. Para ambos os cenários a produção de escorrimento foi maior nas sub-bacias com a presença do cultivo de cana-de-açúcar, fato que pode ser atribuído ao elevado valor de $\mathrm{CN}$ apresentado por esse tipo de uso.

As maiores taxas de produção foram verificadas nos tipos de uso com elevado fator C (cobertura do solo) e nos tipos de solos que apresentaram o maior valor do fator $\mathrm{K}$ (erodibilidade).

A partir da metodologia empregada no estudo, pôde-se concluir que a substituição de grandes áreas de pastagem (cenário 2005) pelo cultivo de cana-de-açúcar (cenário 2014), resultou em um considerável aumento nas taxas de escorrimento superficial e produção de sedimentos na microbacia.

Conclui-se também que em relação ao limite de tolerância de perdas de solos, as taxas de produção de sedimentos para o cenário de 2005 são consideradas baixas e para o cenário de 2014 como médias.

Embora a aplicação do SWAT ter permitido estimar as vazões médias, taxas de produção de sedimentos e escorrimento superficial para os cenários propostos, ressalta-se que o mesmo não é capaz de substituir a rede de monitoramento hidrossedimentológico. Desta forma, o SWAT surge como uma ferramenta para obter dados hidrossedimentológicos, auxiliando no planejamento e gestão dos recursos hídricos em bacias onde o monitoramento é precário ou inexistente. Além disso, o Modelo pode complementar informações à rede de monitoramento, tais como: identificar e mapear regiões mais propensas à erosão, permitindo direcionar ações preventivas e corretivas com maior eficiência. 


\section{REFERÊNCIAS BIBLIOGRÁFICAS}

ABBASPOUR, K.C., JOHNSON, C., VAN GENUCHTEN, M.T. Estimating uncertain flow and transport parameters using a sequential uncertainty fitting procedure. Vadose Zone Journal 3, 1340-1352, 2004.

ABBASPOUR, K. C. User Manual for SWAT-CUP, SWAT Calibration and Uncertainty Analysis Programs, Swiss Federal Institute of Aquatic Science and Technology, EAWAG, Dubendorf, Switzer- “ land, 2007.

ABBASPOUR, K.C. SWAT-CUP2: SWAT Calibration and Uncertainty Programs - A User Manual. Department of Systems Analysis, Integrated Assessment and Modelling (SIAM), Eawag, Swiss Federal Institute of Aquatic Science and Technology, Duebendorf, Switzerland, p.95, 2008.

ABBASPOUR, K.C. SWAT-CUP 2012: SWAT Calibration and Uncertainty Programs A User Manual. 2012.

ANDRADE, M.A.; MELLO, C.R. E BESKOW, S. Simulação hidrológica em uma bacia hidrográfica representativa dos Latossolos na região Alto Rio Grande, MG. Revista Brasileira de Engenharia Agrícola e Ambiental, v.17, n.1, p.69-76, 2013.

ANDRADE, N. S. F.; MARTINS FILHO, M. V.; TORRES, J. L. R.; PEREIRA, G. T.; MARQUES JÚNIOR, J. Impacto técnico e econômico das perdas de solo e nutrientes por erosão no cultivo da cana-de-açúcar. Engenharia Agrícola, Jaboticabal, v. 31, n. 3; p. 539$550,2011$.

ANDRADE, M.C. Estado, capital e industrialização do Nordeste. Rio de Janeiro: Editora Zahar, 100-101p. 1981.

ADRIOLO, M. V.; SANTOS. L.; GIBERTONI, R. C.; CAMARGO, A. S. G. Calibração do modelo SWAT para a produção e transporte de sedimentos. In SIMPÓSIO SOBRE PEQUENAS E MÉDIAS CENTRAIS HIDRELÉTRICAS, 6. 2008. Belo Horizonte. Anais, Belo Horizonte: Comitê Brasileiro de Barragens. V. 1, p. 1-17. 2008.

ANFAVEA. Planilha: Anuário da Indústria Automobilística Brasileira. 2013. Disponível em http://www.anfavea.com.br/tabelas2013.html. Acesso em 13 de outubro de 2014. 
ARAGÃO, R.; CRUZ, M.A.S.; AMORIM, J.R.A.; MENDONÇA, L.C.; FIGUEIREDO, E.E.; SRINIVASAN, V.S. Análise de sensibilidade dos parâmetros do modelo SWAT e simulação dos processos hidrossedimentológicos em uma bacia no agreste nordestino. Revista Brasileira de Ciência do Solo, 37:1091-1102. 2013.

ARBEX, M. A.; BÖHM, G.M.; SALDIVA, P.H.; CONCEIÇÃO, G.M.; POPE, A.C.; BRAGA, A.L. Assessment of the effects of sugar cane plantation burning on daily counts of inhalation therapy. J. Air Waste Management Assoc., v.50, n.10, p.1745-9, 2000.

ARNOLD, J. G.; WILLIAMS. J. R. Validation of SWRRB: Simulator for water resources in rural basins. J. Water Resour. Plan. Manage. ASCE 113(2): 243-256. 1987.

ARNOLD, J. G.; MORIASI, D. N.; GASSMAN, P. W.; ABBASPOUR, K. C.; WHITE, M. J.; SRINIVASAN, R.; SANTHI, C.; HARMEL, R. D.; VAN GRIENSVEN, A.; VAN LIEW, M. W.; KANNAN, N.; JHA, M. K. SWAT: Model Use, Calibration, and Validation. American Society of Agricultural and Biological Engineers, Transactions of the ASABE, v. 55(4), p. 1491-1508. 2012.

ARNOLD, J. G.; SRINIVASAN, R.; MUTTIAH, R. S.; WILLIAMNS, J. R. Large-area hydrologic modeling and assessment: Part I. Model development J. American Water Resour. Assoc. 34(1): 73-89. 1998.

ARROIO JUNIOR, P.P. Avaliação da produção e transporte de sedimentos na bacia hidrográfica do Rio Itaqueri, municípios de Itirapina e Brotas - SP. 112 p. Dissertações (mestrado em Ciências da Engenharia Ambiental) - Escola de Engenharia de São Carlos, Universidade de São Paulo, São Carlos, 2013.

ATHENAS CONSULTORIA AGRÍCOLA E LABORATÓRIO Jaboticabal - SP, Análises químicas e físicas e mapeamento microbacia do Córrego Cana do Reino, Votuporanga SP. 2014.

BABEL, M. S.; SHRESTHA, B.; PERRET; S. R. Hydrological impact of biofuel production: A case study of the Khlong Phlo Watershed in Thailand. M.S. Agricultural Water Management 101 8-26, 2011.

BALDISSERA, G. C. Aplicabilidade do modelo de simulação hidrológica SWAT (Soil and Water Assessment Tool), para a bacia hidrográfica do Rio Cuiabá/MT. Cuiabá - 
MT. Dissertação (mestrado em Física e Meio Ambiente). Universidade Federal do Mato Grosso, 2005.

BALTOKOSKI, V.; TAVARES, M. H. F.; MACHADO, R. E.; OLIVEIRA, M. P.. Calibração de modelo para a simulação de vazão e de fósforo total nas sub-bacias dos rios Conrado e Pinheiro - Pato Branco (PR). Revista Brasileira de solos, v,34, p.253-261. 2010.

BARRoS, G. S. C.; MORAES, M. A. F. D. A Desregulamentação do Setor Sucroalcooleiro. Revista de Economia Política, vol. 22, nº 2 (86), abril-junho/2002.

BERTONI, J.; LOMBARDI NETO, F. Conservação do solo. 2.ed. São Paulo, Ícone, 355p. 1999.

BIESBROUCK, B.; WYSEURE, G.; VAN ORSCHOVEN, J.; FEYEN, J. AVSWAT 2000. Katholieke Unisersiteit Leuven (K.U.Leuven), Belgium. p. 199, 2002.

BINI, D. L. C. Mudanças históricas e implicações sócio-espaciais na composição das atividades agropecuárias hegemônicas na região de Araçatuba (SP). São Paulo: Dissertação de Mestrado (DG/FFLCH-USP), 2009.

BOOPATHY, R.; ASRABADI, B. R.; FERGUSON, T. G. Sugar cane (Saccharum officinarum L) burning and asthma in Southeast Louisiana, USA. Bull Envir Contam Toxicol., v.68, n.2, p.173-9, 2002.

BORDAS, M. P.; SEMMELMANN, F. R. Elementos de Engenharia de Sedimentos (Capítulo 24): In: Hidrologia/ Ciência e Aplicação, $2^{\circ}$ ed , $2^{\circ}$ reimpr. ed. Universidade / UFRGS ABRH, Porto Alegre: 943 p. 2001.

BRASIL. Resolução CONAMA n. ${ }^{\circ}$ 003/1990. Estabelece Padrões de Qualidade do Ar e Amplia o Número de Poluentes Atmosféricos Passíveis de Monitoramento e Controle. Coletânea de Legislação Ambiental. 1990. Disponível em: http: www.mma.gov.br/port/conama/res/res90/res0390.html. Acesso em 05/03/2014.

BRASIL. Casa Civil. DECRETO-LEI No 9.827, DE 10 DE SETEMBRO DE 1946. Disponível em: <http://www.planalto.gov.br/ccivil_03/decreto-lei/del9827.htm> Acesso em: 11 fev. 2014. 
BRAY S. C.; FERREIRA, E. R. As agro-indústrias e a formação do setor canavieiro de Araras. Rio Claro: Boletim de Geografia Teorética, 13(25) pp. 57-68, 1983.

BRAY, S. C. A cultura da cana-de-açúcar no vale do Paranapanema - um estudo de geografia agrária. São Paulo, Tese de Doutorado - USP, 1980.

BRITTO, F. B.; VASCO, N. A.; PEREIRA, A. P. S.; MELlO, J. R. A. V.; NOGUEIRA, L. C. Avaliação da contaminação por pesticida da água do rio Poxim usada para abastecimento público de Aracajú, Sergipe. In: Encontro de Recursos Hídricos em Sergipe, 6, Aracaju. 2011.

CAN, T.; XIAOLING, C.; JIANZHONG, L.; GASSMAN, P.; SABINE, S.; PEREZ J. M. S.. Using SWAT model to assess impacts of different land use scenarios on water budget of Fuhe River, China. International Journal of Agricultural \& Biological Engineering.v8. 2015.

CARVAlHO, N.O. Hidrossedimentologia Prática. Rio de Janeiro: Interciência. 599 p. 2008.

CARVALHO, A. Experiencia de la Utilizacion de Alcohol Carburante en el Brasil, Instituto de Economia Energetica, Bariloche, novembro, 1993.

CASALECCHI, J. E. Da companhia industrial, agrícola e pastoril D’Oeste de São Paulo à Cambuhy coffee and cotton estates: 1912-1933. Contribuição ao estudo da presença inglesa na estrutura agrária do Estado de São Paulo. Tese (Doutorado). FFCLA, Araraquara, 1973.

CELESTE, A. B.; CHAVES, V. S. Avaliação de Algoritmos de Otimização e Funções Objetivo para Calibração Automática do Modelo Chuva-Vazão Tank Model. Ciência e Natura, Santa Maria, Revista do Centro de Ciências Naturais e Exatas - UFSM. v. 36 n. 3, p. 527-537, set - dez. 2014.

CERQUEIRA LEITE, R. C.; LEAL, M. R. L. V.; CORTEZA, L. A. B.; GRIFFIN, W. M.; Scandiffio, M. I. G. Can Brazil replace 5\% of the 2025 gasoline world demand with ethanol?. Energy. v. 34, n.5, p. 655-661, May 2009. 
COElHO, S. T.; GUARDABASSI, P.M.; LORA, B. A.; MONTEIRO, M. B. C. A. C.; GORREN, R. Sustentabilidade da expansão da cultura canavieira. Cadernos Técnicos da Associação Nacional de Transportes Públicos, v.6, p.13, 2007.

CORBI, J. J.; STRIXINO, S. T.; SANTOS, A.; GRANDE, M. DEL. Diagnóstico ambiental de metais e organoclorados em córregos adjacentes às áreas de cultivo de cana-deaçúcar, Estado de São Paulo, Brasil. Química Nova, v.29, p.61-65, 2006.

CORREIA, E. "Mercado de gasolina: impacto da introdução dos veículos flex-fuel”, Resumo Estratégico Petrobras, Rio de Janeiro, julho, 2005.

CORREIA, E. "Proálcool - do sucesso à polêmica", Revista Agroanalysis, vol.16-nº, pp. 12-16, Rio de Janeiro, agosto, 1996.

CORREIA, E. "The Reemergence of Ethanol Fuel in Brazil", Oxford Energy Forum, Oxford, fevereiro, 2007.

CORTEZ, L.A.B. Bioetanol de cana-de-açúcar P\&D para produtividade e sustentabilidade. São Paulo: Editora: Edgard Blucher Ltda. 2010.

COSTA, A. C. P. Emissões de poluentes atmosféricos no setor sucroalcooleiro - position paper painel III. Workshop aspectos ambientais da cadeia do etanol de cana-de-açúcar. Projeto Diretrizes de Políticas Públicas para a agroindústria canavieira do Estado de São Paulo, Programa de Pesquisa de Políticas Públicas - PPPP, São Paulo, Abril 2008.

DAEE, Departamento de Água e Energia Elétrica, Estado de São Paulo, Dados Hidrológicos. Disponível em: < http://www.sigrh.sp.gov.br/cgi-bin/bdhm.exe/flu?lig=podfp> Acesso em: 23 Nov. 2013.

DI LUZIO, M.; SRINIVASAN, R.; ARNOLD, J. ArcView interface for SWAT2000 User's Guide. Temple, Blackland Research Center, Texas Agricultural Experiment Station. 395p, 2001.

DRUGOWICH, M. I.; SAVASTANO, S.; SAVASTANO LIMA, S. A. A. Erosão em pastagens sob pecuária leiteira e mista no Estado de São Paulo. 2009 Disponível em http://www.cati.sp.gov.br/ projeto lupa, acesso em 25 de junho de 2014. 
EMBRAPA - Serviço Nacional de Levantamento e Conservação de Solos (Rio de Janeiro, RJ). Súmula da 10. Reunião Técnica de Levantamento de Solos. Rio de Janeiro: 83p. (Embrapa-SNLCS. Micelânea, 1), 1979.

EMBRAPA. Centro Nacional de Pesquisa de Solos (Rio de Janeiro, RJ). Manual de métodos de análise de solo. 2.ed.rev.atual. Rio de Janeiro,. 212p. 1997.

EMBRAPA. Centro Nacional de Pesquisa de Solos. Procedimentos normativos de levantamentos pedológicos. Brasília: Embrapa - SPI, 116p. 1995.

EMPLASA- Projeto Mapeia São Paulo, Empresa Paulista de Planejamento Metropolitano S/A. 2013.

ESRI, ArcView 9.3 Disponível em: <http://www.esri.com/> 2014.

FANG, X.; REN, L.; LI, Q.; ZHU, Q.; SHI, P.; ZHU, Y. Hydrologic Response to Land Use and Land Cover Changes within the Context of Catchment-Scale Spatial Information. J. Hydrol. Eng., v. 18, n. 11, 1539-1548, 2013.

FAO. Food and Agriculture Organization. Countries by Comodity-sugarcane, 2012.

FAUSTO, B. História do Brasil. São Paulo. Edusp, 660 p. 2006.

FERREIRA, E. R.; ALVES, F. Organização espacial da cana-de-açúcar no Estado de São Paulo: uma análise evolutiva. p.1-18. V Encontro de Grupos de Pesquisa "Agricultura, desenvolvimento regional e transformações socioespaciais", Santa Maria-RS, 2009.

FIGUEIREDO, P. Breve história da cana-de-açúcar e o papel do Instituto Agronômico no seu estabelecimento no Brasil. In: DINARDO-MIRANDA, L. L.; VASCONCELOS, A. C. M. de; ANDRADE LANDELL, M. G. de. Cana-de-açúcar. Campinas: Instituto Agronômico, p. 31-45. 2008.

FLANAGAN, D.C.; NEARING, M.A. USDA-Water Erosion Prediction Project: Hillslope Profile and Watershed Model Documentation. NSERL Report No. 10. USDA-ARS National Soil Erosion Research Laboratory. West Lafayette, Indiana. 1995.

FREITAS, L.C.; KANEKO, S. Ethanol demand under the flex-fuel technology regime in Brasil. Energy Economics, v.33, n. 6, p. 1146-1154, 2011. 
FUKUNAGA, D. C; CECÍLIO, R. A; ZANETTI, S. S; OLIVEIRA, L. T; COIADO, M.A.C. Application of the SWAT hydrologic model to a tropical Watershed at Brasil. Catena, v.125, p.206-213, 2015.

GALHARTE, C.A.; VILLELA, J.M.; CRESTANA, S. Estimativa da produção de sedimentos em função da mudança de uso e cobertura do solo. Revista Brasileira de Engenharia Agrícola e Ambiental, v.18, n.2, p.194-201, 2014.

GALLARDO, A. L. C. F.; BOND, A. Capturing the implications of land use change in Brazil through environmental assessment: Time for a strategic approach?. Environmental Impact Assessment Review, V. 31, n. 3, p. 261-270, April 2011.

GARbiate, M.V.; VitorinO, A. C. T.; TOMASINI, B. A.; BERGAMiN, A. C.; PANACHUKI, E. Erosão entre sulcos em área cultivada com cana crua e queimada sob colheita manual e mecanizada. Revista Brasileira de Ciência do Solo, v.35, p.2145-2155, 2011.

GARBOSSA, L. H. P. VASCONCELOS, L. R. C.; LAPA K. R.; BLAINSKI, E.; PINHEIRO, A. The use and results of the Soil and Water Assessment Tool in Brazil: A review from 341999 until 2010. In: 2011 International SWAT Conference \& Workshops, Toledo Espanha. p. 1-27. , 2011.

GASSMAN, P.W.; REYES, M.; GREEN, C. H.; ARNOLD, J. G. The Soil and water Assessment Tool: Historical development, applications, and future research directions. Transactions of the American Society of Agricultural and Biological Engineers, St. Joseph,v.50, p.1211- 1250, 2007.

GAUDER, M.; GRAEFF-HÖNNINGER, S.; CLAUPEIN, W. The impacto of a growing bioethanol industry on food production in Brazil. Applied Energy, v 88, n. 3, p. 672-679, mar. 2011.

GESSESSE, B.; BEWKET, W.; BRÄUNING, A. Model-based characterization and monitoring of runoff and soil erosion in response to land use/land cover changes in the modjo watershed, ethiopia. Land Degradation \& Development, 2014.

GLEHN, H. C. Uso do solo e biodiversidade. In: Workshop Aspectos Ambientais da Cadeia do Etanol de cana-de-acucar, 2008, São Paulo. Anais 2008. Disponível em: 
<http://www.apta.sp.gov.br/cana/anexos/position_paper_painel2_helena.pdf >. Acesso em: 05 mar. 2014.

GOLDEMBERG, J.; COELHO, S.T.; GUARDABASSI, P. The sustainability of ethanol production from sugarcane. Energy Policy, v. 36, p 2086-2097, 2008.

GUAGNONI W.C., NAKAO S.H., RIBEIRO M. S. Decisões de Investimento e Meio Ambiente no Setor Sucroalcooleiro. In: International Conference of the Iberoamericam Academy of Management, São Paulo, 3, Atas, 2003. Disponível em http://www.fgvsp.br/iberoamerican/Papers/0341_Artigo-decisoes-investimento-ambiental06.pdf.

HOMDEE, T; PONGPUT, K.; KANAE, S. Impacts of land cover changes on hydrologic responses: a case study of Chi River Basin, Thailand. Annual Journal of Hydraulic Engineering, JSCE, v.55, 2011.

HOROWITZ, A. J. An evaluation of sediment rating curves for estimating suspended sediment concentrations for subsequent flux calculations. Hydrol.Process. 17, pp. 33873409, 2003.

IAC, Instituto Agronômico de Campinas. PRADO, H.; JORGE, J.A.; MENK, J.R.F. Levantamento pedológico detalhado e caracterização fisico-hídrica dos solos da Estação Experimental de Agronomia de Votuporanga (SP). Campinas, 24p. (Boletim Científico, 42), 1999.

INPE Instituto Nacional de Pesquisa Espaciais. Projeto Canasat, 2014. Disponível em: <http://www.dsr.inpe.br/laf/canasat/> Acesso em: 25 mar. 2014.

IPT, Instituto de Pesquisas Tecnológicas do Estado de São Paulo. Orientação para o combate à erosão no Estado de São Paulo. - Bacia do Pardo/Grande: São Paulo Convênio IPT/DAEE (Relatório, 28 184), 1990.

IPT, Instituto de Pesquisas Tecnológicas, RELATÓRIO TÉCNICO Nº 87 018-205. Plano de Bacia da Unidade de Gerenciamento de Recursos Hídricos do Rio São José dos Dourados -UGRHI 18. 2008. 
JACOMINI, A. E.; CAMARGO, P. B.; AVELAR, W. E. P.; BONATO, P .S. Assessment of ametryn contamination in river water, river sediment, and mollusk bivalves in São Paulo State, Brazil. Archives of Environmental Contamination and Toxicology, v.60, p.452461, 2011.

KANNAN, N.; WHITE, S.M.; WORRALL, F. WHELAN, M.J. Sensitivity analysis and identification of the best evapotranspiration and runoff options for hydrological modelling in SWAT-2000. Journal of Hydrology, v. 332, p. 456-466. 2007.

KNIGHTON, D. Fluvial forms and process. London: Edward Arnold,. 218 p. 1998.

KNISEL, W.G. CREAMS, a field scale model for chemicals, runoff and erosion from agricultural management systems. USDA Conservation Research Rept. No. 26. 1980;

KUWAJIMA, J. I. Análise do modelo SWAT como ferramenta de prevenção e de estimativa de assoreamento no reservatório do Lobo (Itirapina/Brotas/SP). Dissertação de Mestrado, São Carlos - SP: EESC/USP, 2012.

LAPPONI, J. C. Estatística usando Excel. Rio de Janeiro: Elsevier, 2005.

LELIS, T. A.; CALIJURI, M. L.; SANTIAGO, A. F.; LIMA, D. C.; ROCHA, E. O. Análise de sensibilidade e calibração do modelo SWAT aplicado em bacia hidrográfica 35 da região sudeste do Brasil. Revista Brasileira de Ciência do Solo (Impresso). v. 36. 623-634, 2012.

LESSA, L. G. F; ZIMBACK, C.R.L; LIMA, S.L; MACHADO, R. E. Modelo hidrológico SWAT na determinação das perdas de solo na bacia hidrográfica do rio Pardo Botucatu/SP. Revista Energia na Agricultura, v.28, n.3, p.170-178. 2013.

LIMA, C. G. R.; Souza, A.; Carvalho, M. P.; Costa, N. R.. Estudo da erodibilidade dos solos na bacia hidrográfica do baixo São José dos Dourados.In: XII Congresso Nacional de Meio Ambiente de Poços de Caldas. Poços de Caldas, 2015.

LIMA, J. E. F. W. Modelagem numérica do fluxo da água no solo e do escoamento de base em uma bacia experimental em área agrícola no Cerrado 312 p. Teses de Doutorado, Departamento de Engenharia Civil e Ambiental, Universidade de Brasília, 2010. 
LOPES, F.S.; RIBEIRO, H. Mapeamento de internações hospitalares por problemas respiratórios e possíveis associações à exposição humana aos produtos da queima da palha de cana-de-açúcar no Estado de São Paulo. Revista Brasileira de Epidemiologia, São Paulo, v.9, n.2, p.215-225, 2006.

LOPES, V. L. A numerical model of watershed erosion and sediment yield. Tucson, 148 p. PhD. Dissertation, University of Arizona. (1987).

MACEDO, I. C.; SEABRA, J. E. A.; SILVA, J. E. A. R. Greenhouse gases emissions in the production and use of ethanol from sugarcane in Brazil: The 2005/2006 averages and a prediction for 2020. Biomass and Bioenergy. v. 32, n. 7, p. 582-595, July 2008.

MACHADO, R. E.; VETTORAZZI, C. A. Simulação da produção de sedimentos para a microbacia hidrográfica do Ribeirão dos Marins (SP). Rev. Bras. Ciênc. Solo, v.27, no.4, p.735-741. 2003.

MANNIGEL, A. R.; CARVALHO M. DE P.; MORETI, D.; MEDEIROS, L. R. Fator erodibilidade e tolerância de perda dos solos do Estado de São Paulo. Revista Acta Scientiarum, v.24, n.5, p.1335- 1340. 2002.

MARTINELLI, L.A.; FILOSO, S. Expansion of Sugarcane Ethanol Production in Brazil: Environmental and Social Challenges. Ecological Applications. 18(4): 885-898, 2008.

MARTINS FILHO, M. V.; LICCIOTI, T. T.; PEREIRA, G. T.; MARQUES JÚNIOR, J.; SANCHEZ, R. B. Perdas de solo e nutrientes por erosão num Argissolo com resíduos vegetais de cana-de-açúcar. Engenharia Agrícola, Jaboticabal, v. 29, n.1, p.8-18, 2009.

MEMARIAN, H.; BALASUNDRAM, S. K.; ABBASPOUR, K. C. ; TALIB, J. B.; SUNG, C. T. B. ; SOOD, A. M. SWAT-based Hydrological Modelling of Tropical Land Use Scenarios. Hydrological Sciences Journal, v. 59(10), pp.1808-1829, 2014.

MINELLA, J. P. G.; MERTEN, G. H.; REICHERT, J. M.; SANTOS, D. R. Identificação e implicações para a conservação do solo das fontes de sedimentos em bacias hidrográfica. R. Bras.Ci. Solo, Viçosa - MG, v. 31, n. 6: pp. 1637-1646, 2007.

MINOTTI, R.T. Abordagens qualitativa e quantitativa de micro-bacias hidrográficas e áreas alagáveis de um compartimento do Médio Mogi-Superior/SP. 203 p. Teses de 
Doutorado (doutorado em Ciências da Engenharia Ambiental) - Escola de Engenharia de São Carlos - Universidade de São Paulo, São Carlos, 2006.

MONTGOMERY, D. R.; BUFFINGTON, J. M. Channel-reach morphology in mountain drainage basins, Geological Society of America Bulletin, (109) 5, p. 596-611. 1997.

MOREIRA, E. P.; SZMRECSÁNYI, T. O desenvolvimento da agroindústria canavieira do Brasil desde a Segunda Guerra Mundial. São Paulo, IEA-USP, Revista Estudos Avançados $\mathrm{n}^{\circ} 5$ (11): 57-80, 1991.

MOREIRA, J. R.; GOLDEMBERG, J. The alcohol program. Energy Policy, v.27, n.4,p. 229245, abr.1999.

MOREIRA, I. A. Modelagem hidrológica chuva-vazão com dados de radar e pluviômetros. Dissertação (Mestrado em Engenharia de Recursos Hídricos e Ambientais), Setor de Tecnologia, Universidade Federal do Paraná, 81p. 2005.

MORIASI, D.N; ARNOLD, J. G; VAN LIEW, M. W; BINGER, R. L; HARMEL, R. D; VEITH, T. Model evaluation guidelines for systematic quantification of accuracy in watershed simulations. Trans ASABE 2007; 50(3): 885-900. 2007.

MULLER, D. P. Ensaio d'um quadro estatístico da província de S.Paulo: ordenado pelas leis provinciais de 11 de abril de 1836 e 10 de março de 1837. Imprensa São Paulo: O Estado de São Paulo, 1923.

NATALE NETTO, J. A saga do álcool: fatos e verdades sobre os 100 anos do álcool combustível em nosso país. Osasco, SP, Novo século, 2007.

NASH, J. E.; SUTCLIFFE, J. V.: River flow forecasting through conceptual models, Part I - A discussion of principles, J. Hydrol., 10, 282-290, 1970.

NEITSCH, S. L.; ARNOLD, J. G.; KINIRY, J. R.; SRINIVASAN, R.; Williams, J. R. 2009. Soil and Water Assessment Tool input/output documentation. Version 2009. Disponível em: http://SWAT.tamu.edu/media/99193/SWAT2009-theory-portuguese.pdf acesso em: 05 de junho de 2014. 
NOBERT, J.; JEREMIAH, J. Hydrological Response of Watershed Systems to Land Use/Cover Change. A Case of Wami River Basin. The Open Hydrology Journal, v.6, 7887. 2012.

NYEKO M. Hydrologic Modelling of Data Scarce Basin with SWAT Model: Capabilities and Limitations. Water Resources Management, v.29, n.1, p.81-94, 2015.

OLIVEIRA, A. M. M.; PINTO, S.A.F.; LOMBARDI NETO, F. Caracterização de indicadores da erosão do solo em bacias hidrográficas com o suporte de geotecnologias e modelo predictivo. Estudos Geográficos, Rio Claro, v.5, p.63-86. 2007.

PEREIRA, G.; CARDOZO, F. S.; MORAES, E. C.; PRADO, B. R.; SILVA, G. B. S.; ARAI, E. Estudo preliminar do impacto do cultivo da cana-de-açúcar: alterações no albedo e liberação de energia radiativa através das queimadas. In: SIMPÓSIO BRASILEIRO DE SENSORIAMENTO REMOTO, 14, 2009, Natal. Anais. São José dos Campos, INPE, 2009. p. 325-332. Disponível em:

<http://marte.dpi.inpe.br/col/dpi.inpe.br/sbsr@80/2008/11.18.00.30/doc/325-332.pdf> .Acesso em 16 fevereiro. 2014.

PETRONE, M. T. S. Lavoura canavieira em São Paulo: expansão e declínio (1765-1851). São Paulo: Difusão Européia do Livro, 1968.

PIMENTEL, D.; PATZEK, T. Ethanol Production: Energy and Economic Issues Related to U.S and Brazilian Sugarcane. Natural Resources Research, v 16, n. 3, p. 235-242, 21 ago.2007.

PRADO JR., C. História Econômica do Brasil. São Paulo: Brasiliense,. 230 p. 1976

QUEDA, O. A intervenção do estado e a agroindústria açucareira paulista. Piracicaba: Tese de Doutorado (ESALQ/USP), 1972.

REGO, M. T. R. Proálcool na região de Araçatuba: o doce fel do binômio cana-boi. São Paulo: Tese de Doutorado/Universidade de São Paulo, 1990.

ROMANOWICZ, A. A.; VANCLOOSTER, M.; ROUNSEVELL, M.; LA JUNESSE, I. Sensitivity of the SWAT model to the soil and land use data parametrisation: a case study in the Thyle catchment, Belgium. Ecological Modelling, n 187, p. 27-39. 2005. 
RUDORFF, B.F.T.; AGUIAR, D.A.; SILVA, W.F.; SUGAWARA, L.M.; ADAMI, M.; MOREIRA, M.A. Studies on the Rapid Expansion of Sugarcane for Ethanol Production in São Paulo State (Brazil) Using Landsat Data. Remote Sens., 2, 1057-1076. 2010.

SAMPAIO, M. A. P. Aceleração do tempo e encurtamento das distâncias - o histórico papel das técnicas no processo de interiorização e modernização da canavicultura paulista: séculos XVI a XXI. Dissertação de Mestrado. DG. FFLCH. USP. São Paulo, 2010.

SANTOS C. N. El Niño e La Niña e a Erosividade das chuvas no Estado do Rio Grande do Sul. Tese de doutorado. Universidade Federal de Pelotas, 138p. 2008.

SANTOS, I. dos. (Organizador). Hidrometria Aplicada, ed. il. Color.cm. Curitiba, 372 p. 2001.

SANTOS, L. Doce e amargo açúcar: Concentração de renda e relações de trabalhos na produção agroindustrial canavieira do Brasil. Revista Crase.edu. $\mathrm{N}^{\circ}$ 01, Vol.01. 2010.

SÃO PAULO. Governo do Estado de São Paulo. | Lei no 11.241, de 19 de setembro de 2002. Disponível em: <http://governo-sp.jusbrasil.com.br/legislacao/94008/lei-11241-02> Acesso em: 20 Fev.2014.

SARTORI, A. Avaliação da classificação hidrológica do solo para determinação do excesso de chuva do método do serviço de conservação do solo dos Estados Unidos. Dissertação de Mestrado, Instituto de Engenharia Civil, Universidade de Campinas. 159p, 2004.

SCHULTZ, G.B.; SOUZA, R.M.; SANTOS, I. Capítulo 19: Simulação da produção e transporte de sedimentos com o modelo SWAT: Aplicação na Bacia do Altíssimo Rio Negro. Livro: Engenharia de Sedimentos na busca de soluções para problemas de erosão e assoreamento / Associação Brasileira de Recursos Hídricos; organizadores: Jorge Enoch Furquim Weneck Lima e Walszon Terllizzie Araújo Lopes. - Brasília, 2011.

SHARPLEY, A.N.; WILLIAMS, J.R. eds. 1990. EPIC-- Erosion/Productivity Impact Calculator: 1. Model Documentation. U.S. Dept. Agric. Tech. Bull. No. 1768.

SILVA,F.G.B, MINOTTI, R.T, LOMBARDI NETO, F.,PRIMAVESI, O., CRESTANA,S. Previsão da perda de solo na Fazenda Canchim - SP (EMBRAPA) utilizando 
geoprocessamento e o USLE 2D. Revista de Engenharia Sanitária e Ambiental, v.15 n.2, pag. 141-148, 2010.

SILVA M.A.S.; GRIEBELER N.P.; BORGES L.C.. Uso de vinhaça e impactos nas propriedades do solo e lençol freático. Engenharia Agrícola e Ambiental, Campina Grande, 11(1):108-114. 2007.

SILVA, A.M.; RANZINI, M.; GUANDIQUE, M.E.G.; ARCOVA, F.C.S.; DE CICCO, V. Estudo integrado do processo erosivo numa microbacia experimental localizada no município de Cunha - SP. Geociências, v.24, p.43-53, 2005.

SILVA, A. M.; SCHULZ, H. E.; CAMARGO, P. B. Erosão e Hidrossedimentologia em Bacias Hidrográficas. Editora RIMA. São Carlos, SP, 2003. 140p. 2003.

SILVA, F. G. B.; MINOTTI, R. T.; NETO, F. L.; CRESTANA, S. Previsão da perda de solo na Fazenda Canchim - SP (EMBRAPA) utilizando geoprocessamento e o USLE 2D. Eng Sanit Ambient. v.15, n.2, p. 141-148. 2010.

SIMÕES, S.J.C.; COIADO, E.M. Métodos de Estimativa da Produção de Sedimentos em Pequenas Bacias Hidrográficas, in: Hidrologia Aplicada à Gestão de Pequenas Bacias Hidrográficas. Org. por De PAIVA, J.B.D.; De PAIVA, E.M.C.D., Porto Alegre: ABRH. p. 365-394, 2001.

SINGH, P.K.; BHUNYA, P.K.; MISHRA, S.K.; CHAUBE, U.C. A sediment graph model based on SCS-CN method. Journal of Hydrology. 349, pp. 244 - 255, 2008.

SMEETS, E. JUNGINGER, M.; FAAIJ, A.; WALTER, A.; DOLZAN, P. Sustainability of Brazilian bio-ethanol. Campinas: UNICAMP, 2006. 136. (Relatório de pesquisa - NWS-E2006-2010). Disponível

em:

<http://www.globalbioenergy.org/uploads/media/0608_SenterNovem_Sustainability_of_Bra zilian_bioethanol.pdf> Acesso em: 14 Jan. 2014.

SOUSA, G. B.; MARTINS FILHO, M. V.; MATIAS, S. S. R. Perdas de solo, matéria orgânica e nutrientes por erosão hídrica em uma vertente coberta com diferentes quantidades de palha de cana-de-açúcar em Guariba - SP. Engenharia Agrícola, Jaboticabal. vol.32, no.3, p.490-500. 2012. 
SPAROVEK, G.; SCHNUG, E. Soil tillage and precision agriculture: A theoretical case study for soil erosion control in Brazilian sugar cane production. Soil and Tillage Research, v. 61, p. 47-54. 2001.

STRAUCH, M.; BERNHOFER, C.; KOIDE, S.; VOLK, M.; LORZ, C.; MAKESCHIN, F. Using precipitation data ensemble for uncertainty analysis in SWAT streamflow simulation. J. Hydrol., 414-415 , pp. 413-424, 2012.

SWAT: Soil and Water Assessment Tool. 2014 < http://SWAT.tamu.edu/software//> Acesso em: 20 jan. 2014.

SZMRECSÁNYI, T. J. M. K. O Planejamento na Agroindústria Canavieira no Brasil. São Paulo: Hucitec. 1979.

TAYLOR. S.A.; ASHCROFT, G.L. Physical edaphology: the physics of irrigated and non-irrigated soils, W.H.Freeman and Company, San Francisco, CA. 1972.

TIM, U.S. Emerging Technologies for hydrologic and water quality modeling research. Transactions of the ASAE, v.39, n. 20, p. 465-476, 1996.

TUCCI, C. E. M. Modelos Hidrológicos. Porto alegre - RS. Ed. Universidade UFRGS. Associação Brasileira de Recursos Hídricos. 652p. 2001.

TUCCI, C. E. M. Modelos Hidrológicos. 2. ed. Porto Alegre: Editora da UFRGS, 678 p. 2005.

UNICA. União da Indústria de Cana-de-Açúcar. 2014 <http://www.unicadata.com.br/historico-de-area-ibge.php?idMn=33\&tipoHistorico=5> Acesso em : 10 jan. 2014.

VIEIRA, M. C. A.; LIMA, J. F.; BRAGA, N. M. Setor Sucroalcooleiro Brasileiro: evolução e perspectivas. Rio de Janeiro: BNDES, Jun, 2007. Disponível em: <http://www.bndes.gov.br/SiteBNDES/export/sites/default/bndes_pt/Galerias/Arquivos/conhe cimento/liv_perspectivas/07>. Acesso em: 27. jan. 2014. 
VILlELA, J. M.; ARROIO JUNIOR, P. P.; GALHARTE, C. A.; CRESTANA, S.; MAUAD F. F. Simulação da Produção de Sedimentos na Bacia do Rio do Quilombo. In: Simpósio Nacional de Instrumentação Agropecuária, São Carlos: Embrapa, 2014.

WILLIAMS, J. R. Sediment-yield prediction with Universal Equation using runoff energy factor. In: Present and prospective technology for predicting sediment yield and sources. Oxford: USDA. ARS-S-40, p.244-252. 1975.

WILLIAMS, G. P. Sediment concentration versus water discharge during single hydrologic events in rivers. J. Hydrol. 111 (1-4), pp. 89-106, 1989.

WISCHMEIER, W. H.; SMITH, D. D. Predicting rainfall erosion losses from cropland east of the Rocky Mountains: Guide for selection of practices for soil and water conservation. Washington: USDA, 1965. 47p. Agriculture Handbook, 282.

WOOLHISER, D. A.; SMITH, R. E.; GOODRICH, D. C. KINEROS: A Kinematic Runoff and Erosion Model: Documentation and User Manual. U. S. Department of Agriculture, Agricultural Research Service, ARS-77, 130 pp. 1990.

YANG, C. T. Sediment Transport, Theory and Practice, New York, Ed. Krieger, 396p. 1996.

YOULTON, C. Quantificação experimental da alteração no balanço hídrico e erosão em um Neossolo Quartzarênico devido à substituição de pastagem por cana-de-açúcar. 2013. 62 f. Tese (Doutorado) - Escola de Engenharia de São Carlos, Departamento de Hidráulica e Saneamento, Universidade de São Paulo, São Carlos, 2013.

ZHANG, S. Y. L.; TAIWEI, W. How land use change contributes to reducing soil erosion in the Jialing River Basin, China. Agricultural Water Management 133 6, 2014. 


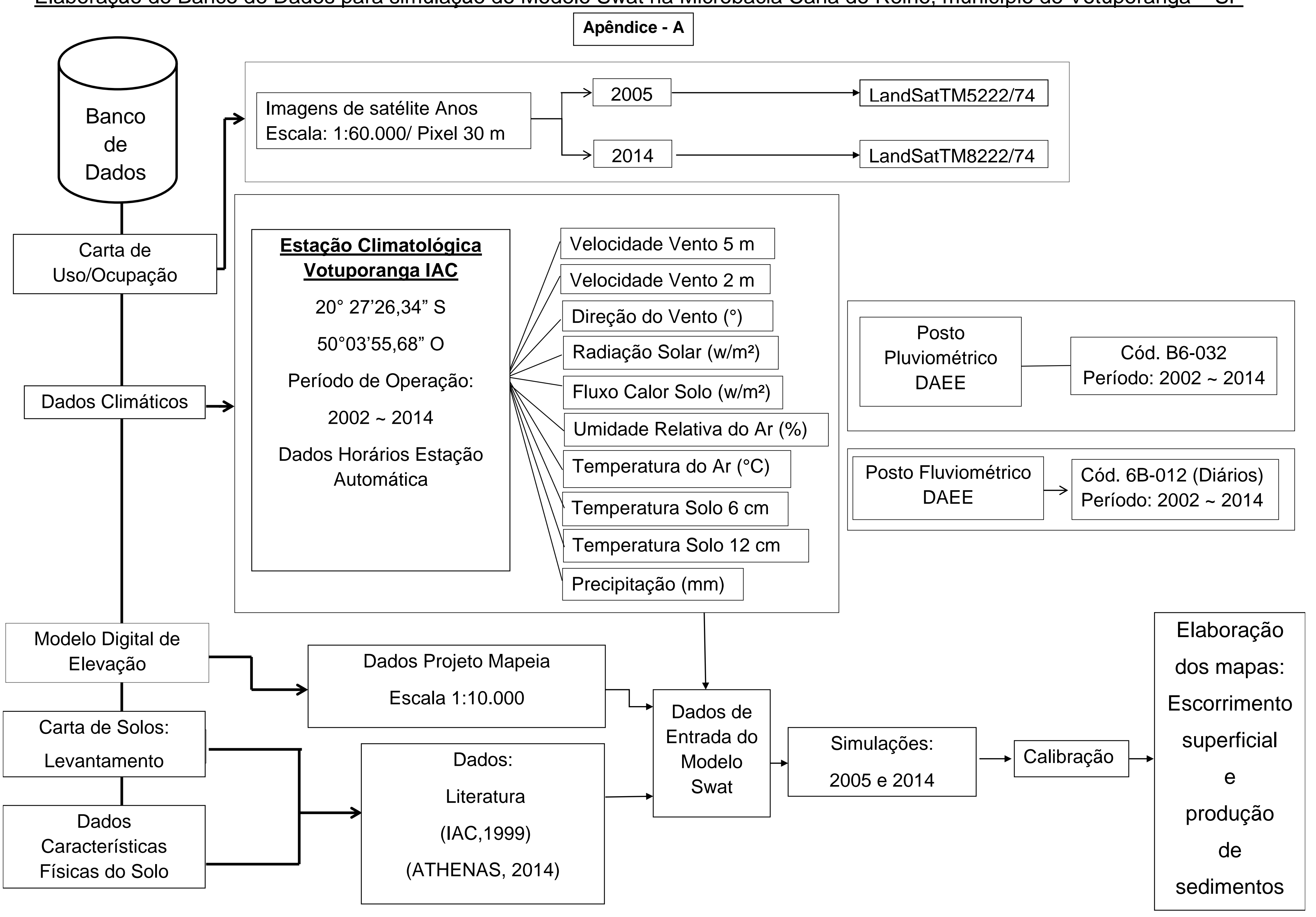


ATHENAS Consultoria Agrícola e Laboratório Ltda.

Av. Carlos Berchieri, 2271, Cidade Jardim - Jaboticabal-SP Cep: 14.890-400 Fone/Fax: (16)3202-1872

E-mail: athenas@athenasagricola.com.br

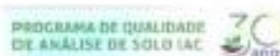

A. uska rectiven
ANEXO - I

\section{Entrada: 16/10/2014}

\begin{tabular}{|c|c|c|c|c|c|c|c|c|c|c|c|c|c|c|}
\hline \multicolumn{4}{|c|}{ AMOSTRA } & \multicolumn{11}{|c|}{ ANALISE FISICA DO SOLO } \\
\hline \multirow{2}{*}{ Lab. } & \multicolumn{3}{|c|}{ Cliente } & \multirow{2}{*}{ ARGILA } & \multirow{2}{*}{ SILTE } & \multicolumn{6}{|c|}{ AREIA } & \multirow{2}{*}{\begin{tabular}{|c|} 
Argila \\
dispersa em \\
água
\end{tabular}} & \multirow{2}{*}{$\begin{array}{c}\text { Grau } \\
\text { de } \\
\text { Floculação }\end{array}$} & \multirow{2}{*}{$\begin{array}{c}\text { Grau } \\
\text { de } \\
\text { Dispersảo }\end{array}$} \\
\hline & Propriedade & Talhão & Profundidade & & & Total & AMG & AG & AM & AF & AMF & & & \\
\hline 105538 & $\mathrm{X}: 604405,595985 \_Y: 7729604,5784$ & 1 & $0-20$ & 18 & 5 & 78 & - & 3 & - & 75 & - & - & - & - \\
\hline 105539 & $X: 604405,595985, Y: 7729604,5784$ & 1 & $20-40$ & 18 & 2 & 81 & $=$ & 3 & - & 78 & - & - & - & - \\
\hline 105540 & $\mathrm{X}: 604405,595985, Y: 7729604,5784$ & 1 & $80-100$ & 20 & 3 & 77 & - & 1 & - & 75 & - & - & - & - \\
\hline 105541 & $\mathrm{X}: 606339,468045, Y: 7731986,25234$ & 2 & $0-20$ & 10 & 8 & 82 & - & 3 & - & 80 & - & - & - & - \\
\hline 105542 & $\mathrm{X}: 606339,468045$ YY:7731986,25234 & 2 & $20-40$ & 17 & 5 & 77 & - & 1 & - & 76 & - & - & - & - \\
\hline 105543 & $\mathrm{X}: 606339,468045$ Y Y:7731986,25234 & 2 & $80-100$ & 17 & 6 & 77 & - & 1 & - & 76 & - & - & - & - \\
\hline 105544 & $X \cdot 608565,074737, Y: 7730952,26522$ & 3 & $0-20$ & 10 & 9 & 81 & - & 3 & - & 79 & - & - & - & - \\
\hline 105545 & $X: 608565,074737, Y: 7730952,26522$ & 3 & $20-40$ & 15 & 6 & 79 & - & 3 & - & 76 & - & - & - & - \\
\hline 105546 & $X: 608565,074737, Y: 7730952,26522$ & 3 & $80-100$ & 25 & 4 & 71 & - & 1 & - & 70 & - & - & - & - \\
\hline 105547 & $X: 609813,556872, Y: 7732406,44649$ & 4 & $0-20$ & 15 & 7 & 78 & - & 4 & - & 74 & - & - & - & - \\
\hline 105548 & $\mathrm{X}: 609813,556872 \_$Y:7732406,44649 & 4 & $20-40$ & 15 & 8 & 77 & - & 2 & - & 75 & - & - & - & - \\
\hline 105549 & 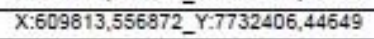 & 4 & $80-100$ & 23 & 6 & 72 & - & 2 & - & 70 & - & - & - & - \\
\hline 105550 & $\mathrm{X}: 608014,380874$ YY:7733298,87595 & 5 & $0-20$ & 17 & 3 & 79 & - & 2 & - & 78 & - & - & - & - \\
\hline 105551 & $\mathrm{X}: 608014,380874$ YY:7733298,87595 & 5 & $20-40$ & 20 & 4 & 76 & - & 1 & - & 74 & - & - & - & - \\
\hline 105552 & $\mathrm{X}: 608014,380874$ YY:7733298,87595 & 5 & $80-100$ & 27 & 6 & 66 & - & 1 & - & 66 & - & - & - & - \\
\hline 105553 & $\mathrm{X}: 609781,210172, Y=7733739,30726$ & 6 & $0-20$ & 17 & 15 & 68 & - & 2 & - & 66 & - & - & - & - \\
\hline 105554 & $\mathrm{X}: 609781,210172 \_Y: 7733739,30726$ & 6 & $20-40$ & 27 & 11 & 62 & - & 2 & - & 60 & - & - & - & - \\
\hline 105555 & $\mathrm{X}: 609781,210172 \_Y: 7733739,30726$ & 6 & $80-100$ & 40 & 10 & 50 & - & 2 & - & 48 & - & - & - & - \\
\hline 105556 & $X: 607901,15662 \_Y .7734139,84754$ & 7 & $0-20$ & 15 & 5 & 80 & - & 2 & - & 78 & - & - & - & - \\
\hline 105557 & $\mathrm{X}: 607901,15662 \_\mathrm{Y}: 7734139,84754$ & 7 & $20-40$ & 18 & 2 & 80 & - & 3 & - & 78 & - & - & - & - \\
\hline 105558 & $\mathrm{X}: 607901,15662 \_Y: 7734139,84754$ & 7 & $80-100$ & 20 & 3 & 77 & - & 1 & - & 76 & - & - & - & - \\
\hline 105559 & $\mathrm{X}: 610116,120425 \_Y=7735256,58988$ & 8 & $0-20$ & 17 & 7 & 76 & - & 4 & - & 71 & - & - & - & - \\
\hline 105560 & $X: 610116,120425$ Y Y 7735256,58988 & 8 & $20-40$ & 16 & 6 & 78 & - & 3 & - & 74 & - & - & - & - \\
\hline 105561 & $\mathrm{X}: 610116,120425 \_Y: 7735256,58986$ & 8 & $80-100$ & 22 & 7 & 70 & - & 2 & - & 68 & - & - & - & - \\
\hline 105562 & X:607970,3453_Y:7736537,17577 & 9 & $0-20$ & 15 & 5 & 80 & - & 4 & - & 76 & - & - & - & - \\
\hline 105563 & $X: 607970,3453 \_Y: 7736537,17577$ & 9 & $20-40$ & 21 & 3 & 76 & - & 5 & - & 71 & - & - & - & - \\
\hline 105564 & $\mathrm{X}: 607970,34533_{3} Y: 7736537,17577$ & 9 & $80-100$ & 22 & 4 & 73 & - & 4 & - & 69 & - & - & - & - \\
\hline 105565 & $\mathrm{X}: 610675,212585$ YY:7737644,96195 & 10 & $0-20$ & 12 & 4 & 84 & - & 8 & - & 76 & - & - & - & - \\
\hline 105566 & $\mathrm{X}: 610675,212585$ YY:7737644,96195 & 10 & $20-40$ & 17 & 5 & 77 & - & 3 & - & 74 & - & - & - & - \\
\hline 105567 & $\mathrm{X}: 610675,212585$ YY:7737644,96195 & 10 & $80-100$ & 22 & 6 & 72 & - & 3 & - & 69 & - & - & - & - \\
\hline & & & mutho gr & arel: & & & Ela fina & 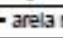 & & & & & & \\
\hline
\end{tabular}

Eng ${ }^{\circ}$ Agr" Dr. Diogo Mazza Barbieri 
ATHENAS Consultoria Agrícola e Laboratório

ANEXO - II

Av. Carlos Berchieri, 2271, Cidade Jardim - Jaboticabal-SP Cep: 14.890-400 Fone/Fax: (16)3202-1872

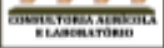

E-mail: athenas@athenasagricola.com.br

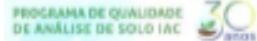

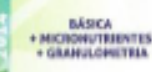

Cliente: JOÃO - USP - SÃO CARLOS

Entrada: $16 / 10 / 2014$

Emissão Resultados: 23/10/2014

Total de amostras: 30

Página

\begin{tabular}{|c|c|c|c|c|c|c|c|c|c|c|c|c|c|c|c|c|c|}
\hline \multicolumn{4}{|c|}{ AMOSTRA } & \multicolumn{14}{|c|}{ ANALISE QUIMMICA DO SOLO } \\
\hline \multirow{3}{*}{ Lab. } & \multicolumn{3}{|c|}{ Cliente } & \multirow{3}{*}{$\frac{\mathrm{pH}}{\mathrm{CaCl}_{2}}$} & \multirow{2}{*}{ M.o. } & $P$ & $P$ & \multirow{2}{*}{$\mathbf{s}$} & \multirow{2}{*}{$\mathrm{Ca}$} & \multirow{2}{*}{$\mathrm{Mg}$} & \multirow{2}{*}{$\mathbf{K}$} & \multirow{2}{*}{ Al } & \multirow{2}{*}{$\begin{array}{l}\mathrm{H}+\mathrm{Al} \\
\text { SMP }\end{array}$} & \multirow{2}{*}{\begin{tabular}{|c} 
Soma \\
Bases \\
S.B.
\end{tabular}} & \multirow{2}{*}{$\mathrm{CTC}$} & \multirow{2}{*}{$\begin{array}{c}\text { Sat. } \\
\text { Bases }\end{array}$} & \multirow{2}{*}{$\begin{array}{c}\text { Sat. } \\
\text { Al }\end{array}$} \\
\hline & \multirow[b]{2}{*}{ Propriedade } & & \multirow[b]{2}{*}{ Profundidade } & & & Resina & Menllich & & & & & & & & & & \\
\hline & & Talhäo & & & $\mathrm{g} \mathrm{dm}^{-3}$ & \multicolumn{3}{|c|}{$-\mathrm{mg} \mathrm{dm}^{-3}$} & \multicolumn{7}{|c|}{1} & V\% & $\mathrm{m} \%$ \\
\hline 105538 & X;604405,595985_Y:7729604,5784 & 1 & $0-20$ & 4,8 & 22 & 13 & - & 3 & 16 & 5 & 2,0 & 0 & 24 & 23,0 & 47,0 & 49 & 0 \\
\hline 105539 & X:604405,595985_Y.7729604,5784 & 1 & $20-40$ & 5,3 & 10 & 9 & - & 3 & 22 & 10 & 1,2 & 0 & 18 & 33,2 & 51,2 & 65 & 0 \\
\hline 105540 & X:604405,595985_Y.7729604,5784 & 1 & $80-100$ & 4,6 & 4 & 6 & - & 19 & 12 & 4 & 0,5 & 1 & 18 & 16,5 & 34,5 & 48 & 6 \\
\hline 105541 & $\mathrm{X}: 606339,468045 \_\mathrm{Y}: 7731986,25234$ & 2 & $0-20$ & 4,9 & 11 & 7 & - & 4 & 19 & 5 & 1,5 & 0 & 89 & 25,5 & 114,5 & 22 & 0 \\
\hline 105542 & X:606339,468045_Y:7731986,25234 & 2 & $20-40$ & 5,0 & 8 & 13 & - & 3 & 25 & 6 & 0,9 & 1 & 17 & 31,9 & 48,9 & 65 & 3 \\
\hline 105543 & $\mathrm{X}: 606339,468045 \_\mathrm{Y}: 7731986,25234$ & 2 & $80-100$ & 5,1 & 3 & 8 & - & 10 & 18 & 4 & 0,4 & 0 & 24 & 22,4 & 46,4 & 48 & 0 \\
\hline 105544 & $\mathrm{X}: 608565,074737 \_\mathrm{Y}: 7730952,26522$ & 3 & $0-20$ & 6,0 & 11 & 10 & - & 3 & 33 & 15 & 3,1 & 0 & 23 & 51,1 & 74,1 & 69 & 0 \\
\hline 105545 & X:608565,074737_Y:7730952,26522 & 3 & $20-40$ & 5,5 & 10 & 7 & - & 6 & 22 & 12 & 3,7 & 0 & 16 & 37,7 & 53,7 & 70 & 0 \\
\hline 105546 & $\mathrm{X:608565,074737 \_ Y:7730952,26522}$ & 3 & $80-100$ & 5,6 & 5 & 6 & - & 8 & 32 & 13 & 1,5 & 0 & 14 & 46,5 & 60,5 & 77 & 0 \\
\hline 105547 & $\mathrm{X}: 609813,556872 \_Y: 7732406,44649$ & 4 & $0-20$ & 6,1 & 22 & 77 & - & 7 & 38 & 21 & 6,5 & 0 & 12 & 65,5 & 77,5 & 85 & 0 \\
\hline 105548 & X:609813,556872_Y:7732406,44649 & 4 & $20-40$ & 5,8 & 13 & 27 & - & 5 & 27 & 16 & 6,0 & 0 & 13 & 49,0 & 62,0 & 79 & 0 \\
\hline 105549 & $\mathrm{X:609813,556872 \_ Y:7732406,44649}$ & 4 & $80-100$ & 5,6 & 5 & 9 & - & 12 & 26 & 9 & 4,4 & 0 & 14 & 39,4 & 53,4 & 74 & 0 \\
\hline 105550 & $\mathrm{X:608014,380874 \_ Y:7733298,87595}$ & 5 & $0-20$ & 5,3 & 15 & 13 & - & 7 & 32 & 13 & 3,8 & 0 & 16 & 48,8 & 64,8 & 75 & 0 \\
\hline 105551 & X:608014,380874_Y:7733296,87595 & 5 & $20-40$ & 5,3 & 13 & 11 & - & 8 & 33 & 18 & 2,9 & 0 & 25 & 53,9 & 78,9 & 68 & 0 \\
\hline 105552 & $X: 608014,380874$ _Y:7733296,87595 & 5 & $80-100$ & 4,5 & 6 & 6 & - & 4 & 6 & 4 & 1,7 & 6 & 25 & 11,7 & 36,7 & 32 & 34 \\
\hline 105553 & 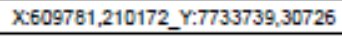 & 6 & $0-20$ & 5,4 & 18 & 16 & - & 9 & 45 & 16 & 5,2 & 1 & 29 & 66,2 & 95,2 & 70 & 1 \\
\hline 105554 & X:609781,210172_Y:7733739,30726 & 6 & $20-40$ & 5,6 & 14 & 15 & - & 8 & 52 & 18 & 4,6 & 0 & 40 & 74,6 & 114,6 & 65 & 0 \\
\hline 105555 & X:609781,210172_Y:77337339,30726 & 6 & $80-100$ & 5,6 & 5 & 6 & - & 31 & 32 & 15 & 2,1 & 0 & 18 & 49,1 & 67,1 & 73 & 0 \\
\hline 105556 & X:607901,15662_Y:77344139,84754 & 7 & $0-20$ & 5,9 & 10 & 9 & - & 3 & 21 & 11 & 1,8 & 0 & 12 & 33,8 & 45,8 & 74 & 0 \\
\hline 105557 & X:607901,15662_Y:77734139,84754 & 7 & $20-40$ & 6,1 & 11 & 8 & - & 3 & 25 & 13 & 1,6 & 0 & 11 & 39,6 & 50,6 & 78 & 0 \\
\hline 105558 & X:607901,15662_Y:77344139,84754 & 7 & $80-100$ & 4,5 & 4 & 6 & - & 3 & 9 & 4 & 0,6 & 2 & 20 & 13,6 & 33,6 & 40 & 13 \\
\hline 105559 & $\mathrm{X}: 610116,120425 \_Y: 7735256,58968$ & 8 & $0-20$ & 5,0 & 19 & 12 & - & 4 & 33 & 13 & 3,3 & 0 & 27 & 49,3 & 76,3 & 65 & 0 \\
\hline 105560 & $\mathrm{X:610116,120425 \_ Y:7735256,58968}$ & 8 & $20-40$ & 5,2 & 13 & 8 & - & 3 & 34 & 12 & 1,9 & 0 & 30 & 47,9 & 77,9 & 61 & 0 \\
\hline 105561 & $X: 610116,120425 \_Y: 7735256,58968$ & 8 & $80-100$ & 5,2 & 4 & 7 & - & 6 & 24 & 7 & 1,2 & 0 & 17 & 32,2 & 49,2 & 65 & 0 \\
\hline 105562 & X:607970,3453_Y:7736537,17577 & 9 & $0-20$ & 4,1 & 13 & 11 & - & 3 & 17 & 9 & 3,6 & 3 & 46 & 29,6 & 75,6 & 39 & 9 \\
\hline 105563 & X:607970,3453_Y:7736537,17577 & 9 & $20-40$ & 4,3 & 8 & 5 & - & 3 & 17 & 6 & 2,3 & 4 & 52 & 25,3 & 77,3 & 33 & 14 \\
\hline 105564 & X:607970,3453_Y.7736537,17577 & 9 & $80-100$ & 5,4 & 5 & 4 & - & 6 & 22 & 8 & 0,9 & 0 & 14 & 30,9 & 44,9 & 69 & 0 \\
\hline 105565 & X:610675,212585_Y:7737644,96195 & 10 & $0-20$ & 5,4 & 19 & 10 & - & 4 & 25 & 17 & 1,4 & 0 & 24 & 43,4 & 67,4 & 64 & 0 \\
\hline 105566 & $\mathrm{X}: 610675,212585$ _Y:7737644,96195 & 10 & $20-40$ & 4,8 & 14 & 8 & - & 3 & 18 & 6 & 0,9 & 3 & 33 & 24,9 & 57,9 & 43 & 11 \\
\hline 105567 & $\mathrm{X:610675,212585 \_ Y:7737644,96195}$ & 10 & $80-100$ & 5,5 & 5 & 6 & - & 4 & 21 & 8 & 1,0 & 0 & 15 & 30,0 & 45,0 & 67 & 0 \\
\hline
\end{tabular}

Eng ${ }^{\circ}$ Agr' Dr. Diogo Mazza Barbieri 